TEXT Vol 19 Special Issue No 30 (October 2015) Creative Writing as Research IV

\title{
Contents Part 2
}

- Jeri Kroll, Birth page 2

- Anthony Lawrence, Ghazal page 10

- Jarryd Luke, The Carillon page 13

- Gay Lynch, The speculative fiction umbrella page 22

- Nollie Nahrung, Little snatches: becoming-girl, becoming-woman through the touching glass page 29

- Camilla Nelson, What you don't know [extract] page 36

- Gail Pittaway, Three physical conceits page 44

- Julia Prendergast, Everything that matters is silvery white page 49

- Karina Quinn, How to disappear in your name page 58

- Francesca Rendle-Short, Parsing the aside (the poetics of immersion and patience as dialogue) page 72

- Kate Ryan, The mourning dress page 83

- Nike Sulway, Paper boats page 101

- Julienne van Loon, The fifth story page 112

- Various, At land's edge: three collaborative poems page 117

- Ross Watkins, You see now page 124 


\section{Flinders University}

\section{Jeri Kroll}

\section{Birth}

\section{Biographical note:}

Professor Jeri Kroll is Dean of Graduate Research at Flinders University and former President of the Australasian Association of Writing Programs. She has published twenty-five titles for adults and young people. Criticism includes Research Methods in Creative Writing (Palgrave Macmillan, 2013). Workshopping the Heart: New and Selected Poems (Wakefield Press, 2013) and a verse novel, Vanishing Point (Puncher and Wattman, 2015), are recent books. A MainStage production of Vanishing Point was held at George Washington University in October 2014. The play was a winner in the $47^{\text {th }}$ Kennedy Center American College Theatre Festival and produced in January 2015 in Ohio. Vanishing Point was short-listed in the 2015 Queensland Literary Awards (Young Adult Books category).

\section{Keywords:}

Creative writing - sexual abuse - equine-facilitated psychotherapy - therapeutic metaphors - naturalism 
As the ute sped up the main road towards the hills, Megan noticed that the sun, which had been midway down the sky when they'd gone inside the pub, had now plumped into a chrome ball, which in a few minutes began to flatten, turning the horizon the colour of maize. By the time they reached the home yard, a soft glow flickered through the trees.

'I'll go change,' Megan called to Josh, who was heading towards the stables to mix Phoenix's dinner.

Standing in a corner, the mare stared at nothing, she could almost have been dozing, but her ears and a slight movement of her head showed that she was aware of Josh passing. Megan slammed the screen door five minutes later, dressed in a faded blue tracksuit, with her bushy hair captured by a band so that it hung down her back, Josh had once said, like a vixen's tail. Did that make her threatening, Megan had wondered? She liked the idea that she might be seen as hunter rather than prey. She shivered, even though it was mild, remembering.

Josh was just coming out of the stables, lugging a bucket filled with a damp mixture of chaff and pellets. He bent to Phoenix's rubber feed bin on the other side of the yard from where the mare stood and shook out the bucket. Megan walked across from the house and noticed at once that Phoenix hadn't moved and dinner had been served, strange from a horse that always seemed to think a famine was imminent. Phoenix held up her tail as if she were going to pee but remained motionless. Then she took three steps into the yard's centre and stopped to spread her back legs. Josh had already retreated into the shadows. Megan could hear him shifting bales, getting ready to chuck hay to the other horses. She rushed over and climbed through the rails into the yard.

The stillness was eerie, the mare frozen as if she were the embodiment of one frame of a picture of herself. Then Megan sensed movement. A pale milky blue balloon began protruding from the mare's back end. At first what it might be didn't register, because dusk hadn't yet washed over the golden sky. Megan crept around so as not to startle her, and stood directly behind. There it was, a bladder stretched into the shape of a watermelon slice, growing slowly out of her vulva.

Josh emerged from the dark of the stables, pushing a rusty wheelbarrow that made more noise than the magpies' atonal calls. 'Look,' Megan whispered. 'Come here.'

Josh dropped the handles and within three strides stood next to Megan. They both watched as the mare rocked once or twice and then folded her legs so she could lie down on her side. As if someone hadn't finished fashioning a balloon animal, the sac stretched and changed shape into a translucent pearl blue tube, which was being squeezed out. 'Those must be the legs,' Josh said, his voice hoarse.

'What's that?' Megan pointed to something near the front the size of a cup.

Josh bent down so he was squatting, but he didn't move closer, studying the sac. 'It's got to be the nose. Yes!' He raised his voice and then lowered it. 'That's the perfect position. The head's folded down on the legs, because the foal needs to dive out.' 
The breeze, which had hardly been a shuffle through the gums, dropped altogether. Light above the stables blurred into the colour of ghee, slick as the membrane that encased the legs. Phoenix began to grunt rhythmically, her round body pushing. The legs slid forward a few millimetres. Megan squatted next to Josh, so that they faced one another, then crept closer to touch the wet sac. Phoenix pushed again, but it didn't move much more.

After five minutes the mare rolled sideways as if she were about to rise, but instead that rocking energised her. She groaned, huffed and strained so that the legs inched forward. Josh knelt behind Phoenix and the next time she pushed he began to tug. 'This little one doesn't want to leave its comfort zone. We might have to coax it.'

Megan felt the need to touch again but was afraid to interfere. The mare rested, then the rolling recommenced accompanied by her rhythmic breath. All at once the head fully appeared, slim and hooded, and then with another few pushes, with blood pooling in the bottom of the sac, three-quarters of a foal slid out. The sac broke on its own, pricked by the hoofs, and Megan reached to pull away the rubbery tissue.

'The back legs are still inside,' Josh said. 'Be patient.'

'I hate patient,' Megan whispered.

Phoenix lay there, seemingly exhausted. Is this how a first-time mother was supposed to behave? She puffed twice, but didn't stir. Megan leaned over again and began to tug gently, although the mare wasn't straining. But she was afraid for her, for both of them. 'Will she roll onto the foal if she tries to get up?'

'I have no idea,' Josh said. 'But it's alive - and chestnut.' The foal snuffled and Josh ran his fingers over its face, wiping away the sticky birth sac, which came off in strips, as if he were peeling the skin from a hardboiled egg. 'You clear the mouth and nose.'

Megan inserted her fingers between its soft lips and the foal blew out, shaking its head at the invasion, sounding like a baby just coming down with a cold. It was such a funny-looking pile with an oversized head bobbing on top and front legs splayed out, trying to balance, half stuck in the mare. It seemed askew and Megan wondered if it had dislocated any bones. Then Phoenix took over and grunted once more. This time Josh pulled and the rest of the back legs glided out. He peeled off the remnants of the sac, as if the baby were an orange. Finally, it lay whole on the earth it would run upon for years, truly itself, free of its mother.

'If we keep touching it now, it won't fear humans,' Josh whispered to Megan. 'Here.' He reached for her hand, and together they rubbed its ears, across its eyes, fringed by feathery lashes, its forehead, mouth and chin, with whiskers fine as a cat's. They stroked the foal and every so often their hands would meet and cross, Josh's rough palm gliding across the back of Megan's fingers, as they let themselves feel the pleasure of a warm body. Then Megan massaged its shoulders, back and belly. Finally she came to the legs, noticing how slender they were, bones beneath the fur like the stakes they used to prop up saplings. When she reached the pliable hooves, she felt bits of placenta still stuck to them, as if the foal had walked through gum. But they were perfectly shaped, almost dainty. 
'Welcome to the world, little one,' Josh said as he held its head up to him, his voice wavering.

'What is it?' Megan sat back on her haunches, breaking the trance they'd fallen into.

'Good question. I haven't even looked.' Josh sounded as if that were the funniest thing he'd said in a long time. He rolled the foal over a few degrees so he could peer at its underside and felt with his hand. 'It's a filly, I reckon.'

Josh sounded undecided to Megan, but he couldn't be about the sex, could he?

'Well is she or not?'

Josh snorted and patted the filly's belly. 'Yeah, no doubt about it. I was just thinking that in some ways colts are easier, at least after they're gelded. A lot of competitive riders steer clear of mares.'

'Are you disappointed?' Megan couldn't believe it. How could Josh even be thinking about the future, when nothing yet - good or bad - had happened to the filly. 'But you don't even know what she'll be like. If she's anything like Phoenix...'

'Don't jump on me. I only meant that mares are prone to be moody.'

'Just mares? Did you actually say that?' Megan shook her head at Josh.

He raised his eyes and grunted, before looking directly at her. 'Okay, you've got me there. Guilty as charged.'

Finally, Megan thought, he's admitting how black he can be. But she also understood him well enough by now not to expect him to say more.

'I didn't mean she wouldn't turn out well,' Josh said, turning his attention back to the filly. 'And if she does, maybe I can breed her. There's plenty of time to see.'

Twilight had colonised the sky while they had been intent on the birth. A few stars poked through the indigo blue wash. The air began to chill off. 'We've warmed the baby some, but Phoenix needs to get up and bond with her.' Josh stood and shook his legs. 'God, I've got cramps.'

As if she'd heard him, Phoenix shifted back and forth, then struggled, half rising, finally making it to a standing position, facing away from the foal, which was still a fragile heap at her rear. She hadn't yet acknowledged her presence. Then she stretched her head around and stared, as if the filly had always been there, just one more thing that she expected in her yard, before turning back, totally calm. Now she was the one who seemed to be in a trance. Maybe she's gathering strength, Megan thought. Once she begins mothering, she won't have any rest.

Megan rose as well and bent to massage her calves.

'Feels like I've been in this position for hours.'

Phoenix turned at her voice and then wandered over to sniff the feed bin.

'Hey girl,' Megan called. 'Is dinner more important?'

'You really don't want to know the answer to that,' Josh laughed. 'It might destroy your romantic notions of motherhood.' 
'Never had those,' she shot back, shaking her head.

The mare dipped her muzzle into the chaff and shuffled the sticky mixture around, playing. Megan shoved her hands in her pockets and immediately felt the carrot she'd saved for Shine. She took it out, snapping it in half. The pop made the mare swivel towards her. Megan walked over to the foal on the ground and knelt. Phoenix turned her body away from the bin and followed, her nose twitching. As Megan stroked the foal's neck, the mare finally lowered her big head to the tangle of legs and fur. She nickered, sniffed. The foal sniffed back. Megan rose and moved out of the way. They began to blow gently on each other, touching noses and nuzzling. Then Phoenix began to lick. First the foal's head, all over - ears, muzzle, even the eyes. She made satisfied gasps, as if she were inhaling not just her smell, but also her shape.

'Clever move,' Josh said and came to put his hand on Megan's shoulder. He gave it a squeeze and left it there.

As they watched, Megan thought, that's the way she's saying to herself, 'This is my baby. She belongs to me. I belong to her.' Once Phoenix had begun she seemed to enjoy it, she licked methodically - legs, back and sides, then started once more at the head. This is a ritual they watched her perform several times over the next half hour. Neither Megan nor Josh wanted to leave, although once he darted inside the stable for a lantern so they could see the rest of the evening unfold. This was new to both of them, at least the details, and it was details that mattered. They stood transfixed, learning that lesson over and over.

Phoenix finally stopped, twisted her head and spotted what was left of the placenta, which looked like a torn plastic jacket crumpled on the earth. She swayed over, reached down, sniffing, then lapped at it before nibbling. As she moved Josh and Megan turned to each other at the same time. 'The rest of the sac's still hanging from her,' Josh said.

'What do we do?'

'Dunno. Maybe nothing yet.' He thought a moment. 'Let's see how nature takes care of it. If it's still there in a while, I might call the vet.' He checked his watch and then forgot about the time. But a while later Megan noticed that more of the rubbery membrane was hanging down from inside. Finally it simply dropped out. When it did, the mare seemed to wake. She did a one-hundred-eighty degree pivot until she was facing her baby. She dipped her nose, snuffled the last of the placenta and ate that too.

'It's nourishing,' Josh said. 'She's going to need a boost for nursing.'

Nearly an hour had passed since the birth. The foal had tried to rise several times, but her long legs kept her from balancing. She collapsed, too uncoordinated. Megan and Josh heard the horses whinnying from the other paddocks, as if they knew something had happened, but they weren't quite sure what.

'Is there anything else we need to do?' Megan asked, as she leant against the yard rail. By now, the moon had materialised low in the sky, a blurry raw pearl among evening stars like splinters of glass. 
'Actually, yes. Wait a minute.' He climbed through the fence and disappeared into the house, returning with a wad of cotton and some iodine. 'Might as well swab the umbilical stub. Just as a precaution. Here, hold this.' He pulled off a swatch of cotton, doused it with iodine and passed the bottle back to Megan. Then he bent to the foal and dabbed what looked to Megan like a broken root.

'Let's see if we can get the filly on her legs,' Josh said. 'She can't nurse if she can't balance.' Phoenix didn't worry as he knelt to clasp the foal's chest and rear, encasing her in his arms, before raising her to a standing position. Then he let go. The filly teetered and fell. Josh repeated the process but she collapsed again. Finally, after another two tries, the filly swayed but remained upright, splaying her front and back legs. Megan thought she looked like a giant spider with her plump body and thin spindles.

'She has a pretty head,' Josh said, nodding to himself. 'And she'll be taller than her mother.'

That fact, Megan saw, was going to cause problems now. The filly took a few steps towards the mare, sniffing for the right place to nurse. But she couldn't bend her neck underneath the mare's bulk at the same time without collapsing. Not yet. She wanted to suck, Megan could see, because when she walked over to help and put her hand down near the filly's head she had a go at her fingers. Then the filly tried again, pushing against Phoenix's rump, but she was too far away from the udder. Eventually, she stopped.

'She must be so tired and she hasn't had a drink,' Megan said.

'Nothing to worry about yet,' Josh answered. 'At least I don't think so.'

After a few minutes the filly ducked again towards the mare's underside and managed to grab a black leathery teat with its tantalising dot of milk.

'Mission accomplished,' Josh said. 'Let's leave them alone. Give them time to sort it out. I need a drink and we can check that everything's fine before bed.'

They walked back to the house and stepped onto the veranda, but Megan turned, not wanting to go inside. After five minutes, Phoenix headed to her feed bin, dipped her nose, swished the chaff and began gobbling. She only stopped for a moment to nicker at the filly to follow, which swayed over as if intoxicated with mare's milk. She'd already nursed once and had the taste in her mouth. She dared to put her head under the huge grey belly once more and didn't shift.

'Come on,' Josh called from the kitchen. 'You've got years to watch her yet. I've bought some decent cheeses and biscuits. Tracey gave me some of her vine leaves and I've opened a bottle of wine. We might as well celebrate. Phoenix has done a good job.'

'Oh, you haven't fed the others yet,' Megan answered, noticing the wheelbarrow at the side of the yard still heaped with hay.

'There's plenty of decent pasture. I'll chuck that to them in the morning - unless Phoenix eats it all first. I'm probably hungrier than the others right now.' 
They ate in silence, both ravenous, as if they'd been out all morning on a ride. Then they lingered over the wine, Josh explaining for the first time what he would do and when. Perhaps he'd been superstitious, didn't want to plan that far ahead until the foal's first hurdle - being born - was cleared. At ten o'clock they wandered out to the stables to make sure mother and foal were settled for the night. Josh took Megan's hand and their fingers interlaced, as if they'd always walked this way at the end of a good night.

Even before they reached the yard they could hear the horses. Josh placed his lantern on a far post so as not to startle them. Phoenix was in a corner, up against the fence, the filly parallel to her. Megan could see by her absolute stillness and the vacant expression on her face in the wash of the lantern that the foal was nursing. Then she realised what they had heard a few minutes before - the rhythmic sucking, the intake of breath, a humming that rolled up and around them in waves. As the moon and stars shifted position by degrees, or the earth itself spun away - it didn't matter which Phoenix became the still point under the sky as the breeze lifted and freshened, her great ghostly body like dusky marble in the nightglow. 


\section{Research statement}

\section{Research background}

Equine Facilitated Psychotherapy (EFP) is rooted in therapeutic practice and self-help and natural horsemanship literature. It investigates how including an equine enhances the conventional therapy of sufferers with social and psychological disorders. An emergent field relying on anecdotal reports, few case studies and small sample size, it needs rigorous research design to answer questions about why and how the horsehuman dynamic works (Fry 2013), in particular for women recovering from sexual abuse (Meinersmann et al. 2008).

\section{Research contribution}

'Birth' (novel excerpt) explores premises about psychological healing. It extends the $19^{\text {th }}$ century naturalist tradition (Campbell 2011) of Émile Zola in conceiving of the novel as laboratory that incorporates case studies, but rejects determinism. A practitioner's use of 'therapeutic metaphors' (Fry 276) helps clients to achieve insights, just as characters begin to understand themselves through textual metaphors.

\section{Research significance}

This novel examines the dynamics of healing in tandem with abused or abandoned horses acting as therapeutic mirrors and as surrogates facilitating emotional attachment. By exploring hypotheses suggested by EFP research, it raises questions that might guide future study design.

\section{Works cited}

Campbell, D 2011 'Naturalism' in PM Logan (ed) The Encyclopedia of the Novel, Blackwell Publishing, Blackwell Reference Online 1-5, at http://www.blackwellreference.com/subscriber/tocnode.html (accessed 8 April 2015)

Fry, NE 2013 'Equine-assisted therapy: an overview' in M Grassberger et al. (ed) Biotherapy History, Principles and Practice: A Practical Guide to the Diagnosis and Treatment of Disease using Living Organisms, Dordrecht: Springer Science+Business Media, 255-84

Meinersmann, KM, Bradberry, J and Roberts FB 2008 'Equine-facilitated psychotherapy with adult female survivors of abuse', Journal of Psychosocial Nursing 46 (12): 36-42 


\section{Griffith University}

\section{Anthony Lawrence}

\section{Ghazal}

\section{Biographical notes:}

Anthony Lawrence has published fourteen books of poems and a novel. His most recent collection, Signal Flare, was shortlisted for the Judith Wright Calanthe award. A new book, Wax Cathedral, is forthcoming from Pitt Street Poetry in 2016. He is the 2015 recipient of the Philip Hodgins Memorial Medal for Literature. He teaches creative writing, including writing poetry, at Griffith University, Gold Coast.

Keywords:

Creative writing - poetry - Ghazal - poetry, form - poetry, themes 
I woke to a fine sifting in the air outside my tent

where I'd set up camp, on the mend

from analgesic amendments

to a life I'd found wanting, then wanting again.

A storm was approaching in a tidal, not agrarian way.

And while it's tempting to name

my location as being where wind

is known as khamsin, chinook, simoom

I was fifty miles from Broken Hill

not high in Colarado or the Sinai, and I was clean

not working for visions

on the opiates altitude and reclusiveness.

And this was, colloquially, bull dust

coming on as a red rolling wave

throwing up leaves and sticks like birds

beaten from cover. And despite trying

to stop the storm from getting in

I could taste earth and sky in each breath.

And when the flysheet turned to a smear of blood

on a slide, I began to revise

with an abrasive, restored sense of hope

the poem I'd been breaking down for days.

Instead of lowering the worn signal-arm

of my name in the last lines, I signed off

with my father's initials, as if he'd just

passed through the tent's molecular structure

to give me the all-clear

concerning recovery, poetry and weather. 


\section{Research statement}

\section{Research background}

American poet Jim Harrison observed that the Ghazal's ancient form made it ideal for exploring contemporary issues. He said his expression found form in the Ghazal to define 'whatever aspect of our life now that seemed to want to enter my field of vision' (1971: 26). The Ghazal's themes were traditionally specified - love, separation, carnality and mysticism - but these are also key themes in contemporary verse.

\section{Research contribution}

Central to my ongoing contribution to research into poetics and the writing of poetry is an engagement with various forms and styles, in which I offer contemporary alternatives to traditional modes. 'Ghazal' is both a commentary on a traditional form and a reworking of it. In Beautiful \& Pointless, critic and poet David Orr discusses style, shape and form, and identifies "some distinct, often nameless category called " $X$ " that we think (and believe the poet thinks) we're supposed to recognise as being associated with the poem' (2011: 70). My poem 'Ghazal' works to suggest, rather than name directly, this nameless category (or aspect) of formal poetry.

\section{Research significance}

Both my most recent, Signal Flare (2013), and forthcoming collection, Wax Cathedral (2016), contain poems that, like 'Ghazal', utilise aspects of, or embrace fully, traditional styles and forms (iambic pentameter, sonnets, villanelles, ghazals) and imbue them with contemporary themes. In this poem, by utilising and referencing the Ghazal, but not actually writing in the form, there is a potent sense of loss of intimacy with the form, the self and family. By citing the form's potential impact in the poem's last lines, the expectation the title creates is thwarted and attention diverted to the poem's inner workings.

\section{Works cited}

Harrison, J 1971 Outlyer and Ghazals New York: Simon and Schuster

Lawrence, A 2013 Signal Flare Glebe, NSW: Puncher \& Wattmann

Orr, D 2011 Beautiful \& Pointless New York: Harper Collins 


\title{
Queensland University of Technology
}

\author{
Jarryd Luke
}

The Carillon

Biographical note:

Jarryd Luke has a $\mathrm{PhD}$ in creative writing from the Queensland University of Technology, and in 2011 he was shortlisted in the QUT Postgraduate Writing Prize and the State Library of Queensland Young Writers Award. His manuscript was shortlisted in the Emerging Author category of the 2013 Queensland Literary Awards. He has been published in The Lifted Brow, TEXT, M/C Journal, LiNQ, Rex and The Sleepers Almanac (forthcoming).

Keywords:

Creative writing - multimodal - short story - typography - illustration 
Before the castle, I designed the Clear Buccaneer - a full-scale, glass-bottomed pirate ship. Guests sat in the hull and stared through the glass at sea monsters and underwater caves.

Since the Buccaneer's opening Tim and I had come down a few times to inspect the queue. We were walking towards the dock one Tuesday afternoon - February 22, actually - when it happened. It was the end of a particularly hot Gold Coast summer and I remember sweating in my shirtsleeves as we waited for the pirate ship to return from its journey around the Historyville River. The ship was pulling in and the girl on the dock was tying the rope to the iron bracket on the hull. The rope was supposed to be made of hemp so it would snap easily if the ship drifted away from the dock, but the hemp rope had recently been replaced with a nylon one to save money.

So after the girl tied the ship to the dock, the nylon rope stretched instead of tearing, and the bracket was pulled off the hull. It hit a young woman in the chest. It was about the size of a laundry basket.

The woman had been standing at the front of the queue with her husband. They were putting on sunscreen and she passed him the bottle before she got hit.

An ambulance was parked on Pioneer Street, about 50 metres away, but the woman was already gone.

A guy in the crowd had twisted his ankle. A paramedic asked if he wanted to go to hospital. He said no. They gave him an icepack.

It was about 4pm. We closed the park early.

We'd had a few accidents before. Years ago, I was mortified when my first rollercoaster malfunctioned, leaving a woman and her two daughters stuck at the top of a loop for nearly three hours. They said later they couldn't stop thinking what would happen if their harnesses opened or the brakes switched off and the cart slid back down. I put a cushion against the wall in my living room and stood on my head for as long as I could. I only made it to an hour before it felt like every vessel in my head would burst.

Another guy a few years back climbed over a fence and entered the restricted area under a rollercoaster. He was nearly decapitated when the riders passed over him and a woman's legs smacked into his head. He broke her legs. His friend, who was waiting for him on the other side of the fence, said the guy went in to get his wallet, which had fallen out of his pocket while he was on the ride. Someone in the queue said it looked like the guy was trying to grab the rider's feet. I don't know. We never found the wallet.

So anyway, the Bureau of Fair Ride Inspections sent some people over to check the pirate ship and question the captain. After the police-tape was taken down, the Clear 
Buccaneer stayed closed for a fortnight while park maintenance replaced the rope and the bracket.

At 11 o'clock one night, a few days after the pirate ship was reopened, a fire broke out in Fantasyland Castle.

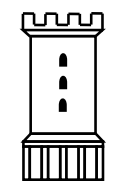

The castle is Fantasyland's centrepiece, perched on a hill in the middle of Fable Forest. You can see it from pretty much anywhere in the park, even though it's scaled down to 30 metres. It used to house a restaurant called The Grimm's Grill, where the wait staff dressed as peasants and served lemonade in clay mugs.

Hawthorne rang me at $2 \mathrm{am}$ and told me about the fire. I think he stayed at the park all night. He's been our director for 15 years and almost every day he goes into the park and chats to customers while he waits in line for the rides.

He called an emergency Dreamscaper meeting. The Dreamscapers being a team of twenty artists, designers and engineers who invent Rohan Brothers Movieland's rides. Our office is backstage, disguised by Cyber City's Ministry of Transport. Costumes are in the basement. Every morning the staff come in from the parking lot and emerge, dressed as elves and cowboys and robots, into the park.

Hawthorne was waiting for us in the meeting room the next morning, drinking a long black while he stared out the window at the smoking wreck of the castle. Like I said, you can see it from anywhere.

He said the fire was all over the news. Attendance figures had already taken a dive after the Buccaneer incident. Management were talking cuts.

He put my division in charge of redesigning the castle. The original had been around since the park opened in 1987. Hawthorne said the new one had to be fresh, exciting.

'We need movement,' he said. 'Sounds and lights. Fireworks.'

His phone rang.

'More importantly,' he said, 'we need the fucking thing back up as quickly as possible. And it needs to be cheap. Dirt cheap.'

He said we should try to recycle the parts of the castle that were still standing. The fire had spread slowly because the castle was made of steel frames and reinforced concrete covered with gypsum plaster. Two towers and part of the wall had survived.

Hawthorne's phone kept ringing.

'Remember,' he said. 'Fast. Cheap. Fireworks.' He ran out of the room.

Everyone started gossiping about the fire. I was worried about what Hawthorne had said about cuts. I knew I wasn't his favourite. I was the oldest member of the team and I'd got the job straight out of uni. Maybe I wasn't exactly cutting-edge. 
Tim came in late. I filled him in. He looked worried. He wasn't in Hawthorne's good books either. He has great ideas, but they're preceded by long stretches of procrastination. He designs his own T-shirts on the Internet and claims to be an expert in ancient metal-making; says he smelted his own sword out of iron ore in a kiln under his house fired by damp sheep manure. I've never seen it.

Still, he's the only Dreamscaper I talk to outside work. I never liked hanging out with large groups of friends. I tend to have one sort of intense friendship at a time. That's partly the reason why my last girlfriend and I broke up - we never had any other friends. Just the dogs. Julie used to train seeing-eye dog puppies. For a year or so we'd teach a Labrador to pick up our car keys and stand on its legs to open the fridge, and then we'd take it back to the seeing-eye dog people and they'd give it to a blind person. Eventually, our relationship ended up in sync with this cycle of puppies, because they calmed Julie down. She never shouted when the puppies were in the room.

I never shouted, full stop. Whenever Julie got upset an almost supernatural calm would descend on me. I never raised my voice, even at the end. I could never confront her directly - instead, I pretended to mishear things, failed to react.

She was my first girlfriend, and when we broke up nearly 10 years later I felt like I was back at square one in a lot of ways. When I looked back on my life it seemed so narrow. I guess it happens to a lot of guys my age when a long relationship ends they look around and realise they've concentrated on work their whole lives and they have no social safety net to fall back on because they always thought of friendships as secondary. I saw it with my dad. He always wanted to buy a little cottage out in the bush when he retired, maybe the Blue Mountains, but he was a cautious man and after he and my mum got divorced he invested in a business. I don't think he had anyone he felt comfortable discussing the idea with properly (although I did warn him it wasn't sustainable). He lost everything. He was trying to play it safe.

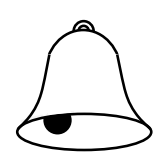

I spent the morning organising my division and messing around with blueprints. As Senior Concept Designer, I'm in charge of developing new ideas. When Management need a new ride, the other designers and I spend a month or two brainstorming and writing proposals.

After lunch I took a walk through Fable Forest. It was Wednesday, so there weren't many people around. Through the trees I could see a construction worker in a cherry picker beside the remains of the castle's clock tower. The fire had destroyed the tower's wall on one side, leaving a spiral staircase exposed like the inside of a seashell. The conical roof had caved in and the clock-face was charred and cracked.

The clock tower used to house a carillon, a set of 47 bells that played a different Rohan Brothers movie theme song every half hour. The songs were played 
automatically, by clockwork: a series of wooden gears turned a giant cylindrical barrel with pegs sticking out of it. The pegs struck wires attached to the bells. The mechanism was a replica of the sixteenth-century carillon in the belfry of Bruges. I guess it sounds kind of lame, but it used to be my favourite thing in the park.

Only the bells survived the fire - the clockwork had all disintegrated - so the man in the cherry picker was lifting them out of the tower.

The other construction workers were erecting a wooden fence shaped like a giant hedge around the moat. I showed them my ID and they gave me a hardhat. I sat on a bench in front of the castle and watched the cleaners skim ash out of the moat with pool scoops. The smoke had stained the Swan Boats grey. Real swans used to swim in the moat but they muddied the water, so park maintenance planted junipers along the bank. Swans hate junipers.

The left side of the castle was completely gutted. The two remaining towers on the right side were tall and cylindrical. One of them had a circle of columns around the first floor. A spiral staircase wound around the other.

Because of the moat, the new castle would have to be the same size as the old one. The simplest solution would be to build out from the surviving section - maybe add two identical towers on the other side. But an ideal castle would be asymmetrical, so it would look different from every angle.

I didn't want to go back to the office. I don't always work well in groups. Even up to my late teens I was afraid of talking to the cashiers at supermarkets, and I got pretty thin because I kept putting off buying food. I remember how people I used to see all the time would tell Julie stories, after only meeting her a few times, that they'd never told me. So I would learn about them indirectly, through her.

I found myself imagining the husband of the woman who'd been hit by the bracketlet's call him Dave - sneaking over the perimeter with a jerry can. I imagined him crouching at the base of a tower with a match and then running back over the drawbridge - if only we'd made it retractable! - and standing in the forest, watching the slow, heavy sweeps of flame as our castle fell.

I felt sick. I knew it was irrational to think Dave had set the castle on fire. The police never found any traces of accelerants. But I couldn't help thinking he'd taken revenge for what had happened to his wife.

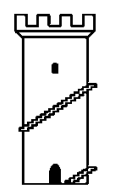

I worked late and when I got home I took out my M\&Ms tube.

I started losing my sex drive about two years ago. I stopped feeling things so strongly. I was circumcised at birth - even though I can't remember my family ever going to church - and my penis often feels dried out. The head rubs and burns against my pants. I guess it got desensitised. 
About six months ago I read on the Internet about all these other guys who were experiencing the same problem. I was sceptical of course. There was some pretty weird stuff out there. But I found this site about uncircumcision. Foreskin restoration. You can get your foreskin back with surgery, or you can do it yourself, by stretching it. Apparently some Jewish men even had underground operations on their foreskins to avoid detection in Nazi Germany.

There are a dozen or so devices on the Internet, but I didn't want to buy one because I felt weird about it, and anyway I figured it probably wouldn't work. So I made my own, just to see what would happen. When I was a kid I had buckteeth and I used to press them against the bedhead every night so I wouldn't have to get braces. It's kind of like that. I use one of those coloured tubes M\&Ms come in. I used to keep a couple of them in the bottom drawer of my desk for when I got hungry at work. The tube's ten centimetres long and has a diameter of about three centimetres. I place the end over my glans and then fold my foreskin over the end of the tube. Then I hold the skin in place with medical tape, which I bought at the chemist. Then I pull on the other end of the tube to create the right amount of tension. I do this for three or four minutes, and then I give myself a break for a minute or two. I repeat this procedure five times. There are lots of other things you can use instead, such as film canisters, eggcups, candle snuffers or trumpet mouthpieces. It took me a while to get it right. It's uncomfortable, but it's not supposed to be painful. I was impatient in the beginning and I kept stretching the skin too far, until it was red and tender. But I've already seen a growth of about a centimetre, so I should be done in another six months. Some people say it's just a placebo effect, but it's really making a difference. It feels so much more protected. There's no more dryness or itching. Some days I wrap an elastic band around the end of the foreskin, to hold it in place over the glans. The skin's not long enough to stay there by itself yet.

When I finally got to sleep that night I had this dream where the old castle was sitting intact on its hill, and then this other, sort of blurry castle, which I instantly knew was the castle that I myself was going to create in the near future, sort of descended, upside-down, onto the first one, and the crenulations on their towers and walls fit together as neatly as zippers, and I grabbed the second castle and tried to pull it off the first one so I could examine it and see what it looked like, exactly, but the two castles were stuck tight, and no matter how hard I pulled on the things I couldn't get them to unzip.

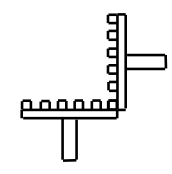

The carousel in front of the castle has 36 horses with bells attached to their bridles. Originally each horse's bridle was unique, but kids kept fighting over the one with the bells. Now they all have bells.

It was a month or so after the fire and I was sitting in front of the carousel desperately trying to think of something because Hawthorne had given my division two days to submit a preliminary design. Tim was frantically throwing together something about 
building the new parts of the castle completely out of stained glass. The others had a few sketchy ideas but nothing we could really work with.

I was worried about Hawthorne. The park was in a bad place. Tim said the recession was keeping attendance figures down, like when all the old amusement parks in the US went bust after the depression. The Department of Health and Safety were fining us for safety violations at the dock, and Dave was suing the park for negligence. Three million. As the chief engineer of the pirate ship, I'd have to give evidence. Just thinking about it filled me with terror.

I'd slept under my desk a few times, not because I really needed to - it just seemed like such a rigmarole to have to leave and get in the car and come back again in the morning. I didn't really mind. I just wasn't getting anywhere.

And then, all at once, as I sat on the bench in front of the carousel, I found myself thinking that if the carousel were cut in half and the horses were removed, and the top half were positioned perpendicular to the bottom, their poles could interlock like the teeth of gears.

And then I had the idea.

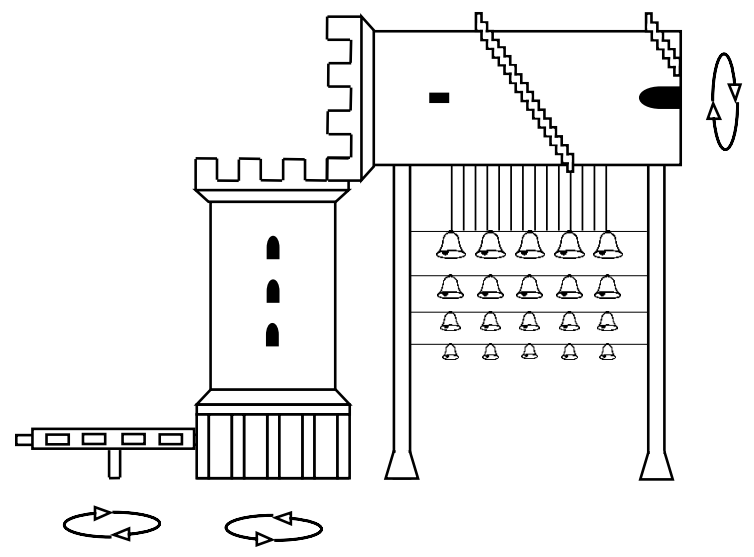

I suggested we turn the castle itself into a carillon. It's pretty simple. The first tower is on a revolving platform. A large gear spins it by interlocking with its columns. The crenulations on top of the tower spin the other tower, which is suspended horizontally, supported by two iron frames. The horizontal tower plays the role of the barrel in the original carillon - as it rotates, its stairs strike a series of levers, which ring the bells.

Hawthorne thought it was a great idea and after we'd drawn up some blueprints the builders started adjusting the turrets and reinforcing the towers' walls. The only significant change they asked me to include was a flight of stairs leading to a platform inside the horizontal tower, where they installed a small restaurant, so guests could eat while they watched the tower spinning around them.

Within six months the castle was reopened as Clockwork Keep and our attendance figures have slowly risen ever since.

They tuned the castle to play a song from The Piano Tuner, my favourite Rohan Brothers film. It's about a man who's born with six fingers on each hand. He becomes 
a social outcast because he's so self-conscious about his fingers, and spends all his time in an abandoned theatre listening to classical records. He really loves music, but he's never been able to play an instrument because his extra fingers get in the way. So he fills the old theatre with trumpets and flutes and clarinets and organs and bagpipes and violins and any other instrument you can think of. Then he takes them all apart and uses the pieces to make his own instrument - this crazy combination of tubing and harp strings and piano keys. It takes him a long time, because he has to try out a lot of prototypes, but eventually he creates this strangely beautiful machine that fits his fingers perfectly. He plays the song at the end of the movie to a sold-out crowd. 


\section{Research statement}

\section{Research background}

Graphic elements are increasingly common in literary fiction, aided by developments in digital technology and the popularity of eBooks. Gutjahr (2001), McGann (1993) and Schiff (1998) show how images and typographic elements can contribute significantly to character development, setting, pacing, tone, theme and other key elements.

\section{Research contribution}

The Carillon explores new meaning potentials for the visual mode in literary fiction by combining two visual conventions: images serve as both illustrations and section markers. Symbols introduces each new scene, fulfilling a function traditionally performed by a title, heading or line break. By subverting convention, illustrations reflect the sense of momentum in the written text, while engendering a stronger sense of narrative cohesion.

\section{Research significance}

This work experiments with placement and sequence as a subversion of traditional ordering of illustrations, which conventionally appear beside or after the written description of the object they represent. Showing illustrations first produces a 'dual time scheme' and a sense of 'implication' of what will happen later (Sillars 1999). As such, The Carillon develops new ways to consider the form and function of illustration within a conventional short story.

\section{Works cited}

Gutjahr, PC 2001 'The letter(s) of the law: four centuries of typography in the King James Bible', in PC Gutjahr and ML Benton (eds) Illuminating letters: typography and literary interpretation, Amherst: U of Massachusetts P, 17-44

McGann, J 1993 Black riders: the visible language of modernism, Princeton: Princeton UP

Schiff, KL 1998 'The look of the book: visual elements in the experience of reading from Tristram Shandy to contemporary artists' books', PhD thesis, U of Pennsylvania

Sillars, S 1999 'The illustrated short story: towards a typology', in P Winther et al. (eds) The art of brevity: excursions in short fiction theory and analysis, Columbia: $\mathrm{U}$ of South Carolina P, 70-80 


\section{Flinders University}

\section{Gay Lynch}

\section{The speculative fiction umbrella}

\section{Brief biography:}

Gay Lynch is an honorary research fellow in creative writing and English at Flinders University. Her interests lie with Australian settler history, contemporary literature, and creative writing pedagogy. She has published papers on these subjects, as well as Apocryphal and Literary Influences on Galway Diasporic History (2010), an adult novel Cleanskin (2006), short stories in contemporary anthologies and educational children's texts. She was Fiction and Life Writing editor at Transnational Literature from 2011 to 2015. She is presently taking a break from teaching to complete a resubmit of her historical novel to a major publisher. 'A good man is hard to find' can be found in Sleepers Almanac $(10,2015)$ and 'The abduction of Ganymede' in The Best Australian Stories 2015.

\section{Keywords:}

Creative writing - genre - popular fantasy - speculative fiction - economic rationalist higher education 
The sky morphed from generic blue to bruisy black as Angel, ochre-faced, a cloak of charcoal-smudged hair rippling behind her, fled her father's death head along a corrugated track that led to Bespoke University. Tumbling, screaming, crying collapsing twice at least - upon the grassy verges, weighed down by adverbs, adjectives and the definite article, seduced by clichés and rhetorical questions, exhausted by repetitions, Angel's boody felt faint from continuous exertion.

For three days she ran, on and on, stabbing Spec's beak into the limestone path ahead. This he allowed - this small autonomy. Dark, svelte, masterful Spec. Nothing could be more explicitly speculative than a black umbrella. Angel fingered his beady weather eye as she strode along. Over and over, a disconcerting image swamped her thoughts, of her white-faced father, gurgling, drowning in his own blood; an image that featured Spec hovering over him, clawing at his throat.

What drove her through forest after generic forest, in which giant trees cast Weyrd shadows? What compelled her periodically to rest her hand against her hard belly? Education drew her - led her. Trick or trope? She closed her fingers around Spec's slender, blue-feathered neck - he was more reliable than any brother but so literal. Why after she'd taken his smooth, sweet head into her mouth, he made her father a McGuffin but - brolly, oh, brolly, oh love, the blood.

On she sprinted until the metronomic creak of a wooden frame strung between two live ghost-gums pulled her up short. Back and forth it swung, setting off yellow-eyed fruit bats. A pox, a hex, a Hendra virus, a Chlamydia, on medieval settings.

Down swept Spec with a flick of Angel's blanched and blue-veined wrist. Such a whack belied her small revulsion, forcing the crude and cruel construction to rotate, revealing a generic male body espaliered like a pear. The body, the specter resembled her father but could surely, nowt be him, in seeming agony, morphed between this life and the next. At Angel's direction, Spec deftly twisted his kingfisher beak to gouge out the chap's eyeball, stabbing at the once-man's spongy private parts no longer protected by his dillybag. Angel hid the bloodshot, gazing eyeball on her person.

'More gore.' A European bird - the lesser raven - erupted from a river gum.

It was symbolic: black and moody, awesome, avian, loud.

It swooped again as she grasped the man body's bag abandoned at the base. Inside, she found a painted stone miniature of two freckled, ginger boys joined at the hip, five bark business cards spattered with blood, and a letter from a student to Lien Jambon, creative writing teacher. Father. Had he flung his seed thus far or kurrsed fellow writers' curs to make them double? Carefully, she unfolded the letter.

Dear Lien, Dr Jamb, Professor Jamblien,

I endured testing trials last week. Collapsing, heating up, flying a bit into meltdown. At four am I wanted to push on fir you because you have invested in my potential wellbeen. I missed the bus in the morning by centimetres and went nearly spare. My heart was beating my bones like an orgasm.

Could you let me know if the workshop was important: write down the things I 
missed?

For all the dust and drang, a new idea galloped into my intelligence. It came from another world. A bit like dreaming or history but not really.

I know this assignment requires a story informed by my research on a contemporary issue but I've been under a lot of pressure lately and I want to right won about fairies. There'll be an issue. I promise you. And a realistic mediveil setting. After the sword fight I'll be speculating about strong girls.

Sincerely,

Fantsay

Angel tugged at her blood-red feather frock, loosening the strings to make more room for her father's steamy eye, between her burgeoning cherry-ballert breasts and for the cards, the stone miniatures and the letter. She supposed she would need a body of evidence or was it evidence of a body to get into university and a disembodied Jambon would do. With Spec's assistance she poked the rancid corpse, sans eye, into her own ham bag, carried not to accessorise but for opportunistic gathering. She imagined Big Jambon's response to the Fantsay chick were he alive.

'What's different about your village, Fantsay?' he'd probably ask in all sincerity.

Humping the festery ham bag, Angel lurched through several imaginary draft paragraphs, partly seduced by stones arranged in glowing ellipses along the creek beside the path, until she finally arrived on the perimeter of a mansion of Gothic pretensions, its four towers wavering, all of a whimper on her approach. The cloud dispersed, the sky bled red. Nothing augured well. But why should she defer her studies because misfortune had overtaken her family, especially her dad, her own Jambon on the bulldust-strewn road to higher learning?

She had not anticipated meeting the subjects of the miniatures. Nor expected to submit a portfolio of mutilated body parts for her creative arts enrolment. The unfortunate gingery twins stood chanting at the gate, their rubbery torsos gyrating in a semblance of harmony. Between one cant and the next, they spat obscenities and something creamy and globulous they'd cleared from the back of their throats, its smell resembling bridal creeper. Angel replaced the kerchief at her nose with another. The dribbling heads lolled towards her until she dropped her ham bag at their feet. One pair of hands thrust themselves between her breasts; surely not intuiting the presence of their father's eyeball.

Angel dropped her head like a grinding stone upon wattle seed, bit down hard on the bird-thin fingers. Then leaned in, allowing her teeth to graze at a singular throat and whispered. 'I know Jambon.'

The hands clasped each other, the heads swivelled to take her in. 'You'll get nothing from our father. Do you have other friends of consequence?'

'I have five hundred friendly faces upon my bark pages?' 
'What have you read then, love?' the second face thus spake.

'I've read Harrold Potter's dreaming seven times. I have every known narrative strategy at my disposal.'

The twins conferred. 'Years ago, they regurgitated Shakespeare or kinship networks at the cattle grid; likely, settings make them suggestible.'

'You mean, relatable', Angel responded. 'I have my rights and I'll fight for every one of them. Take me to the governing body.'

'At Bespoke University our vice chancellor is available in drought years and during partial solar eclipses. First, you'll have to accredit yourself with us. Can you punctuate? Can you attribute discourse gleefully, bashfully, beatifically.'

'Fuck the lot of you. I have Lien Jambon's body in a bag and I want to write his eulogy under supervision. Tell me the pre-reqs?'

'Weeping St Agatha.' They ducked their heads and conferred. 'She's done away with our dad?'

The first head squealed. 'Wave her through while we review her application. She has a pulse. A plan. Possibly a tax file number. She's registering on my heat-seeker.'

The second head recoiled. 'She stinks and she says she's related.'

'Then she's a grim skiter,' the first head complained, carrying his breastfed finger to his nose.

The other viewed his travel-worn image in miniature, and began to weep and roll his purple doublet into a sausage shape. 'You honour his journey?'

'No more journeys,' Angel cried. 'I never want to hear that word again.' Stepping forward she kissed him hard upon the mouth. Then lay her lips, upon their ears, four eyebrows, two salty tongues - their pair of crenellated navels. Their skin allured, smelling sweetly of roasted feral-pig, of home brew and wild thyme but they acted so young, with such passivity, were possibly her siblings.

One wafted his hand towards the cloisters. 'Take the bag and run, girlie.'

'Ascend,' the other said. 'Enter at any level, traverse the battlements in all four directions, take coupons from each and swipe your card; compose thirty-six thousand words.'

She drew away, leaving them seemingly ponderous over the miniatures of their strange selves, and ran to the far side of the gibber keep. There she approached a green painted door and struck it with Spec's beak.

A grinning creature wearing a bottlebrush wig popped out, its generous and elevated décolletage as fringed, as generic green, as any rainforest pool. Mammaries, rather than binaries, it seemed, were the campus convention.

'There's not much going on at the moment in Womanish Study,' she said. 'We've shoved everyone off to herbal therapy and crone-care. I sign off on the sheets. What's your paddock?' 
Angel was done with care. Now that she'd dispatched her father to the next world, and she felt half-hearted about claiming a couple of birth defects as brothers. She hummed as she always had, when lacking commitment.

Spec growled and rustled the silk between his spokes, worming his way into her smalls; she sighed in a liquid way, before she smacked him down.

The red-crested female persisted, quill poised, scratching observations on dirty bark sheets. 'Council modelling suggests genre's big: collect tokens for a year in Fairy Tales, a year of plot summaries to fire up the canon; a year of philosophy and you're done. Then you can write your disquisition on Daddy.'

Angel continued to hum.

'May as well let you know. No stock characters. Make something up. Vice-Chancellor doesn't like allegories. Two bucks says he's sick of fairies. Even gumnit babies.'

'That's new: the no pointy-ears rule. Thanks for the tits.' Angel inclined her head in deferential manner. Bloody anachronism. What would she know? Father's Fantsay couldn't get enough of it.

'Sexual tension's huge,' the red woman added. 'And genre-bondage.'

'I could write Romance then.'

'Only with blood and a lot of neck work.'

She may just as well stick with the father project. Angel handed over two of the bloodspattered stones.

On she quested. A sign above the next knothole spelled philosotree in torch-charred letters. At the keyhole Angel drew herself up full of entitlement, flashing the ham bag containing its remaining accreditations: bone and gristle, and a few shrivelled abdominal organs; then whipped from her bodice her father's bleeding eye The trunk groaned creating an orifice. 'Putrid.' It slammed shut in a trice.

'Oy,' Angel bluffed, holding up Jambon's eye 'like' she might a charm. Well, 'as if' she might a charm.

Once more, the tree aperture expanded, its keeper allowing her entry. Several water snakes recumbent on velvet sofas waved her in with their tails. The largest, a fleshylooking melancholic, barely glanced up before returning to studying his tablet; three played games with tokens, slapping them onto a low stone stool sculpted in the shape of an egg; a fourth, rolled his puce-coloured jowls at her, as he recited the periodic table.

She tried to gain their attention. 'Hello. Hello, Red-Bellied Things. What's the game? How do I win?'

'What kind of question is that for a philosopher?' one replied.

'Commerce, third tower on the left. On your brumby', the portly one grumbled.

'Aren't you all philosophers. Don't you get metaphor? '

'Fuck you. We know more about Aristotle and Poetics 22 than you or anyone. About 
setting up a wretched couch and a puny table. You exist for You. Ignore second person. Faddy. What are you here for? Do you have stone tokens? Do you see a point apart from your umbrella's? Do you exist?'

'I gave the crone my tokes? Do I have to submit to someone else to apocrophise my father's life?'

Spec shivered with delight at the mere thought, brushing past her thigh as he rose.

At that very moment, the ginger twins burst into the room. 'Ask her about our father, reptiles,' the left head bleated. 'We think she knows a fair bit.'

Spec leapt towards them like a startled roo, and took off the first brother's carroty head. He thrashed it against the stone table until it turned into a ball of putty, which he rolled beneath the table; there it lay, leaking ghastly fluids, its mouth pulled back in a final grimace. Like father like son. Spec knocked out the second twin's teeth with his beak. The snakes reared up on their silken sofas and slid away through a portal onto the patio. Angel pursed her lips. Spec always went too far. First killing her father; now her perhaps brothers. She drew out Jambon's eye once more and attempted to pass it off as a curse. Its condition had further deteriorated. Spec ignored the rancid thing and parried. The second head fell heavily, blood running out of its ear.

'Spec, no. A brother is not as easily forgotten as an umbrella. A bloke named Jim once said that.' She eased Spec between her thighs and moaned speculatively. Then she angled her brolly through the turret window, to the prevailing wind, crying out, 'I must go home. It's a question of belonging.'

Back along the bromide-tangled track she trod, refusing to journey, through the Weyrd shadowy bush, beneath bruisy clouds, past Jambon's empty, swinging frame where she replaced the dilapidated eyeball. Endings never entirely satisfy but Angel found redemption in decapitating her umbrella, hurling its dagger-bill, followed by its body into the creek. Seven shining girls emerged from the water to grasp his hilt but Spec's point turned back on them, sliding between their ribs. They promptly dragged his other bits below the surface. Within seconds bubbles rose.

Thighs spread Angel hunkered down on the riverbank. She would write her father's stories solo, while speculating about her best protector - such a trickster. Every story owned one. Three pushes. Three spiky bloody little creatures emerged now in the thin sunlight between her legs and crawled upon her belly. Eat light, little brollies, before you fly into the azure sky.

\section{Dear Fantsay,}

Forget fairies. Siblicide's a cause, an isshew, worth taking up.

Cheers

Angel. 


\section{Research statement}

\section{Research background}

'The speculative fiction umbrella' continues research about how university creative writers might reprise popular fantasy tropes as new knowledge, and whether the 'speculative' genre term is oxymoronic in relation to some popular fantasy texts. This story uses the quest trope and postmodern techniques - blended genres, pastiche, playful intertextuality, borrowed motifs, metafiction, irony and satire - to critique these texts, especially their stylistic excesses in both the market and some student submissions. Its protagonist embodies the daffy sexuality, schlock horror agency and determined pragmatism present in some texts. Hutcheon argues that 'parody works to foreground the politics of representation' (1989: 93).

\section{Research contribution}

The story argues, in hyperbolic fashion and in the face of well-attested student homage to popular fantasy tropes, that university creative writers should privilege new knowledge (to know, in response to understanding texts) and innovation (creating anew). Set in a higher education world that is realistic and absurd, it deconstructs itself. It applies farce, parody, double entendre, irony, malapropism, slapstick, sexual innuendo and non-sequitur to create an unrestrained Rabelaisian effect that could encourage reflexivity and critique and prove generative.

\section{Research significance}

According to Palmieri, 'satiric narrative works indirectly through parodic alteration of celebratory forms, established discourses, and dogmatic pronouncements' (1990: 1). This story is dialectical and has been accepted for publication in TEXT, to contribute to debate about the use of popular genres including fantasy in creative writing pedagogy.

\section{Works cited}

Hutcheon, L 1989 The Politics of postmodernism, London and New York: Routledge

Palmieri, F 1990 Satire in narrative, Austin: University of Texas Press 


\section{Southern Cross University}

Nollie Nahrung

Little snatches: becoming-girl, becoming-woman through the touching glass

Biographical note:

Nollie Nahrung lives in the Northern Rivers of New South Wales. She is a university medallist and $\mathrm{PhD}$ student in the School of Arts and Social Sciences at Southern Cross University. Her PhD thesis, 'Relational anarchy with art: textual escapades in theory, practice, form and content', is an interdisciplinary work that traverses cultural studies, creative writing and digital visual arts practice. Her publications are available from https://scu-au.academia.edu/NolJoy.

Keywords:

Creative writing - collage - tactile poetics 


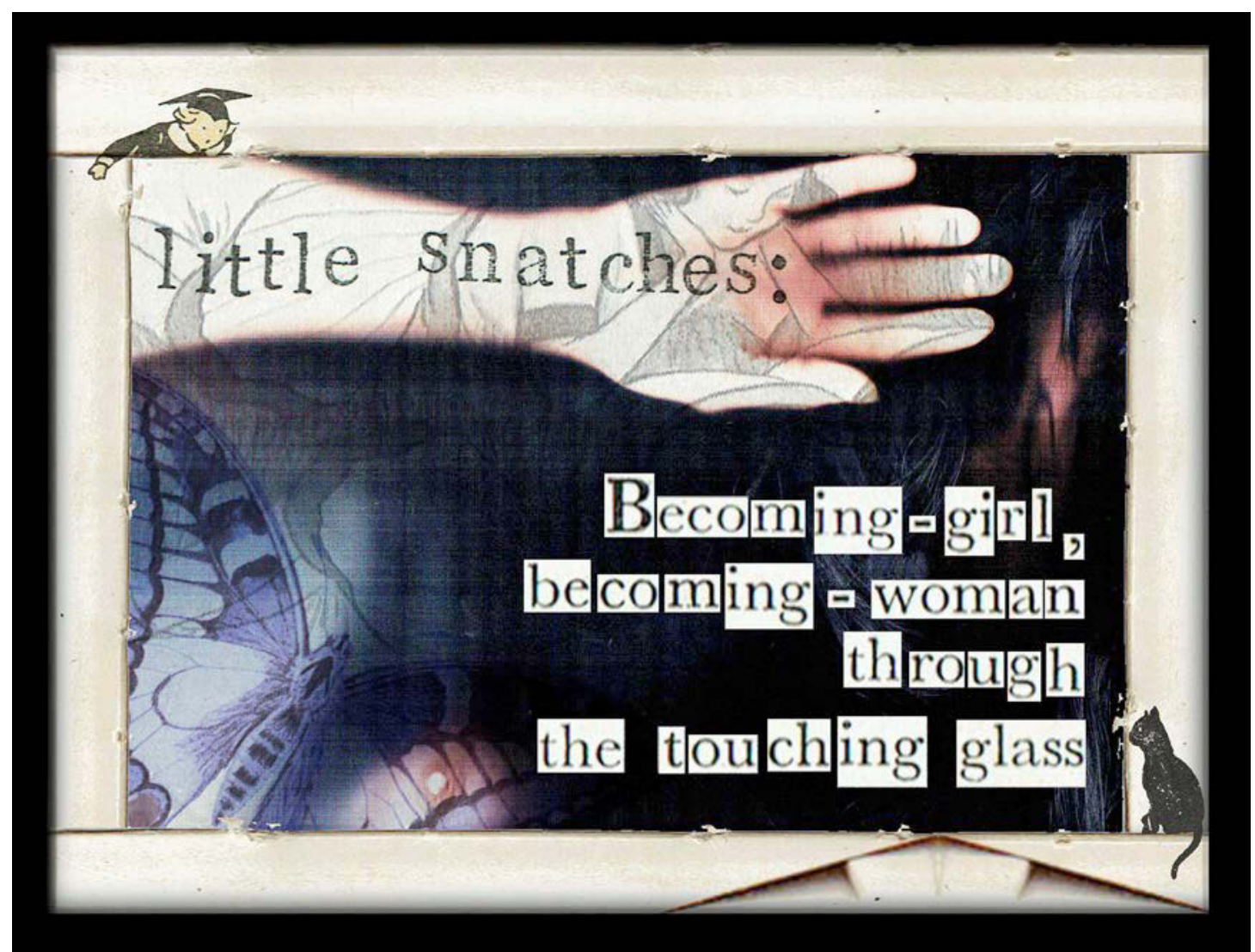

\section{ABSTRACTION :}

what follows (from the middle) is an experiment with theory, practice, form and content, choosing assemblage as its structuring anti/logic (the parts form the whole but you can see the stitches).

rather than "just" talking (does she mean writing?) about deleuze and guattari's concepts, this ... work (? -> yes, a labour!) digitally engages with becoming-girl, becoming-woman / plugging the body into the machine $\backslash$.

copying alice, there is a botched attempt to join her through the looking glass $<$ section has been deleted: EPIC FAIL >.

here (where?), we (is that you? who are you?) rest our tender texts upon the scanner glass, feeling the smooth cold press

$\mid$ how touching $\mid$.

distracted by visions of non/representational images dancing in our heads/bodies, the light passes below : becoming digital; where might we end up? wonderlanding, we find ourselves in photoshop (a proprietary technology of adobe systems ltd). we hold hands: little snatches at the plane of eomposition immanenee. $\{$ ? $\}$

we because your reading forms part of this assemblage in the theory-practice-content-form of the question-answer: does it work? rather than is it true? (italicised words=Massumi 1987 MISSINGPAGE NUMBER ALERT!!!!) (Massumi 1987: xv) (xo, Brian). 


\section{dear reader,}

are you looking down on high from above (do i look up to you? is your head in the clouds?). might instead you choose to live molecularly with the text ... use their [your] imagination to exit the mapping with the opening of a problematic rather than a closing of a solution - or what Derrida terms a strategic indeterminacy?' (Alecia Youngblood Jackson, page five hundred and eighty four from the list of works cited at the end under the heading 'Works cited'. the relevant citation in this instance commences with the word Jackson and not https://www.youtube.com/watch?v=4GvD NQrLFo, nor a photo of Janet, who is a different Jackson, again) (Jackson 2010:584).

"Do not use direct quotations in an abstract: paraphrase using your own words."

$$
\text { BLESS ME FATHER, FOR I HAVE SINNED. }
$$

but i re:cant - this is not an abstract, it's a ... preamble. but no, it is not precisely that either (is precision a virtue? is it a necessity? why did she bring it up?), for we are already in amongst it all, set in motion (do you agree? is this an ambulation? should we call an ambulance?): to understand, to be intelligent is not our overriding passion (bits from Lyotard there) (Lyotard 2004: 50). he was talking about Nietzsche, but whenever there is Word of a dance (the progressive square kind?) I like to think of Emma and what she supposedly said (Google 'Goldman dance') \{Google is not a verb\}. it is probably wrong to mix things up like that: a mash-up of ideas, or sticking women in where they don't belong /indecorously interrupting the philosophical sausage fest with spurious confabulations (silly girl / smart cunt). but Emma read $\mathrm{Fr}^{(i)}$ ed's books, they kept her up all night; she wrote about what he wrote. so perhaps, perhaps, perhaps ... this is about relationships, not precision (perhaps? don't you know? this is your paper: take a stand! oh damn your eyes, its an e x p e r i m e n t she said: don't the jiving silent graphic servants :-) \{Derrida there, again\} help show that?

(Derrida 1997).

reading/writing/thinking/making/playing around (ooh!) with the work of others ...

Raymond Federman (1976) says "playgiarism", Kenneth Goldsmith (2011) calls it "uncreative writing".

\section{i say Yes, my darlings! Yes! Yes! Yes!}

... and, E', ampersands

... cut and paste, cut \& paste, cut AND paste ...

\{perhaps hearing a small refrain, "she" wanders off-for joining in\}. 

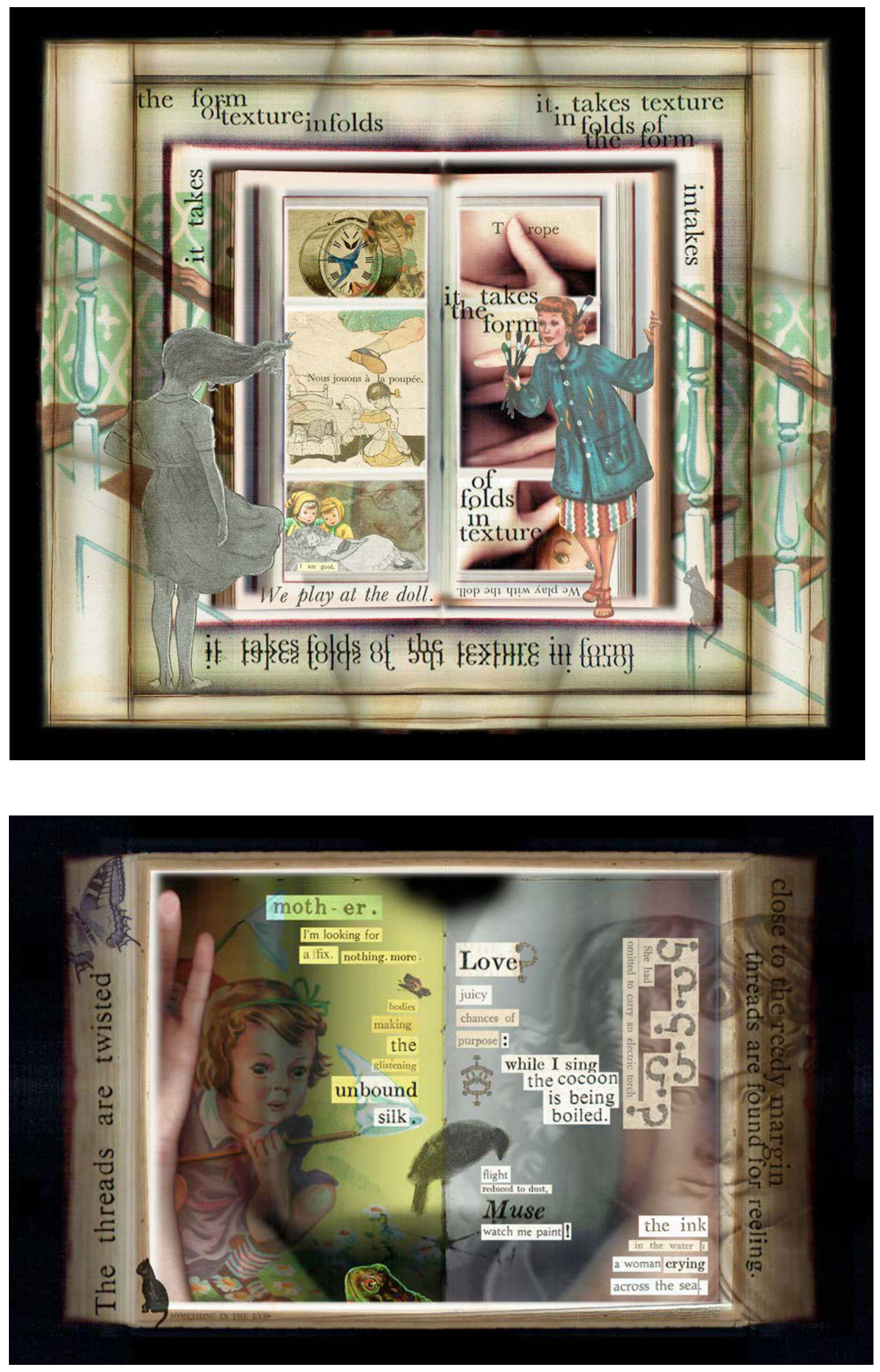


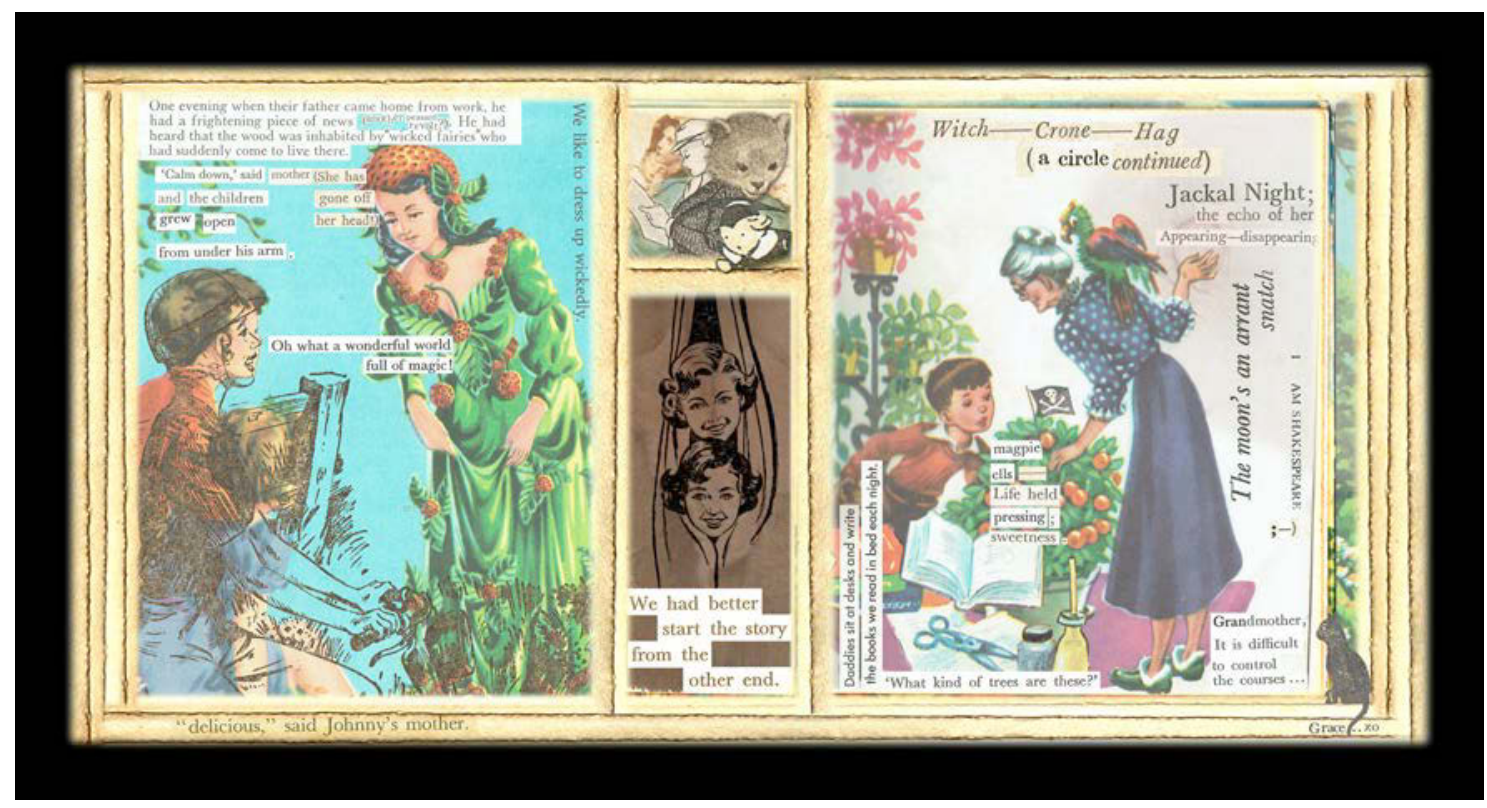

\section{Research statement}

\section{Research background}

Following Braidotti (2003), my research intersects Irigaray's feminism of sexual difference with Deleuze and Guattari's philosophical nomadism. Through visual and written modes of intertextual 'playgiarism' (Federman 1976), my research enacts collage as a model for a 'borderlands epistemology' (Harding 1996), asking how this non-dominant way of knowing could be related to becoming's disruptive deterritorialisation of molar identities and structures (Lorraine 1999).

\section{Research contribution}

Informed by existing feminist scholarship, this work innovatively offers new visual and poetic modes of knowing about becoming-girl, becoming-woman; entwining theoretical perspectives with creative practice. The use of scannography, and remediated text and images from children's books, enacts a tactile poetics (Jackson 2012) that rejects the separation of self and society, symbolic and material, in both form and content. This generates new knowledge about feminine subjectivity from an embodied research position.

\section{Research significance}

From a situated and partial feminist perspective, my research materially illustrates how multiple discourses (e.g. philosophical and poetic) may be intersected and represented through collage. This work has been accepted for publication in a leading peer reviewed journal of creative writing research. 


\section{Works cited}

Braidotti, R 2003 'Becoming woman: or sexual difference revisited', Theory, Culture and Society, 20.3, 43-64

Federman, R 1976, 'Imagination as plagiarism [an unfinished paper]', New Literary History, 7.3, 56378

Harding, S 1996 'Science is “good to think with”: thinking science, thinking society', Social Text, $46 / 47,15-26$

Jackson, S 2012 'So close: writing that touches', New Writing, 9.3, 408-18

Lorraine, T 1999, Irigaray and Deleuze: experiments in visceral philosophy, Ithaca: Cornell UP 


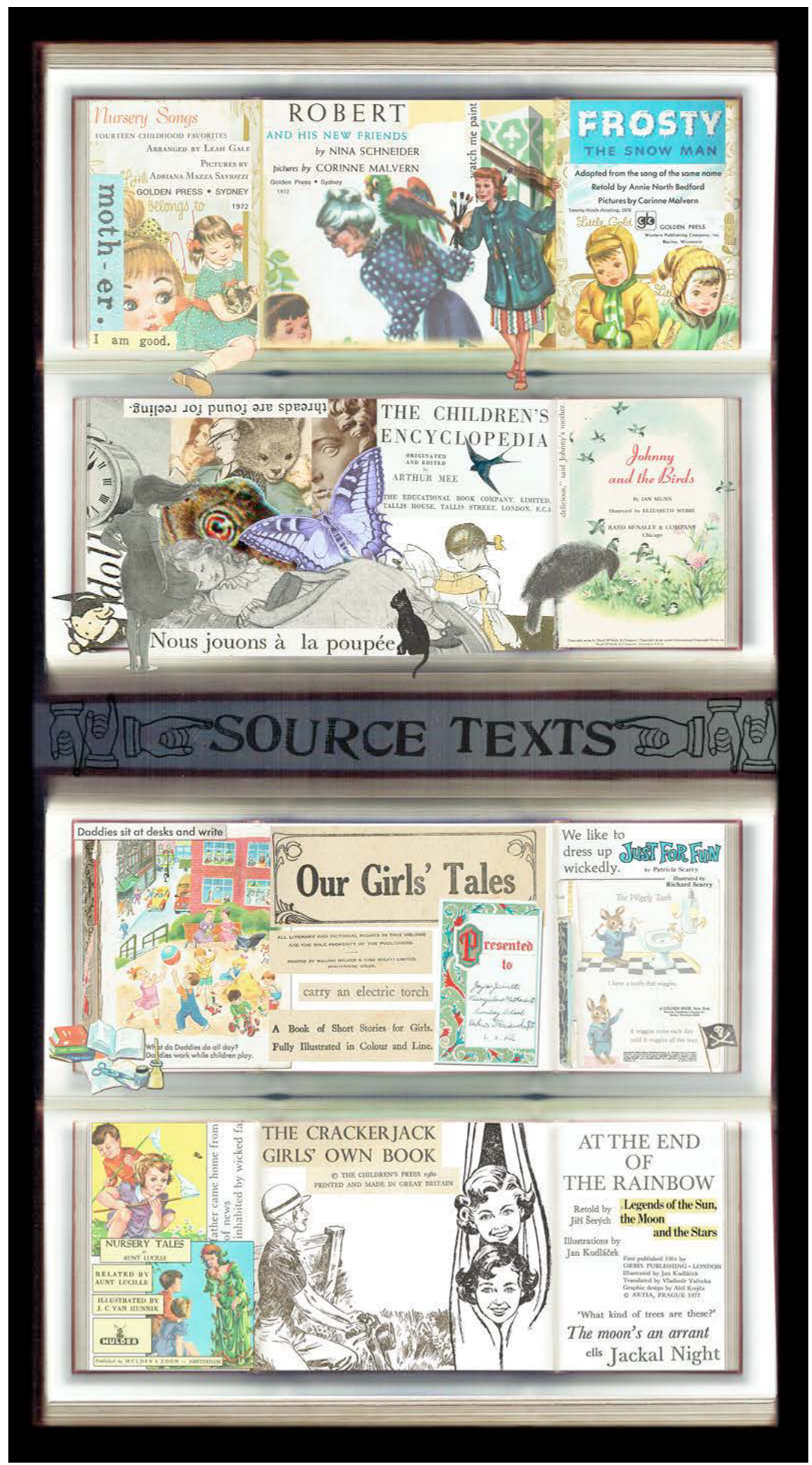

TEXT Special Issue 30: Creative Writing as Research IV

eds Nigel Krauth, Donna Lee Brien, Dallas Baker, Moya Costello and Ross Watkins, October 2015 


\section{University of Notre Dame}

\section{Camilla Nelson}

\section{What you don't know [extract]}

\section{Brief biography}

Camilla Nelson lectures in Writing at The University of Notre Dame, Australia, and researches in the fields of creativity and creative practices, fiction and non-fiction writing, adaptation and history in popular culture. In addition to a range of scholarly and other essays, she is the author of two novels: Perverse acts, for which she was named as one of the Sydney Morning Herald's Best Young Australian Novelists of the Year, and Crooked, which was shortlisted for the Ned Kelly Awards. Camilla has been a judge of the NSW Premier's Literary Awards, the Kathleen Mitchell Award, and the Sydney Morning Herald's Best Young Australian Novelists of the Year award, and has served on the governing board of the NSW Writers' Centre. Her most recent book is a co-edited collection of essays, On happiness: new ideas for the twenty-first century, forthcoming from UWA Press in 2015.

\section{$\underline{\text { Keywords }}$}

Creative writing - paranoid fiction 
The death of Ned Chorley rated a paragraph on the front inside page of three of the metropolitan dailies, before it was consigned to oblivion with the help of a D-Notice and the unexpected return of the mysterious Mr Tirath Khemlani to Canberra. Farley was in the telex room when the telephone rang. He remembered it clearly because it was a Saturday, and he'd had to ring his wife Verity to collect the boys from school cricket, and the sky had been a clear summer blue.

Farley clearly remembered standing by the edge of his desk, having just finished adjusting the angle of the electric fan, which was burrowing ineffectually away through the stifling heat. It was a cranky day, another stuff-up with security clearances, which wasn't strictly unusual given a government of half-baked pinko socialists in which not even Prime Minister Gough Whitlam had permitted his staff to be security checked. Or perhaps he was cranky because the telex machine had been clattering all afternoon, because our American allies were having yet another one of their panic attacks, having long been persuaded that the country was driving itself to rack and ruin. Or perhaps he was cranky because three junior clerks had been passed over when he was hauled back to act as duty officer because young Oliver Combs had called in with a case of the flu. Either way, he was feeling petty and resentful, and had quite possibly been glaring at his secretary Leona Pemberton over the rim of his brown pottery mug.

'It's for you.' Leona mouthed the words in the theatrical style that she used to convey that the station manager, Bill Prentice, was working himself up into one of his states.

Farley took the call. 'Gerald here.'

'You did the security clearance on Ned Chorley, didn't you?' Prentice barked down the line.

Farley cleared his throat. 'I made some inquiries.'

'Find anything?'

'There was nothing to find.'

'It was a prima facie case for investigation.'

'I'm not sure that an undergraduate misadventure constitute a prima facie case of anything.'

'Insolence, Gerald. It was an early indication of his socialist leanings. Was it hostile? The interview, I mean.'

'No, he seemed an amiable chap. Shy, I think.'

'Is that all?'

'I checked the files for records of any kind of communist affiliation. There wasn't anything.'

'Are you sure?'

He'd never heard Prentice so worked up over nothing. 'Absolutely.'

'What was he like?' 
'He appeared to be an intelligent boy, but nervy. I supposed that was only natural, given the circumstances. Why? Has something happened?

'He's dead.'

Farley took his time digesting the news. 'How?'

'Gunshot. At his home. I want you at the scene.'

'You want me to go there?'

'Well, somebody's got to.'

'What about Special Branch?'

'I've already spoken to them. They're expecting you.'

Farley put down the telephone, and stared at Leona's pinched face.

'What's the problem?' she asked.

'Truthfully?' He gave her a smile that was utterly devoid of good humour. 'I'm not sure.'

The $\mathrm{ABC}$ was making its final broadcast before the station shut down for the night. Farley tuned in as he drove through the night-blackened streets. Streetlights shone down through ghostly gums, onto wide-open spaces of bitumen. Eerily enough, the $\mathrm{ABC}$ news was also the first thing Farley heard when he walked into Chorley's suburban bungalow, encountering three uniformed constables standing guard by the door, ashing cigarettes on the orange cord carpet.

Angus McDonald, Superintendent of Special Branch, was standing in the open area under an aluminium-framed picture window that occupied the length of one wall.

'Finally,' he said.

'Superintendent?'

Chorley's study gave off from the rear of the room. From where Farley was standing, he could see an upturned office chair, with a pair of shiny black brogues jutting out at an unusual angle.

'Nasty,' he said, by way of conversation. 'Can I take a look?'

McDonald grunted, and gave him a nod. Perhaps grunts and nods were the only answers Farley was going to get.

He walked into Chorley's office, and looked around.

Chorley was young - for death, at least. He looked quite unlike the gangly young man who had walked around the National Gallery with him, talking excitedly about his future. He had a regulation bullet wound to the temple, with a revolver lying on the floor underneath, all neat and tidy. 'Suicide?'

'What do you think?'

'Looks like. But I'm hardly an expert,' said Farley. 
McDonald almost sneered. 'I didn't expect that you were. Is he one of yours?'

'Afraid not.'

'Was he under investigation?'

'Sorry. Couldn't say.'

McDonald's hackles went up. 'Well, it says so, in the note that he left.'

'Really? Would you mind if I had a look?'

McDonald appeared to think it over for several seconds then ventured back outside. Left alone, Farley spent a couple of minutes poking through the blood-soaked files stamped 'Minister's Eyes Only' that were strewn across the desk. Foreign Assets. Finance Regulation. Nugan Hand Bank.

He also began wondering why Chorley had shot himself in the corner of the room, as against standing by the window, for example, drinking in a final glimpse of the artificial lake that comprised much of the view. It seemed trite, but the bitter reality was that a goodish percentage of suicides actually do not leave notes. Farley wouldn't. He'd probably fake an accident. Swim out to sea. Too worried about leaving Verity and the kids to clean up the mess.

He also caught sight of an indentation on the notepad by the telephone. The top page had been ripped off, but the ghost of the handwriting remained.

'Mr Farley.'

Farley wondered if McDonald intended a reprimand, or if his emphasis on the word mister was merely intended to emphasise his irregular status. He turned round. Saw McDonald standing in the doorway holding Chorley's note in an evidence bag.

Farley read it through twice. It seemed uncharacteristically melodramatic. It protested that he was the victim of paid informers. It typed on a machine with a malfunctioning P.

He handed it back.

'Is that all?' said McDonald.

'No, I'd like to see the other side of his face.'

McDonald looked as if he was going to refuse, but seemed to think better of it. 'You.' He beckoned the three constables who were waiting by the door. 'Turn him over.'

The men bent down and gave Chorley a heave, but the body was more difficult to move than they had anticipated. Rigor had already set in. An arm jutted out. Congealed blood spilled out of the rear exit wound and onto the floor. Farley adeptly ripped the top sheet off the telephone pad as the corpse rolled over.

'Thank you.' Farley gave Chorley a cursory look, and walked out the door. 
The thing that really surprised Farley, turning his petty resentment into something altogether different, was Prentice's appearance in the corridors of the Canberra station at three in the morning.

'Was it awful?' Prentice waved him in. 'Ghastly, I'm sure. Take a seat. Will you have tea?'

Almost on queue, Leona walked in with the tea tray.

Prentice poured.

Farley took the cup of milky water out of his hands and put it down on the edge of the desk, an enviable antique. The rest of the office was curiously furnished with oriental carpets, rattan chairs and a tiger skin rug. The walls were covered in mementos of Prentice's service in several South East Asian hotspots, and behind the desk, a picture of the young Queen. The only things missing were a bullwhip and a couple of horse pistols.

'How's Verity, by the way?'

'Fine,' said Farley. 'Bearing up well.'

'Studying hard?'

Verity was smart, smarter than Farley was. He had always been a little in awe of that. He had supported her decision to go back to university, but was secretly relieved when she decided to take out a master's degree in Old Icelandic and Early Norse. It was utterly non-functional and unlikely to lead to anything much. After two years and four months of Verity's Sunday night reading groups in his living room, he still couldn't remember the names of the skaldic poets (though he remembered the word skaldic, because he had been forced to look it up in the dictionary), he also couldn't remember the names of her tutors, and what was worse, couldn't summon up much of an interest in remembering any of them. He felt guilty about that. What he had inevitably noticed were the subtle alterations in Verity's style, the flow-y sorts of clothes in bright geometric patterns, the pirate-style headscarf, he ought to thank God that she hadn't descended to a velveteen jumpsuit. Prentice was worried that he'd find Verity's face in one of those photographs from Oliver's surveillance unit, protesting against white rule in Rhodesia, burning a flag at a CPA rally. Farley couldn't think of anything further from the truth, but he often wondered how Prentice would react if it was.

Then he felt guilty. Verity made him a kinder, braver person.

'Icelandic Literature,' answered Farley. 'No security threat.'

'Jolly good,' said Prentice, clearly uncomfortable. He broke into another one of his rare smiles and asked Farley about the events of the evening.

Farley shifted in his chair. Briefly, he went through the events of the evening, even going so far as to suggest that the death wasn't as straightforward as it might appear. He also noticed without particular anger that Prentice must have gone rummaging through the locked drawer in his desk, or maybe Leona had given him the key, 
because he had obtained a copy of the background check that Farley had intended to sign off on this morning.

'I think suicide would be better,' said Prentice.

Farley now felt certain that there was something going on. 'They'll say that we pushed him too hard.'

'Did you?'

'Of course not.'

'Then there's nothing to worry about.' Prentice eyed him directly over the tips of his fingers, which were pressed together like a Church's steeple. 'Girlfriend. Failed marriage, something like that.'

'But if it isn't?'

'I don't think that would be a satisfactory outcome.'

'And if things get unpleasant?'

'Then I want you to take any necessary measures to make sure that they don't.'

Farley disliked the way in which Prentice chose to speak in riddles. He liked to make out that everything was more mysterious than it seemed.

'Whitlam won't last forever. At least, not if we can help it. And we can.'

Farley nodded, though he wasn't sure that whatever Prentice was doing was helping very much.

'Honestly, Gerald. I'm a bit worried about this Chorley fellow. It's come at a bad time. I realise you're not a field man. But with Oliver incapacitated you're the best that we've got. And you're always very thorough.'

An unfavourable comparison with Oliver Combs would have upset a lesser person, but Farley hadn't survived five long years under Prentice without a sense of irony. 'I'll give it my best shot.'

'No, Gerald, you'll give it everything.'

Farley picked up Chorley's file and left the room, feeling something rather like satisfaction on finding out that Prentice had proved himself to be every bit as awful as Farley so often imagined him to be.

Farley took the telephone off the hook as soon as he got back to his desk. He considered it unnatural for people to keep themselves in a constant state of communication. He had also been a deskman at ASIO for long enough to know that there were a surprisingly large number of people who were potentially listening in. And Verity didn't seem to mind. He imagined her turning over in their double bed and missing him, then again he had taken to working so many nights of late that he wondered if Verity would even notice he was gone. 
He opened his report on Chorley. There was nothing in it, really. Just an anonymous letter they'd received denouncing him as an agent of influence, together with a dreadful poem from Chorley's university days calling for wholesale political revolution and Bentley's for everybody. Prentice had considered it a significant find, but in Farley's opinion the only terrifying thing was the prose. It was awful.

He kept leafing through the file. There were his university grades, which were surprisingly good for a minor public servant. He had also been a member of the book club, which Prentice had marked down as suspiciously left wing, and the drama society, against which Prentice had made a note asking Farley to check whether Chorley was sexually stable. He obviously had a taste for something more fanciful than was catered for in his university degree, which was in political economy. There were several copies of undergraduate exam papers, entitled mathematical methods of economic analysis, monetary history and theory, all of them remarkably orthodox.

His personnel file from Treasury was equally impeccable. He specialised in money flows, bureaucratic jargon for trade statistics, currency, foreign loans. He remembered Chorley's excited prattle as they walked around the gardens, they had made it all the way to the National Library, a blocky sort of building in which the nation's history was archived. He was childlike in his enthusiasms. He played competitive chess and was building a hobby computer from a science kit in his spare time. Farley soon realised that if he didn't put a stop to it that Chorley would go on like that all afternoon.

It was getting on to twelve when Leona walked in.

'Good grief, woman. Why aren't you at home?'

'I've been home and I'm back for the afternoon. You look like you need a shave.'

'Probably.'

Farley stroked his chin. The envelope was addressed to him. He slit it open and looked over the pictures from the crime scene. Almost immediately, he saw what was wrong. Twelve years in the army had taught him enough about boys and guns to know that this wasn't a suicide he was seeing. 


\section{Research statement}

\section{Research background}

'Paranoid fiction' describes literary and popular fiction that explores the nature of subjective, social and political reality, and its manipulation. In paranoid fiction, reality is always doubled. The world may appear to be definite and real but, upon closer inspection, turns out to be misleading and deceptive. Boltanski (2014) examines detective and spy novels to interrogate this doubled or paranoid reality. He argues that these works, built around conspiracies and inquiries, developed as a way of organizing reality to explain the social and political lives of individuals and groups. This work is an extract from a novel that creatively explores the alleged role of the CIA in the downfall of the Whitlam Government. It gives fictional form to historical and apocryphal narratives about the operation of clandestine groups within ASIO, faked Loans Affair documents, and activities at the US spy base Pine Gap, and investigates tensions between agency, power and social reality in ways that are informed by research into the cultural and political significance of paranoid narratives.

\section{Research contribution}

The extract is taken from the work's beginning, in which the character only dimly suspects that the secret world that he inhabits is not fully transparent. His insights are limited to personal questions and questions of personality, and he is unable to make connections to wider social and political realities, except indirectly through reflections on his wife. Nevertheless, his emotional disaffection is the precondition for eventual questioning concerning the nature of reality and agency, and the exercise of power.

\section{Research significance}

This work extends the author's previous creative explorations of paranoid and dystopic fictions' function as social commentary within the Australian political context.

\section{Works cited}

Boltanski, L 2014 Mysteries and conspiracies: detective stories, spy novels and the making of modern societies Cambridge: Polity 


\section{Waikato Institute of Technology (Wintec), Hamilton, New Zealand}

\section{Gail Pittaway}

\section{Three physical conceits}

\section{Biographical note:}

Gail Pittaway is a Senior Lecturer in the School of Media Arts, at Waikato Institute of Technology (Wintec) in Hamilton, New Zealand, where she has recently developed both an Honours Stream and a Master of Arts in Communication. She has supervised successful research higher degree projects in publishing, creative writing and professional writing. A member of the Australasian Association of Writing Programs executive committee for ten years, her research interests include writing poetry, reading and reviewing contemporary fiction, and writing for radio. Gail is currently a doctoral candidate at Central Queensland University, in the field of memoir writing.

\section{Keywords:}

Creative writing - poetry, biographical - biography - literary conceit 


\section{Charm}

(For Marie Flynn)

Apotropaic magic it's called

when we say 'bless you" after a sneeze

or "cross my fingers and hope to die."

As you lay dying

I became uncharacteristically tidy.

Of course I gardened

but I scooped up weeds immediately.

Books went into a new book case

in height order

and my wardrobe found itself rearranged

according to cut and season,

while all the hangers were made

to primly face the wall.

At the clothesline I recalled your reputation

For organising pegs by colour,

then matching them to the clothes.

I drew the line at that,

but washing has been folded with particular care.

Apotropaic magic.

Auspicious, not superstitious

you'd have found it propitious

that a comet called McNaught visited

our southern skies in that of all weeks.

As you clutch that comet's tail

perhaps you'll look down and see

my rotary clothes line

like a rainbow tree fern?

In case, today, I'll hang the clothes in colour bands

and size order, with matching pegs:

A Romany rag tree

A Tibetan flag

Your patterning in me. 


\section{Forensic Jumper}

(For Jenny and Mathew in London)

You return my French designed,

Italian wool jumper,

Animale, by Roger Duc,

after I rejected it,

too heavy for the flight home

to summer.

Now, unpacked, unwashed,

it traces northern nights, dark, long,

yet threaded

with metallic light.

There's a whiff;

dark slime

wintry footpaths,

fire smoke

crisp air.

On the sleeve, a daub,

warm beer, spilled in laughter.

In front, a scab of milky sauce;

some not especially game bird

poached in cream and wine.

Hairs of an antipodean cat

spike out, three-toned

and, on the shoulder,

two of my hairs,

six months younger then.

Doubtless, too, residues of skin or scalp

around the neckline

could be scraped or plucked,

sent to laboratories:

all evidence of happy times. 


\section{Swansong}

(For Pamela Gray) ${ }^{1}$

Today, for you, I braved a storm.

Glutted gutters,

rain swept,

wind poured all over me

and the streets of my town.

Leaves locked on pavement

rubbish brushed at knees

litter collected cowering in corners.

And then you burst upon us

full sun-red, yellow-lined, blue-eyed you-

brandishing your eyebrows

winding up your voice

sliding down your 'cello

to make your swansong.

Ah, no swansong here, my friend-

more full-throttled, pounding,

new-hatched energy!

Homing,

I shrugged off the storm

like water off a duck's back.

\section{Endnote}

1. Pamela Gray is a New Zealand 'cellist, singer and composer, whose work Swan updated Saint-Saëns' The Swan, dying from an oil spill and pollution. 


\section{Research statement}

\section{Research background}

These three poems are dedicated to people the author knows (or knew). All use the idea of a conceit, which is commonly defined as an extended metaphor and is most closely associated with the Metaphysical poets like John Donne, in the Seventeenth Century, who often attributed spiritual qualities to earthly objects, or vice versa. Herz has argued that, 'Metaphysical poetry argues; it is complex and intellectual, and it depends on surprise (but in Donne's case, a surprise that the poem often makes true). Dexterity, inventiveness, the pleasure of and in the word, and the fusion, often exorbitant, of the carnal and the spiritual, of body and soul: these are certainly the essential ingredients of metaphysical wit' (2006: 105). The pun in the title, Three physical conceits, is an allusion to this metaphysical tradition.

\section{Research contribution}

These poems offer a contemporary approach to the extended metaphor, playing more with friendships rather than courtship, and mundane objects and events rather than cosmic or spiritual themes. While seeking to be witty, these poems attempt to domesticate the device and avoid overt argument or complexity, concentrating instead on expressing affection through conceits of obsessive order, forensic investigation and clichés from bird life.

\section{Research significance}

These poems have been blind peer refereed and published in a major journal of creative writing research.

\section{Works cited}

Chapple, G 1981 'Pleione' Art New Zealand 19, at http://www.artnewzealand.com/Issues 1 to20/pleione.htm (accessed 10 September 2015)

Herz, JS 2006 'Reading and rereading Donne’s poetry’ ed A Guibbory, Cambridge UP, London Lodge, M 2014 'Summer of euphony' in Jack: A Festschrift for Jack Body eds J Shennan and J Exley, Steele Roberts, Wellington, at http://researchcommons.waikato.ac.nz/bitstream/handle/10289/9456/Lodge_2015_Summer\%20of\%20 Euphony.pdf?sequence $=5 \&$ isAllowed $=y$ (accessed 10 September 2015) 


\section{Independent scholar}

\section{Julia Prendergast}

\section{Everything that matters is silvery white}

\section{Biographical note:}

Dr Julia Prendergast is an independent scholar, with a $\mathrm{PhD}$ in Writing and Literature. Julia's stories have been longlisted, shortlisted and published including in: Lightship Anthology 2 (UK), Glimmer Train (US), the Séan Ó Faoláin Short Story Competition (IE), Australian Book Review, Elizabeth Jolley Prize, Canary Press, TEXT, Meniscus, Bukker Tillibul, the Boroondara Literary Awards, and Writing from Below. Julia's fiction is also forthcoming in Island Literary Magazine. Julia's theoretical work has been published locally and internationally, including in New Writing (UK) and TEXT.

Keywords:

Creative writing - temporising - metaphor - narrative 
Sarah is leaving him.

It is to be expected but $\mathrm{Al}$ does not expect it. He calls his wife a $\mathrm{Ho}$.

He doesn't raise his voice. He says: Ho. Holmium. Chemical symbol Ho. Phonetically slang for slut.

Sarah says: You see! You SEE!

Holmium looks like crushed tin foil. It strongly absorbs neutrons.

Sarah is crying steadily. Is it any wonder?

Holmium is used as a burnable poison in nuclear reactors.

For fuck's sake, Al.

He makes a note of the swearing: the placement of it, the emphasis, the angular relationship between the swearing and her sadness - No - her frustration.

He sits in the leather chair, rubbing his fingers over the silver studs - Grey. Oxidised.

$\mathrm{He}$ is not there with her, in time. He is lusting after the silvery white, when he was desperate for more than not-so-much, when the moon was dark and luminous.

Al and Emily head out of the school grounds, down the pathway lined with lemon scented gum trees.

Al stops abruptly. I forgot my Chemistry book, he says. He drops his schoolbag at Emily's feet. Wait for me, he says, turning towards the school building.

Potassium, says Emily, dropping her bag beside Al's.

What?

Potassium, she says. Her voice sticks in the still air, thick, like the lemon breath of the gums. She picks at the jagged remnants of red nail polish. Al watches her fingers, thumbnail against thumbnail. He forgets the chemistry book. Her white knuckles are exposed in a vertical line, like moons, separated by shady hollows. Her thinking is luminous, like the moon, and he's floundering somewhere in the hollows, gasping after her elsewhere thoughts.

Emily brushes her nails against the hem of her school dress. The red flecks sparkle against the hem, against her lean, bronze thigh. He thinks of rainbow trout: the fresh, wet pelt.

She looks up suddenly. C'mon Al, she says. Potassium. Chemical symbol K. I'll wait for you, $O \mathrm{~K}$.

$O$, says $\mathrm{Al}$.

O. Oxygen. Chemical symbol $\mathbf{O}$ 
O. Spherical like the moon, ripe and luminous.

He doesn't mention it, the chemical correlative, and he doesn't mention the moon either. He doesn't let on that he lusts after her thoughts.

$K$, he says softly. Potassium, he adds smiling.

Hurry up Al. RUN! I'm counting to fifty then I'm out of here.

Yes, he says gasping, turning and obeying, running towards the school building, sucking the air greedily. The air sticks in his throat, thick, like her shady voice. He thinks of anaerobic organisms. Ao's. They don't need oxygen to survive; in some cases oxygen kills them. Reaching into the locker, he wonders if Ao's could survive on the moon. Oxygen is not held to the moon as an atmosphere. It's all about the ability to adapt.

He rushes back to Emily - book in hand, out of breath, pins and needles in his throat like the killing type of oxygen. He zips the book into his backpack and loops the straps over his shoulders. Still puffing, he says: Do you think anaerobic organisms could live on the moon, you know, because the oxygen is bound up in chemicals?

School's out freak, says Emily smiling, a speck of nail polish on her lip. He reaches towards her mouth and she draws back, flinches.

The red, he says.

She puts her fingers to her lips and they walk on in silence. He looks down, keeping pace with the swish of her hem.

It's almost impossible to believe that the moon has no inherent silvery quality. That it's actually...

\section{Fuck Al. Walk. Don't talk.}

Potassium, he says, noting the swearing, mapping its place.

Sauntering beside Emily, he can smell his boy-sweat, afternoon bitter; he can smell the slovenly tang of the lemon-scented gums. Above all else, he can smell her skin, wet and new like a clean tongue. If the moon is dark and luminous, then a smell might be luminous too, even ultraviolet or infrared. It seems possible.

Emily's smell puddles around her collarbone. The collarbone is the only long bone in the body that lies horizontally. Emily's smell puddles there like luminosity, wafting his way on the late spring breeze.

Emily Roberts. She abbreviates it: E.R. She marks everything with her initials rather than her full name.

Her chemical symbol is Erbium. Er.

When it's artificially isolated, erbium is silvery white like the moon. Pure erbium is malleable; its salts are rose coloured with fluorescent properties, ultraviolet absorption bands. 
Al used to get erbium confused with herbium. Chemical symbol Y. Phonetically confused that is: he understands their make-up precisely. It's just that $H$ is little more than breath, slippery, like the water across the rocks in the gully creek ... where the touching began.

Emily instigates the touching in the breathless gully of the smooth rocks, during the last months of their last year of school. It's all pink rose crystals and ultraviolet absorption bands. Al would have welcomed the touching sooner, of course, years sooner, but he waited for her to start it. That's how it was and must be, primarily because of botulism.

Botulism blocks the nerve impulses. It causes paralysis. It can be fatal.

Anaerobic bacteria produce botulinum toxins; that's how it starts. The toxins can be ingested via food that is improperly processed. The toxins fester in anaerobic conditions, in time not oxygen. How else does the black moon become silvery white? By mirroring the sun in luminous time. We have to step outside time to see that the moon is shady.

Food that is bottled or canned at home is a concern because there's not enough sustained heat to prevent germination. Beware home-bottlers and home-canners. That can't be so many. Who has the resources to seal an aluminium can at home?

Aluminium. Chemical symbol Al.

Aluminium is remarkable for its ability to resist corrosion. It is highly chemically reactive. More so than not so much. Aluminium is soft and durable, lightweight. It is ductile and malleable, silvery grey.

Ductile. Like tactile. Phonetically. Not connotatively. Chemistry does not care for connotation. Ductile is not a word that Al has heard outside its chemical context. Maybe it's there in real time but he only knows it in the story of aluminium. Wet-earth gullies. The shady hollows of her luminosity.

Ductility refers to a solid material's ability to deform under stress. It's like malleability, more or less, which is supposed to mean pretty much or the same, except that more is not the same, and less means that the moon is shady.

To prevent the germination of botulinum spores, aluminium tin cans may be heated to $85^{\circ} \mathrm{C}$ for five minutes. A tin can is a tin can, of course, and a man is a man, but a man was once a boy and his mother never touched him. He has no memory of ever being cuddled or kissed by his mother, and that leads him to thoughts of botulism. Black moons.

In the gully of smooth rocks, in the luminous puddles of her smell, Al doesn't think about botulism and black moons. Afterwards, in the hollows, he is reminded that we don't need so much. He is aware that the gully is not a necessity. He has lived many moons without the touching.

In the gully everything is silvery white and lustrous, clear and luminous, and he thinks that everything that matters is silvery white. Erbium and Emily Roberts. Whispering wash on smooth rocks. Shiny tin cans and the luminous moon. He also knows that we 
don't need everything that matters. Desire doesn't have to be reciprocated. It is not based on mutual magnetism. Even dysprosium is silvery white.

Dyprosium. Chemical symbol Dy.

Dy. Phonetical equivalent Di. His mother's name. That's all he ever knew to call her because she wouldn't have Mum.

I can't abide it, she said. Abide. Only his mother uses such words in the everyday.

Dyprosium is a rare earth element with a metallic silver lustre. It is never found in nature as a free element. It is greatly affected by even small margins of impurities. Along with holmium, it has the greatest magnetic strength.

Magnetic strength is one thing, of course ...

Al and Emily are drawn to the gully. Every day, on their way home, they pass through, barely talking. The gully is saddled by iron bark gums and damp, dark earth. It is council land, protected. Emily always pauses before descending. She looks around for observers, witnesses; it's part of her pre-descent routine.

Today she lingers for longer, eyes darting, fingers busy at her hem. Al reaches for her waist, for the inner hollow of her hip.

Not up here, she says.

Emily clenches her hem, clenches and unclenches ... because of his hands at her waist in real time.

I have to go home, she says. ... Fuck's sake.

Al doesn't swear. He never feels the compulsion. He pays particular attention to the swearing, to the context and the emotion, if he can decipher it. He undertakes some research, reading, searching for the impetus. Apparently swearing can be used for pain relief. People who don't swear all the time can use swearing to tolerate pain. They can withstand the pain for longer if they swear. It sounds utterly ridiculous at first but he reminds himself that the moon is black and silvery white.

When Al arrives home he goes straight to his room. He stretches out on his bed for a long while. He fiddles with the blinds, altering the light, shifting slats of twilight on the dank white wall.

Fuck, he says. Fuck! Fuck! Fuck!

His mother gasps from the hallway. He knows what she thinks. She thinks he's masturbating. If she hears fuck, he must be thinking about fucking. She thinks literally, like a spider. She doesn't see that black is luminous. She thinks children need food, not cuddling. She thinks children need clean clothing, not touching.

We don't need so much, she says. It's her mantra. She says it all the time - after dinner as she clears the plates, as she seals the bottles of tomato relish, as she hangs clean clothes in his wardrobe. Sometimes she abbreviates: Not so much ... 
He barges out into the hallway so she can see there's nothing stiff, nothing sexual. He holds his arms wide, palms outstretched, fingers touching the hallway walls. She scurries down the hallway on her busy spider legs, back to the kitchen.

He follows her, calling after her: Di. DI!

He stands beside her in the kitchen. She takes the speckled rainbow trout, fresh from the market, and lays it on the chopping board. She takes her big kitchen knife with the wooden handle, positioning the hefty blade under the gills, hands poised momentarily and then crunching the knife through the neck, firm, fast and steady, slicing the head off on the diagonal, exposing the pale pink flesh, such an unexpected shade of pink beneath the freckled rainbow skin. She puts the fish's head aside on the newspaper.

He says: Apparently swearing increases the pain threshold...

Swearing is unnecessary.

I know you can't abide it, he says.

Abide? Unnecessary is unnecessary. ... She scoffs: What pain?

The water. The shallows. Cold wash on smooth rocks. Twilight slats.

He stares at the fish head. He folds the newspaper to cover the eyes, glassy and dumbstruck.

The more time he spends with Emily, the more he thinks he is getting closer to her thoughts. Time and knowing increases the luminous reflection of her elsewhere thoughts. It's not like a mirror. The image is not clear. Luminosity is bright and shadowy together. He has passed the point of literal knowing and he wants more than not so much.

The next day, they go back to the gully. They are at ultraviolet, near infrared, when they're interrupted - leaves crunching under school shoes on higher ground. He hears the leaves and then the laughing. He wants to finish but she hitches her undies, crying, panting. She yanks her school dress down.

Al hitches too, collecting his jumper from the ground after she stands. They walk home in silence but he's not paying attention to the quiet. He lets his shirt hang loose, thinking of black moons and willing it to die down.

There is no warning that it's over. He is not blind. Dead fish are blind. Time is blind. There is no warning. If the sniggering or the crunching leaves were the sign then he missed it. If his hand near her hip was the catalyst then why return the following day, the days after?

The first sign, as far as Al can see, is the timber bench, bookended by plastic buckets, overflowing with booze. Everyone is there, celebrating. School's out. Forever. Freak. It's not just the bench of course - it's Emily, on Tommo's knee, her arm swung around his neck, as if intimacy is nothing more than the punch bowl on the table between them.

Al starts downing the punch, vodka and tequila mostly, sweetened with pineapple juice 
and orange fizz. He can't walk away while she's sitting there on Tommo's knee, and if he's going to watch, he will drink and be drunk, watching. Everyone's mashed. He fits right in.

He sits directly opposite Emily. Her right knee lolls outwards so he can see her undies, black and silky, his favourite ones, and her thighs. He was with those thighs when they were awkward and desperate, like a child with a mother who doesn't tolerate touching.

Al guzzles punch until he's desperate to piss. He staggers upstairs to the ensuite bathroom, for the quiet. He can't aim properly and he makes a mess of things. He tries to clean up with the shaggy blue bathmat. It's all too much, the bending and standing, the shag pile blue against the smooth grey tiles, incompatible textures, the chirpy blue.

He vomits until there's no more vomit. He retches, then, and cries. Peristalsis, he whispers. It's okay, he slurs, slippery words. A normal physiological reaction, under the circumstances. He sits on the floor, resting his head against the tiled wall, cool porcelain against his cheek like a smooth river rock. He closes his eyes and yesterday is now, in the touching gully ...

He hears Tommo laughing. He hears him say: What about Al?

Al stands. He peers through the crack in the sliding door. They are standing against the wall, diagonally opposite, Emily's hand in Tommo's jeans.

She says: What ABOUT Al? She is talking in her sex voice and he is drawn in for a second until his eyes and ears start to work together. Her voice. Tommo's stiff.

Al's a dippy, dippy downer, she laughs. A dud root, she adds, working the hand.

Al watches on and he knows, with a glinting certainty, that he's not luminous. The knowing is wedged firmly under his gullet. Wallowing in her luminosity, he had forgotten about the energy lines, reciprocity and magnetism and not so much. The shady hollows.

Al opens the sliding door, startling them like crunching leaves. He enters the dim room like he's taking centre stage, under a luminous spotlight. The moon is black, he says, addressing Emily. He articulates his words precisely, edging towards sober, only slightly giddy. He lays the stresses like he's been practicing his lines for weeks. The moon has an atmosphere but it's too thin to breathe. He is encouraged by the steady rhythm of his voice. Although the moon appears to be bright, its surface is actually dark, like worn asphalt, turning the sun's rays silvery white.

What the hell? Emily's hand is still now but it remains there, in Tommo's jeans.

Holmium, he says. He doesn't yell. He has no oxygen for yelling.

Holmium - chemical symbol Ho - phonetically slang for slut.

Emily withdraws her hand, leaving Tommo wide open. 
Holmium is a rare earth element, soft and silvery white. Holmium has the strongest magnetic properties of any element. Only dysprosium comes close.

Think I'll go and get a drink, says Tommo, trying to zip up.

Al continues, crying quietly but maintaining control. His voice is strong and sharp and holds its shape. Trivalent holmium ions have fluorescent properties, he says, focusing on Tommo's hands, the small flashes of light from the zipper.

Tommo and Emily snatch a glance. Tommo laughs briefly, shaking his head and blowing air like he's blowing cigarette smoke. Tommo turns to Emily. See you downstairs?

Al marches to the door, determined to be the first out. It's not potassium, he mumbles in a hollow whisper, brushing Emily's shoulder as he passes.

On the way home he swears. That's all he knows to do.

Fuck. Fuck. Fuck, fuck, fuck.

Yesterday is so close he can smell its luminosity.

Sarah is leaving him.

It is to be expected but $\mathrm{Al}$ does not expect it. He calls his wife a $H o$.

He doesn't raise his voice. He says: Ho. Holmium. Chemical symbol Ho. Phonetically slang for slut.

He sits in the leather chair, rubbing his fingers over the silver studs - Grey. Oxidised.

He is seated and Sarah is standing. He is completely still but for the hands. There's plenty of air to breathe but he tastes toxins. Conscious, fully cognisant, he is rigid - eyes alive and gone, alert and glassy, like a dead fish.

She says: I'm sorry Al. She cries: You don't NEED people.

You cannot abide me, he says steadily.

Abide. It's not about-abiding. It's ...

The silvery white. Yes, he says. It's not so much. 


\section{Research statement}

\section{Research background}

When Jared Diamond asked acclaimed evolutionary biologist Ernst Mayr why Aristotle didn't come up with the theory of evolution, Mays answered frage stellen or 'a way of asking questions' (ABC 2013). The idea that a particular way-of-asking might generate a particular way-of-knowing is applicable to the practice of creative writing. Modjeska unpacks the concept of 'temporising' (2002: 75), inviting us to consider the generative possibilities of the temporising space - as an imaginative space for writers - a way of asking questions.

\section{Research contribution}

This work enacts the concept of temporising at the level of form and content, interrogating the connection between language and imagery, and the work of association and similarity and, following Aristotle, recognises the temporising space as a metaphorical playground. This method of asking questions involves alogical processes of association: supporting Freud's 'reciprocal relations' between dissimilars (1900: 404) and Froeschels' observation that 'the subconscious [mind] considers similarity identical with identity' (qtd. in Mavromatis 1987: 178).

\section{Research significance}

This work uses Modjeska's analysis, and theories of subconscious processes of association, to enact an inquiry in the performative narrative space of the short story. It has been longlisted for the Australian Book Review's Elizabeth Jolley Prize (2014) and the Séan Ó Faoláin International Short Story Competition (Ireland) (2015), and was also a finalist in the Glimmer Train International Fiction Open Contest (USA) (2015).

\section{Works cited}

ABC 2013 The book club 1st aired 10 September 2013

Freud, S 1900 'The interpretation of dreams', in J Rivkin and M Ryan (eds) Literary theory: an anthology $2^{\text {nd }}$ ed, Malden, MA: Blackwell, 397-414

Mavromatis, A 1987 Hypnagogia: the unique state of consciousness between wakefulness and sleep London: Routledge

Modjeska, D 2002 ‘Writing Poppy’ Timepieces Sydney: Picador, 67-94 


\section{Latrobe University}

\section{Karina Quinn}

\section{How to disappear in your name}

\section{Biographical note:}

Dr Karina Quinn is a researcher, writer and poet whose work lies at the nexus of feminist and queer theories of the body, autobiography and philosophy. Her book, all the beginnings: a queer autobiography of the body, will be published in November 2015 by Australian Scholarly Publishing. Quinn is a Lecturer in Interdisciplinary Foundation Studies at $\mathrm{La}$ Trobe, and founding editor of Australia's only interdisciplinary, peer reviewed, gender, sexuality and diversity studies journal, Writing from Below. She is currently working on a psychogeographical history of a body of water near her home in Melbourne.

\section{Keywords:}

Creative writing - creative writing as research - naming - autobiography - metonymy - poetry - heteroglossia - text 
Loving: keeping alive: naming.

Call yourself. Give, yourself, names.

Hélène Cixous Coming to writing (1991: 2)

PK: PK in the dark in a big big house with SO many stairs and she climbs up them one foot two feet one foot two feet she stops at each one her hand barely reaches the peeling bannister her room is at the top of the stairs her room that she shares with her sister with its glass doors that look through to her Mum. With its glass doors that look through that she aches through that she can and can't see through to her Mum.

\author{
body under blankets \\ sunk into mattress \\ she feels the floor \\ against her hip \\ the thinness \\ of morning
}

PK in the morning with her sister behind her going down the long long stairs and when she gets to the bottom she is in the lounge-room with her sister behind her and the old red rug is covering the cold cold floorboards and on the old red rug lies a person who is not moving very much at all just an in out in out in out of breath a beer can near an outstretched arm the smell of ash and yeast in the morning she steps over the arm her sister steps over the arm she goes into the kitchen and gets two little wooden bowls her favourite ever bowls and tips in muesli and milk and together, in the ash and yeast and breath, on the old red rug, they eat.

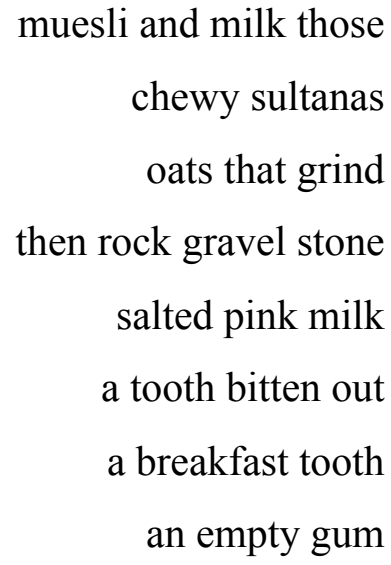

PK in the daytime in the corner of the playground where the sandpit is where she gets a bucket of water and a bucket of sand (a blue bucket of water and a red bucket of sand) and she adds slowly slowly the water to the sand and she mixes and mixes and 
adds and adds until she gets perfect sand sand to build with sand to touch gravelly and moist sand that will make houses and humpies and turtle shells and flippers sand that will sculpture the world.

in the corner

there is shade

the others run

the others chase

the others scream squeal the thrill

of being caught

in the corner

the shade keeps the sand

wet graining sculpting

making her

making home

PK in the afternoon after lunch when she didn't like the peas but she wouldn't get the little cardboard tub of ice-cream with its perfect wooden paddle that felt grainy on her tongue unless the peas were all gone so she put them in her mouth and then stored them in her cheeks one by one then went into the toilets with the long long silver sink and spat the crushed green balls out and it was the naughtiest thing she'd ever done and she ate the ice-cream and scraped the paddle on her tongue and then hopped onto her mat and got pat pat patted to sleep by her favourite childcare worker and she slept with a cold belly and a wood feeling on her tongue.

pale wood paddle

thin delicate caress

a tongue that sweeps

its surface to find

pine

breath

sugared blood

soursweet

depth 
PK in the dark in the sun it's late they kept saying but she can hear the people walking and see the streak of light under the curtain and birds and everything out there in the sun in the sun in the going down sun.

light stripped

of warmth comfort

coming from heels on concrete

magpies

metal striking metal

all that work

voices

talking away time

waiting for darkness

for deepening breath

for caress

BELLA: Bella is the sister-name the one she is called by when needed when loved when wanted for opening jars or reading that story Bella, please, that one. Bella is soft she is kind she makes her bed into a nest for her little sister to curl into she stirs porridge in the morning and adds honey and milk. She keeps the sweet thick feel on her tongue for most of the morning (her oaty breath) and then finds her sister at recess and lunch. She sits with her on the long cold silver seats that leave lines on the backs of their thighs. She peels mandarins. She unwraps greaseproof paper from around sandwiches. She takes their rubbish to the short loud bins.

the lines on the backs

of their thighs

below their blue and white

school dresses

are red

striated

when they stand

their skin is music stave

letter practice

repetition

when they stand 
their skin

is read

Bella is the only one her sister will speak to when she wets herself at school. Four. Her sister is four and has started school early and believes everything she is told. When she is told she is not allowed to ask to go to the toilet in class time because she should have done that at lunch she holds and squirms and squirms and holds and then feels hot wet the trickle down her leg the puddle on her little red plastic chair and she stands and she runs to the toilets and goes in and locks the door and won't come out.

grey everything is grey and why is it always so cold in the blue mountains where we are without our mum and the door will not keep enough out

Bella is called from her class where she is learning how many days are in each month (all the rest have thirty-one except for February alone) and she goes to the toilets and drops to the cold tiled floor and slither scoots under the door. She undresses then dresses her sister who will speak to no one else. Spare clothes that the teacher has handed her: blue corduroy overalls, a white t-shirt with orange flowers, a scratchy green jumper. No socks. Her sister spends the rest of the day with bare feet inside her moist shoes. But she does come out, holding Bella by the hand, pigtails skewed from the jumper being pulled down over her head, her ankles showing, her fingers bluish from the cold.

we keep each other nested in the cold we spill stories in the night light-filled we keep each other

FRANCIS: Francis is the name she chooses for herself when she is twelve. I didn't give you middle names, her mother says. I thought you'd rather choose them for yourselves. She tasted the name it sounded like books like Narnia like Mr Tumnus might show up sweltering in a Sydney summer, his parasol no match for the sun. Francis is the name she calls herself; she tries and fails to get others to say it aloud so 
at night, under her blue and white striped sheet, two fingers inside herself, pushing at her own edges, she whispers it, after her sister has gone to sleep.

she couldn't go deep

enough

it didn't matter how hard she

pushed

she couldn't stretch wide

enough

couldn't fit enough in

bone traced

fingers without length

the way it feels to never

have enough

reach

STEVIE: She picks Stevie because of Stevie Smith. Because her Novel on Yellow Paper (1937) is the spine on her mother's bookshelf that always draws her eye. She doesn't read it, but she takes the name, insistently. She will make them say it. She will force the name down and out of her loved one's throats. Her friends do. They take the name up with glee. But her sister and her mother refuse. So at school, she is Stevie. Stevie is black eyeliner for lipstick her lips turning her mouth into a red wet cavern lined by a matt night sky. She is thick black tights, stolen silver rings on every finger and each thumb, doc marten boots. She is open-wide take on anyone terrified under tough. She reads Sylvia Plath who writes 'the blood jet is poetry' (1963) and one night, walking down an alley in Erskineville, she learns how to bruise bleed her knuckles by slamming her left fist into fences and walls.

blood doesn't jet it seeps

it leaves traces

on brick, on iron, on wood

it pushes up

through the bandage weave

it holds the wound

redly open 


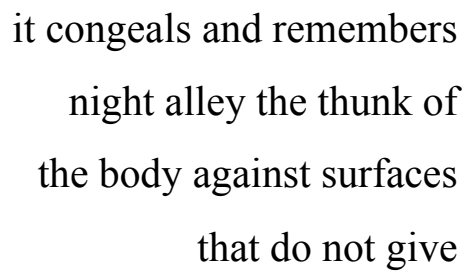

RAYNE: This name, she takes for anonymity, for disappearing, for the way that heroin turns each day grey. Rayne is only comfortable when she's emptied out. She is legs spread for her lover, she is arm open always to the wind, to steel. She is what she can sell next (books, leather chaps, saxophone, flute, mobile phone, oil paints, herself).

$$
\begin{array}{r}
\text { morning is hunt sell buy } \\
\text { acrid powder sizzle } \\
\text { shoot } \\
\text { shoot the day } \\
\text { find love } \\
\text { find nearness } \\
\text { find warmth } \\
\text { try to read } \\
\text { to write } \\
\text { to make a story } \\
\text { from abject fluid } \\
\text { from wanting } \\
\text { from what a room looks } \\
\text { like coming } \\
\text { down }
\end{array}
$$

PERSEPHONE: Persephone lives in Rayne she is the dungeon worker she treads through room after room; a magic box that holds her in while men knock at the door and ask her for everything. Persephone is the name the men say without irony. Come here, lay down over my knees, don't call out, no one will come, be still, don't struggle, but moan.

SARAH: Sarah lives after Persephone. After rooms with no daylight after being always held. Down. Sarah lives in a different series of rooms plastered with mirrors and on the bed, too many towels. She uses and washes and uses and washes and hangs red white red white red white blue towels. Sarah is 
lingerie and wobbling in heels, she is open, she is waiting for money, for men to get off her, for the way her body feels after the weight of them is gone.

Rayne is keeper and kept. She is trying-to-write. She takes a huge clay cup of peppermint tea and a cigarette out to the overgrown garden and balances a journal on her lap. She imagines what it would be like, to write. To make text. She picks up her pen. She writes that she is trying to write. She smokes. Tea turns her throat hot. She writes that she wishes she could write. In the garden she thinks about Persephone and Sarah and imagines them gone.

from over the fence the sound

of a kettle

boiled

from over the fence the sound

of a life without

a magic box

of rooms

from over the fence the sound

of a person with only

one name

KARINA: Karina is detox with two garbage bags of clothes and a set of juggling clubs and enough money from her mother for three phone calls measured out in twenty-cent pieces.

under the shower

is where the body

finds relief

the hot sting of water

pelts

and washes bile

spit

shit

away

under the shower 


\author{
she stares at the open \\ hole in her arm \\ and sings her dealer's \\ phone number \\ but he doesn't \\ come
}

Karina is meetings, meetings, meetings. There is a script that they follow and it comforts and terrifies simultaneously. God. The word, the thing, the naming, the grappling, the trying to let in. It takes her ten years to refuse higher power, divine intervention, being kept clean by a beneficent being. It takes her ten years to move out of all of those rooms, filled with circles of people, helping each other to get or to stay clean. And then? Karina is writing.

when no god decides

which bus she will catch who lies flayed on an open road

while others sail past

to lunch

to work

to home

no god decides

which name she takes

what person that name makes

no god decides

which words she places

for you to read here

MAMA: Mama is who comes next. Made in the blunt vice of birth, through muscle and blood and milk and bone. Made in the sound of her children's voices saying her name, in playgrounds, next to change tables, on her knees picking up toast crusts and mandarin segments. Made in the dark, in nights of nodding off in a breastfeeding chair, sleeping while her babies sleep. Made in grimace, and frustration, and comehere-go-away: in love. 
bitten

these children

want

to tear her

apart

then put her back

together

they bang

their bodies

against hers

they grab

hair

lip

ear

they push pull

they insist she notice

everything

When her oldest boy is two-and-a-half, and her youngest isn't even crawling yet, she tries to get them both out of the house. The baby is dressed and changed, she has a bag packed with rusks and water and fruit and spare nappies, but the toddler is still in his pyjamas. Stripey. Cotton warm. Cosy from the night. She has his clothes in her hands, she is asking for him to come closer so she can take off his pjs and put on his pants (one leg, two legs!) but he runs. He runs from her and the baby starts to cry and he laughs and runs and laughs so hard he gets the hiccups and she is saying please please please please.

when babies

cry

the world telescopes

down

to that one wail

to needing it to stop

to be solved

to be quiet 
when babies

cry

nipples leak milk

and although there's nothing

wrong

it is all wrong

when babies

cry

there is no

way

out

She stops trying to get him to come voluntarily and instead grabs him as he runs past. The baby is still crying. She pulls off his stripy warm pants. He is struggling. He yells no, repeatedly. She asks him to step into his jeans (one leg, two legs!) but he will not. He pulls against her. The baby is still crying. He pushes at her. Crying. She picks him up and tries to pull his pants on that way, while he is in the air. He struggles and yells. Crying. She yells, her voice a desperate loud wobble, please help me! And then she drops him. She doesn't realise he is quite so far from the ground. He doesn't land on his feet. They slip out from under him and he falls, his head smacking against the floorboards. They all cry. She tries to hold him and the baby. She says sorry. A year later, he finally forgets.

forged

she is forged

by her children

by the whitered

flashes

of rage

by the endlessness

of days

by the way they sleep

unfolded

their lips

plumped 
their legs

splayed

by the drawings they make

bubble belly

sticks for arms

never a neck

enormous grins

made from a single line

this is you mama they say

this is you

QUINN: Quinn comes after the first book is written, after the hysterectomy the surgeon said she had to have (fast growing fibroid, vascular, the weight above her cervix, incontinence), after she couldn't stay at one end of the gender binary anymore. Quinn takes her last name as her first, but keeps her whole name for her writing, for her work. Her partner says I can't call you that honey. It's too harsh. Her friends and colleagues try to remember, and some of them do better than others. Her children call her Mama, or Mum, or Karina, or Dr Mama. In the beginning it feels important for all of them to call her by her next chosen name, but she doesn't insist. She waits. She writes. She slides. She ceases the hunt for the next name. She takes them all. She is PK/Francis/Stevie/Rayne/Persephone/Sarah/Mama/Karina/Quinn. She takes them all and holds them inside her skin. She is all names, for herself: she is no one named.

body under blanket

gaps in gums

gone

the mattress is

off the floor

the children

unfold

writing is written

baths are taken

each name

holds

its own 


\section{Works cited}

Cixous, H 1991 'Coming to writing' and other essays, Cambridge, Mass: Harvard University Press Irigaray, L 2002 To speak is never neutral, G Schwab, trans, London: Continuum

Plath, S 1963 'Kindness' in T. Hughes (ed) Sylvia Plath: Collected poems, Great Britain: Faber and Faber

Smith, S 1937 Novel on yellow paper: or, Work it out for yourself, New York: Morrow 


\section{Research statement}

\section{Research background}

In Autobiographics, Gilmore writes that 'insofar as autobiography represents the real, it does so through metonymy, that is, through the claims of contiguity wherein the person who writes is the same as the self in the writing; one extends the other, puts her in another place' (1994: 67). This contiguous notion of autobiography and truthtelling continues to frame discussions of lifewriting, and is disrupted by experimental and fragmented autobiographies such as Cardinal's The Words to Say It (1983) and Brossard's Intimate Journal (2004).

\section{Research contribution}

By creating a non-traditional heteroglossic text, where the voices of the many come from the body of the one-who-writes, and are continuously interrupted by the use of poetry as a spacing device, this work extends a tradition of experimental autobiography.

\section{Research significance}

This work is significant in that it draws attention to Gilmore's 'technologies of autobiography' (1994: 46) through the creation of a fragmented and interrupted text that asks the reader to question notions of truth and fixed identity. It also continues the valuable Feminist tradition of troubling the genre of autobiography as a coherent and singular telling of a life through a heteroglossic and poetic approach to the question of who speaks.

\section{Works cited}

Brossard, N 2004 Intimate journal, B Godard (trans), Toronto: Mercury Press

Cardinal, M 1983 The words to say it: an autobiographical novel, Cambridge, Mass: VanVactor \& Goodheart

Cixous, H 1991 'Coming to writing' and other essays, Cambridge, Mass: Harvard University Press

Gilmore, L 1994 Autobiographics: a feminist theory of women's self-representation, New York:

Cornell University Press 


\section{RMIT University}

Francesca Rendle-Short

Parsing the aside (the poetics of immersion and patience as dialogue)

\section{Biographical note:}

Dr Francesca Rendle-Short is an Associate Professor in the School of Media and Communication at RMIT University. She is co-director of the nonfictionLab research group and the Writers Immersion Cultural Exchange (WrICE) research program. She is an award-winning novelist, memoirist and essayist, and author of the critically acclaimed memoir-cum-novel Bite Your Tongue (Spinifex). Recent scholarly work has been published internationally in NANO: New American Notes Online, The Essay Review (University of Iowa), New Writing: The International Journal for the Practice and Theory of Creative Writing and Life Writing, as well as TEXT and Axon: Creative Explorations. Her creative works have been published widely, including in The Best Australian Science Writing 2013 (NewSouth) and Overland. She was an International Writing Fellow at the Nonfiction Writing Program in the Department of English at the University of Iowa in 2013 and her research was showcased in 2015 Outstanding Field: Artistic Research Emerging from the Academy, Victorian College of the Arts.

Keywords:

Creative writing - writing process - material thinking - collaboration - creative work 
Context: How can we review, scrutinize or examine other people's works in the academy, especially those that are creative works? What is the process of assessing looking at, responding to, being with - creative product? And how might this 'being with' manifest itself in writing?

Could it be that in responding to these works we make academic written art? In other words, can we make new creative work, to fulfill the aspirations of creating creative works within the ERA academic context, out of the examination of creative work? One begetting another: makings of a similar kind?

In this parsing exercise, 'Parsing the aside', a writer-and-academic is invited to respond in writing to the visual work of a visual-artist-and-student-academic in exhibition. What follows is an account of the process as writing experience, replete with pause, reflection, improvisation; considered reflexivity, digression, resistance, repetition, proposition, and echoes of ekphrasis.

If I had a dictionary. If we had plasticine. If we could dance. Oh if we could fly.

The method is in the making: being with and responding to as creative method. Immersion. And patience.

In the process of this making by passing 'the shuttle of creative vision back and forth' things become possible, we are changed (Carter 2004: 5), our process inscribed by language. We make (cause something to exist or come about); in this case, make something with and between the page and writings of the iPhone 5 and drawing, object and mixed media of the exhibited works, shared coffee and all. Thinking as thinking, in other words, not representational of processes but 'thinking in action' made concrete in poetic notes (Blythe 2011: 36). We allow language to speak from a place 'crawling with secrets which give way to thought'; make it say what it keeps in reserves which in the process of writing 'also makes it come out of its reserve' (Derrida on Cixous, in Sellers 1994: vii).

Background: Martina Copley's exhibition of seven works, entitled 'The movement of the aside', investigates uses of the aside as a way to discuss the movement of making. Copley (visual-artist-and-student-academic) considers variations such as listening, disenchantment, lightning, grasping and annotation. The seven notes-as-asides in this parsing exercise, 'Notes to $\mathrm{M}$ ', written by me as writer-and-academic, are in specific response to her invitation to participate as 'respondent' to this exhibition of work, an annotative process of sorts.

Process: There were a number of constraints to this invitational immersive and creative exercise, including: the allowed time (about an hour between the exhibition being hung and opening), the hardness of the concrete floor (the provision of two embroidered cushions for the writer-and-academic to sit on), and the question of how to deliver any possible response (is it better to use pen and paper in a notebook to give ex post facto, or scribble notes and leave a trail of thought - asides - across the concrete floor?). To exercise the aside as aside this writer-as-academic followed 
Jennifer Roberts' example in 'The power of patience' (2013) of engaging in 'deceleration, patience, and immersive attention', to give thought, contemplation, eyeing time time in order to allow 'details and orders and relationships' to emerge:

[J]ust because you have looked at something doesn't mean that you have seen it. Just because something is available instantly to vision does not mean that it is available instantly to consciousness (2).

Note: 'Notes to $\mathrm{M}$ ' were composed directly onto an iPhone 5S Notes app using keyboard and fingers, and sent to Martina Copley by email (the visual-artist-andstudent-academic absent from the exhibition gallery for the duration of the intervention except for when she asked about a preferred coffee choice). The seven consecutive iterations happened in quick succession as the writing unfolded. There was little editing aside from an odd capital letter here, a change of spelling there (or not). The text is laid out on these pages using the same paragraph returns that were used on the iPhone. This means that any long line of text without a return runs widthways across the A4 page as opposed to appearing in a block down the screen when constrained by the $5 \mathrm{~mm}$ format imposed by the iPhone screen (or for that matter, the A4 page of this PDF). Limitations and constraints are essential to this writing/responding exercise, to the process as writing experience.

Aside: Below are two of the seven variations in 'The movement of the aside' by way of example (perhaps the Copley asides of grasping and disenchantment respectively): catalogue (left) and birds with love machine plus redacted TS Eliot poetry (right).
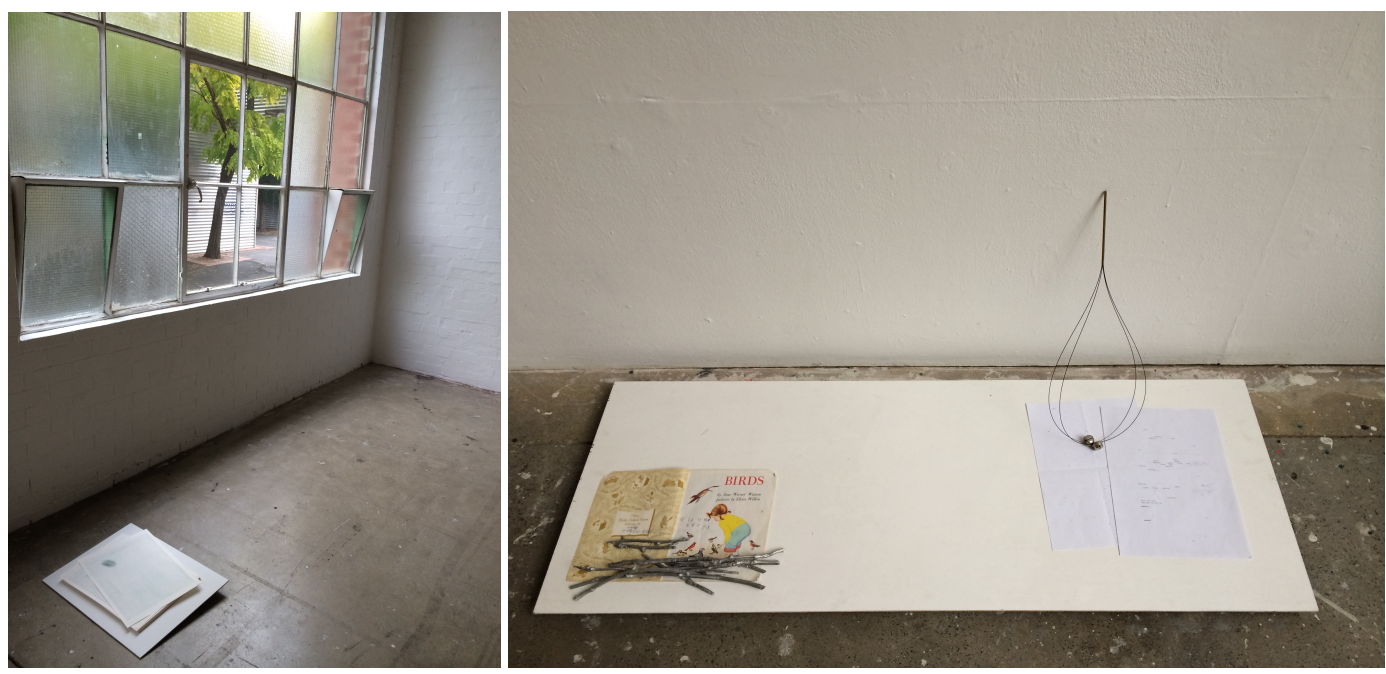

Fig. 1 (left) Martina Copley, un-folded thing 2015, colour inkjet print, ed. 100, 42 x $29.7 \mathrm{~cm}$

Fig. 2 (right) (dub) birds 2014-2015, Golden Book, cast aluminium, 20 x 33cm; Scores in a listening attitude (fire sermon) 2015, digital prints, graphite, 29.7 x $21 \mathrm{~cm}$; Lovers (instrument) 2014, brass tube, spring steel music wire, $20 \mathrm{~mm}$ round silver bells, $50 \times 21 \times 2 \mathrm{~cm}$ 
Thank you: Thanks to Martina Copley who offered up her creative work for this exercise, whose thinking and making was the stimulus to everything that has followed - now she sings. / the moon is / nearly new.

Thanks too to the two double-blind reviewers who are intrinsically part of this parsing exercise due to this creative work being published here as creative work for ERA purposes, in the Special Issue of Creative Writing as Research IV. As a result of their useful critiques, that challenged and enhanced this work in the best possible conversation, it furthers the dialogic nature of the exchange (academic with doubleblind reviewers) about a dialogue (writer with artist) about dialogue-as-dialogue (the aside as a way to discuss the movement of making). Review 1 offered the term 'making academic written art' (see above), which has now been incorporated into this discussion - thank you. Review 1 also notes:

It traces a really interesting situation - the thoughts that go through the mind of one tasked with examining and responding to the creative work of another. This is a wonderful account of that process. The critic is licensed to examine, but who is examining the critic?

Indeed.

\section{Notes to M 1}

In general terms - a large aside a toggle list (a nonfiction unconvention it could be said)

\section{Listening to silence now}

This this unconvention

On the edge of the works

Noticing inkspots mumbles from next door - the next door the door next scrape of chair sound of concrete crash of voice outside inside heads laughter snigger too like a flocks of birds a rush of wings

Just because you look at something doesnt mean youve seen it - but who said that? what page number

I support murder racism and the ruling class. The fire hydrant aside - because

our appear

acter stamped

labour; because

ducers the 
abour is

relation exist

eros $2 \mathrm{kc}$ greg

juke 89

1. pull out saftey pin

2. aim at fire - squeeze handles

raticool australia made

you bite an apple in half

i can't get up off this chair

\section{Notes to M 2}

\section{I know}

What do I know?

Socratic dialogue between

me and me leaving a paper trail leaving space where i once was leaving detritus from the catalogue not a catalogue

Do you know I was there?

How do you know i was there?

This floor needs sweeping

different

through which unknown

broken flow, skips

of editing

precedes theory

closeups

long aways 
why do teachers have low voices?

but also some

poem

Truly i'm not doing anything

Breathing twitching being

Eating apple flesh

Feet firmly on the floor

Back straight

Wishing you knew what I was asiding to, the dance of leaves, no nonsense, corrall (sp?) of pips

\section{Notes to M 3}

WD WD WD WD WDWD WD WD WD WD WD WD WDWD WD WD

skip to desired time

skip skip skip skip skip skip skip

to to to to to to to to to to to to to

desired desired desired desired

time time time time time time time

I I I I I I I I I I I I I I I I I I I I I I I I I I I I

with with with with with with with

of of of of of of of of of of of of of

line stands for line stands for

from one sound from one sound

line stands for

from one sound 
line stands for

from one sound

line stands for

from one sound

I look

I air

\section{Notes to M 4}

Uhm

nothing here

she's gone

here - is that a demonstrative pronoun? what is a demonstrable pronoun?

into print

trace an

for the mistakes

the temple bone to

[blank]

rehearsal room

spacing and punctuation

inner $\mathrm{A}$

voices 1 and 2

(Oh this if fun. I've just realised that she'll be able to follow me around because of my droppings. I think I've left enough clues. If she steps Holly Go Lightly.)

\section{Notes to M 5}

Shelves not in yet obviously

Always to the right of the body

Of course, she's right handed 
it really matters

culture facsimiles transcripts

in the question, is the

but the boy

I ask, now

offhand [round the corner]

End of the Story 87

enchantment

[she sees a black circle]

[now speaking third person]

[she sees a white circle]

[shes really looking now]

[shes not looking up anymore]

[shes not listening]

[shes taken by taken by taken by]

\section{Notes to M 6}

under The Circuit World 
It's like that

It's lime that

[end chant]

now she sings.

the moon is.

nearly new.

she weeps.

Approach Song Series

I remember the

I remember the

I remember the

I remember the

I remember the

day

time

occasion H said

Don't forget to look up.

Don't forget to up look.

Don't forget up look to.

Assembly area

Emergency

EMERGENCY [spelt out in red]

\section{Notes to $\mathrm{M} 7$}

Cappaccino please

No sugar

on the page

OR SEVEN (S), still 
mentalist

shadow

wind gust across room

wind gust inside

estimated estimate

choshi $=$

netori $=$

If the choshi is played after the netori. If I knew what these words meant. If I had a dictionary. If we had plasticine. If we could dance. Oh if we could fly. If only become winged creatures.

PS Oh that was wonderful. Thank you from the bottom of my feet, the length of my legs. Xx

(Francesca Rendle-Short, respondent/discussant for Martina Copley's confirmation doctoral research exhibition, 'The movement of the aside', Victorian College of the Arts Gallery, Tuesday 17 March 2015, 2.45-3.35pm)

\section{Endnotes}

1. Images of works in exhibition by author, taken with permission and thanks

\section{Works cited}

Blythe, Richard 2011 'Thinking about architecture: thinking about architects', in Leon van Schaik with Anna Johnson (eds) The pink book: by practice, by invitation: Design Practice Research in Architecture and Design at RMIT, 1986-2011, 2nd ed, Melbourne: sixpointsixone, 36-37

Carter, Paul 2004 Material thinking, Melbourne: Melbourne University Press

Roberts, Jennifer 2013 'The power of patience', Harvard Magazine, November-December, at http://harvardmagazine.com/2013/11/the-power-of-patience (accessed 19 March 2015)

Sellers, Susan 1994 The Hélène Cixous reader, foreword by Jacques Derrida, Oxford: Routledge 


\section{Research statement}

\section{Research background}

Underpinning this creative work is an argument that theorising out of practice has to be grounded in 'material thinking' (Carter 2004), and only through the process 'or tissue' of composition (Bolt 2006: 1) can any understanding of the world be made. Any dialogue that emerges between making and thinking - in this case new makings about the thinking (and makings) of the first makings (and thinking), as aside - is a result of the interplay of intelligences, of the artist/s at work, materials at hand, and process and interrogation of making itself. Process is crucial: immersion, contemplation and patience.

\section{Research contribution}

This work is an experiment: an account of a writing experience, a case of making academic written art. Gibson argues that etymologically to experiment and to experience are closely related and the best kind of experiments are those that are conducted through trial and error, that allow befuddlements, nervousness, that welcomes surprises, that embodies 'changefulness'. (2010: 6). As does this conjugation of asides and 'thinking in action'.

\section{Research significance}

'Parsing the aside' tests the plausibility and significance of 'examination' in responding to, or being with, creative work as well as the making of new academic work. It foregrounds process and how thinking as thinking is made in writing, highlights the benefit of immersive practice and the power of patience (as illuminated by Roberts), and makes manifest the nuts and bolts and value of dialogue and collaboration.

\section{Works cited}

Bolt, B 2006 'Materialising pedagogies', Working Papers in Art and Design 4, at https://www.herts.ac.uk/_data/assets/pdf_file/0015/12381/WPIAAD_vol4_bolt.pdf, vol 4 (accessed 4 May 2015)

Carter, P 2004 Material thinking: the theory and practice of creative research, Melbourne: Melbourne UP

Gibson, R 2010 'The known world', Brien, Burr and Webb (eds) TEXT Special Issue 8, at http://www.textjournal.com.au/speciss/issue8/Gibson.pdf (accessed 4 May 2015) 


\section{La Trobe University}

\section{Kate Ryan}

\section{The mourning dress}

\section{Biographical note:}

Kate Ryan's fiction and non-fiction have appeared in publications including New Australian Writing 2, The Sleepers Almanac, Kill Your Darlings, Australian Book Review and The Griffith Review. Her children's picture books have been published by Penguin and Lothian Books. She has a PhD in Creative Writing from La Trobe University (2013). Her awards and commendations include shortlisting for the Nancy Millis Award and a mentorship with the writer Robert Dessaix. In 2015 her short story 'Sunday Nights' was shortlisted for the Josephine Ulrick Award and she is a finalist in the Writers Prize of the Melbourne Prize for Literature.

\section{Keywords:}

Creative writing - entredeux - ambivalence - clothing 
And I must talk of tweed,

A stiff cloth with flecks like blood (Seamus Heaney)

Notice the way life begins, an inscrutable tangle (Rhyll McMaster)

If for anyone, the dress had been for him.

The day after Toby rang to tell her about Mic, Rebecca woke up thinking about a dress. She dreamt of making it from material that she hadn't thought of for at least a year. As she participated in the complicated exhausting business of getting Georgie dressed, fed and out the door, the hazy dream feeling of unravelling the material in the hall of her childhood house was still with her. She remembered wondering when the fabric would end and then a different feeling came back to her - panic about the hall getting longer and longer and the material seemingly endless.

She had known the minute she heard Toby's voice that someone had died. It was a heart attack, he said. Mic collapsed in the street. Rebecca tried, impossibly, to imagine the pain of it, a metal band pulled tight, tight, around his chest, the pavement rising up to meet his body. It was cold in London now and she thought of the Melbourne heat, of Mic's wiry arms exposed to the light, his body sprawled, wrongly angled, without dignity, as he had rarely seemed to her in life.

But the next day things still had to be done. Georgie's cereal, coat, socks, toilet, lunchbox - the list was endless - and something was always missing - one sock, a lunchbox lid, teeth still to be cleaned. But today Rebecca was relieved beyond measure that he seemed swept along, offering his toothpaste smelling cheek to be kissed and finally making no objection to Piers shutting the front door to take him to childcare. Sometimes, but not often, the torn feeling of wanting to let him go and keep him close seemed bearable.

As soon as they left she went straight into the room she used as a studio. It was tacked on to the kitchen of the flat, a kind of lean-to, but the light was good. Lately it had felt oppressive in there - the weight of her own expectations - and since Georgie was born, she was always tired. Tired and sometimes exhilarated. Tired and sometimes despairing. Tired and blank of any desire to create, so much so that at times she had wondered, distantly, whether it would ever come back.

But now that her father had died, for the first time in so long, Rebecca had the feeling that she was entering the space of her own mind.

The wall above her drawing table was covered with sketches and photos of dresses, coats and skirts - some drawn, some cut from magazines. There were nineteenth century ball gowns and kimonos and saris, cards from galleries - Braque, Dufy, Rodin, bits of old wallpaper. In a bowl on the table were pieces of broken patterned tile. Scraps and rolls of material were crammed into an open cupboard. An old fashioned dressmaker's mannequin stood in a corner. 
Rebecca climbed onto a chair and looked on top of the cupboard. For a second she thought the material wasn't there and she felt a jolt of disappointment. But then she found it - she had shoved it right to the back against the wall - and she leant over and pulled it out. She got down, brushed off the dust and spread it out on the floor, feeling its subtly roughened texture. Then she picked it up and took it to the square window so she could see it clearly in the light. The fabric was a deep blue. A pattern of diamonds in a burnt orange colour was screenprinted diagonally across the breast. She had made the screenprint herself and now she looked critically at the direction of the pattern, wondering how she could cut the material so that the diamonds were a feature but not overwhelming.

When she had imagined it at breakfast she had seen the dress clearly. Fitted, straight to the knee, a little kick pleat at the back. Like something Audrey Hepburn might have worn but with unexpected details - two semi-circular pockets above the breast of a different material, something plain, maybe grey, capped sleeves slightly scalloped with an ivory coloured button on each one. She would have to find them somewhere.

Clothes had been Rebecca's passion for a long time and this was her success: she had made it her job. She salvaged material from Oxfam, garage sales, ancient haberdashers and filled loose commissions for two or three designer shops in and around Camden where she and Piers lived.

When she first met him and he had the odd day off she had taken Piers as navigator to look for fabrics in the out-of-town op shops - although the idea of anything secondhand was completely foreign to him. The special things seemed to be at her fingertips then, as if Piers was a lucky charm. There was a pink '50s apron fabric covered in blue tea cups, rolls of dusty green raw silk hidden up the back of a draper's in Kent, a pair of ancient lawn sheets that some old lady had managed to stop yellowing. They would take a picnic or have some stodgy lunch in a country pub, leaving slightly drunk. They would sit in the car for a few minutes and Rebecca would close her eyes. He would take her index finger and make her move it around the map.

'You're very warm,' he said, 'cooler, cooler, warmer again, now you're hot.'

Then Rebecca opened her eyes and they drove whichever way it was.

Now Rebecca made dresses, shirts and skirts, both delicate and unpredictable. When no work was in the offing, making clothes felt a ridiculous activity, labour intensive and financially unviable. She knew she should be much quicker in finishing pieces and that she needed to cold call shops around Camden, Notting Hill Gate, maybe as far as Battersea, but she found the idea of this exposing and difficult.

But when things sold and Rose or Magda or Genevieve called her saying the customers loved them and she launched herself into the process of thinking and creating again it was different. It felt miraculous, the only thing in life that she could do. 
How to explain the pleasure of making things? When she found the material it began first with a feeling; perhaps it was of standing on the Hills Hoist with Toby. Burning metal on bare feet and parched grass, Toby's flecked eyes close up as he laughed, aged eight. She wanted to capture light and a moment in time. She summed this up on the labels she made - 'Hills Hoist', 'Jepson St' - after a share house she had gone to in her late teens: rockabilly music, black coffee in chipped cups and the sun on a pergola covered with red grapevines, cigarette butts stubbed in a wineglass.

The Hills Hoist dress began with fabric from Blonski's. It was a drapers in Clapham, an ancient business where you had to knock and make appointments and then the old Polish man who owned it didn't always let you in.

Once you were in he was surprisingly magnanimous, leaving you alone to look, 'As you see, darling. I have anything you are looking for.'

And it felt that way. As the old man shuffled out the back, the excitement seemed to spread through Rebecca's whole being when she saw the rolls and rolls of dusty fabric stretching far up to the ceiling. The Hills Hoist material was among the third layer she looked through - blue-sky cotton with small, squarish splodges of sun yellow. That day she had also came away with 'Domenica at Chapel'. Its name didn't come until later but she fell in love with the grey checked cotton-linen blend - an interesting mix of purple and red with a faint blue stripe. She thought it was probably from the 1950s.

Then, examining it closely later, she remembered the feeling of lining up for chapel with thirty other girls in Year 8, the green of the poplar trees in the driveway, the stained glass of the chapel. Alone in her room, sewing, night coming down, she could almost smell the Norsca deodorant that Domenica, her short lived best friend, had begun to wear, the scrum of girls pushed up close together, talking and laughing and complaining - sweat and shampoo, hair mousse, wool wash and strawberry lip gloss.

And so the dress had begun with the checked fabric and finished with small clear buttons, as that was what they were, though always straining to escape, buttoned up.

Though the seed was sewn much earlier, it had really begun to grow when she was fifteen. That was when Rebecca had stopped looking at her father's art books, the images of Raphael and Delacroix and Ingres and saved up all her money for the fashion magazines, sometimes stealing them if he had forgotten to toss ten bucks her way. English, French and Italian Vogue, Harpers Bazaar, as many as she could get hold of. She lay on the carpet of her room, the sun warming her back, and she drank them up. The long pure limbs of the models, the out-of-focus smudged eyes. But most of all the fabrics, the zips and buttons and patterns, the line of a coat and the zigzag stitching around a collar.

She spent a lot of time on the floor of her room drawing. On the backs of envelopes, in exercise books, in one of the sketchbooks her father bought her or which she sometimes stuck up her jumper and walked out with from the newsagent. She looked with contempt at the clothes of her teachers and imagined how she would rearrange 
them. She drew dresses and jackets and coats, patterned silk in the lining, covered buttons on the outside.

She went to the library and read about the fashion designers. One of her favourites was Japanese, a man whose family members had been killed, some quickly, some painfully slowly, when the bomb fell in Hiroshima. As a child, this man wrote, he was fascinated by the beauty of a bridge near the centre of his town. He walked over it twice a day to and from school, and years later the memory of the form of its curving steel over the swirling changing water came to obsess him. Rebecca was transfixed when she read that he tried to incorporate the symmetry of the bridge into the design of a dress, the water into the dull glitter of its raw silk. She imagined doing things like that too; recreating the patterns on the surface of leaves and bark, the dots on a ladybird's back and the way hailstones collected on the windscreens of cars after a storm. She wondered about making a dress in the technicolour pattern that happened when you pressed your fingers against your closed eyes.

Her aunt Cath had bought her a sewing machine for her fifteenth birthday and taught Rebecca how to make a simple dress, a skirt, to alter things.

Cath said of her old stuff, 'Take what you want, darl. Not my scene any more and some of them could be on the snug side.' She rolled her eyes. 'Slightly.'

When her mother Sarah was out at night teaching her migrant English class, Rebecca sometimes pilfered her prim little cocktail dresses. Suit jackets and skirts were mined for buttons, hems were raised, sleeves removed, pants taken in. Rebecca felt guilty but excused herself in knowing that her mother never wore these things any more, and Sarah never mentioned their loss. Rebecca felt herself intoxicated again by the smell and feel of rows of her mother's dresses, just as when she and Toby had hidden in the wardrobe as small children. Pink linen, green silk, crunchy satin and layers of soft jersey. She must have worn them once. Rebecca remembered holding up the dresses while her mother sat slowly up in bed. It must have been in the period just after Mic went. The time that had felt, to Rebecca, something like a death.

'Why don't you wear this one?' Perhaps it was an amazing clingy dress in a geometric pattern, a cool blue sheath. She held up another and another. 'This one? This one?'

'I don't know darling. I think it's a bit dressed up for today.'

The hollowed out patience she'd had, but in Mic's absence the vacancy, the sadness. A black beaded top was produced, a maroon shift with lace and white buttons.

'Not today,' she'd said. 'I'll wear it another day.'

With her friends Caro and Elyssa, Rebecca scoured op shops and came home with mohair cardigans and old lady floral dresses, battered leather belts and pencil skirts, old men's shirts. They talked endlessly about the three or four boys who lived near them who had an interesting air. These boys were different, they were sure, from the loads of football-playing, flannel shirt-wearing ones they claimed to hate. Not that they had had the courage to speak to any of them. In the womb-like warmth of Caro's 
shag carpeted room they took turns trying on their riches. Lying on Caro's bed, collapsing onto the floor at the sight of ridiculous combinations or bad fits, narrowing their eyes at the magic of the right ones. Doing up zips and buttons to cover Rebecca and Elyssa's skinny adolescent bodies, Caro's curves that were just a little too round. The glide or shove of material over thighs, the covering of scrappy grey bras. It was always Elyssa who summed an outfit up.

'That's gorgeous,' she'd say or 'No way!'

Sometimes Rebecca saw her looking at her in a particular way, her hooded eyes half closed over. Caro was oblivious but Rebecca knew that she got the clothes right most often and that Elyssa didn't like it.

Elyssa came from a big family; big and respected and always the same. Her dad was an accountant, and she had three annoying little brothers who always seemed to be breaking windows with their footballs or breaking bones by falling out of trees. It was chaos, so Elyssa said, though it seemed perfect to Rebecca. A huge immaculate house with faun couches, a manicured lawn out the back, a swing set and a cricket pitch. Elyssa's mum had frosted blonde hair and pink lipstick and she produced two different kinds of slice for afternoon tea.

'They're so bloody Catholic,' Elyssa loved to mutter. 'God, I hope she doesn't produce another one.'

Rebecca secretly liked Elyssa's mother and even the little brothers seemed bearable. Toby was a pain too, but also good to have around. At least, she couldn't imagine him not being there.

Caro's family seemed more like her own - a bit wrong, a bit damaged - something like a bruise just fading. Damaged in ways that at the Catholic school they went to, families were not supposed to be. Caro's dad had left a few years back and now, increasingly resistant, she spent her time shunted between his place - where her stepmother now had a doted-on baby girl - and her mother's. Caro's mother's sole purpose was now to confide her rage.

This was barely talked about, just as Rebecca didn't discuss the yawning space where her father used to be. Instead they gleaned new bands every week from the student radio stations that felt like the keys to an infinitely more exciting world. They speculated about Morrissey and sighed about Blondie. They swigged stolen wine and blew cigarette smoke out Caro's window, swung on swings in the dusk and bought the odd precious single by The Specials, the Jam. They played them as loud as Caro's tiny speakers could cope with and hoped that Robert Forster or Ian Curtis would come magically knocking on their door.

Rebecca loved the music but she loved the clothes more. She could see an outfit in her mind like a painting. Sometimes she drifted off to sleep thinking of Deborah Harry's wardrobe and Morrissey's shirts. When she saw a stylish university student wearing a cropped polka dot top, straight black pants and a scarf in her hair, she carried the image in her mind. She filled notebook after notebook with sketches. The clothes intermingled with the world too, the blaze of a flowering gum led to a red shirt, the 
cross-hatched wings of a dead moth, powdery and venous, conjured a dress, a dented tin can with the label half off lying on patchy grass was a puzzle that she tried to work out in visual, sartorial form.

She followed small private passions. She drew rocks and clouds for a while, birds in flight, angels from old paintings, bodies of water. She searched for greenery growing in crumbling brick walls or industrial sites. Once she took a bus to a desolate outer suburb and drew a peppercorn tree surviving in the middle of a tip and a huge silvery gum on the edge of a car yard. On the bus heading home, Rebecca looked out the window and down at her sketchbook and she thought, This is it. This is who I am.

Now, she was thirty-three, an adult with her own child, and more than anything, she wanted the dress to make a difference, to help her get to her father's funeral. She could be someone perhaps, her father's daughter after all.

But when Rebecca started to cut it was as if the idea of the dream dress were fading. She thought of the church, the mourners. Who would they even be? The regular customers she had known at her father's city restaurant would be old now, the sassy waitresses blurring into middle age. She thought of her favourite person, Mary, who prepped in the kitchen and had been there forever. She remembered her tired eyes and her patience, teaching Rebecca the right way to chop vegetables, her muted praise that actually meant something. She would be an old lady now. Then there was Monty the headwaiter, his quips, his distinguished silver hair that reminded Rebecca as a child of a king's.

Now the scissors felt heavy in her hands and she realised she was shaking. She stopped and looked at the fabric. For the first time she wondered whether the screenprint was clumsy. Would she cringe at having made it, let alone worn it? Was the colour of the material over-the top and the style too demure, none of it ironic? She looked at the clock - 11.30 - and she had to get Georgie by four. That meant leaving at 3.30. She thought of ringing Piers to see if he could do it - sometimes he left early on a Wednesday if there were no patients - but then she dismissed it. She didn't want to stop and make the call. If she stopped she might not be able to start again.

By two o'clock she had begun unpicking the material and, with an increasing sense of panic, she stopped and got up from the table. She pulled out books and magazines from the bookcase and flicked through them. For an hour or so she sat on the floor and bookmarked different pages - veering off in drastically different directions - a shirtdress in paisley material, a fifties-ish dress with orange buttons down the front. Her throat was dry and she felt jittery with hunger and thirst. She went back to her table and looked at the fabric. It was wrong. The fabric and the design were mismatched. She couldn't make it work.

She rubbed viciously at her eyes and stepped across the books, magazines and bits of material that covered the floor. She went into the kitchen, grabbed her keys and left to get Georgie.

Rebecca was so glad to see him, scooping him up, feeling the warm weight of his 
chest against hers. Glad he was him and not all the other hopeful faces. She took him home and was happy to let him fill up the rest of the day with his hugs and tears and unreasonableness, his requests for food, the making and clearing up of his dinner.

When Piers came home she was lying on the couch reading with Georgie. The flat was warm and bright. A blue glass vase with one dying orchid was on the table, petals scattered underneath, books, a toy fire engine and a couple of crayons. Newspapers were spread where Georgie had demolished a pile.

'Dadda!'

Georgie wriggled out of Rebecca's arms and ran to hug him.

Piers smiled and opened his arms,

'Hi, George Porge. How are you?'

He dropped some papers onto the table with one hand while holding Georgie with the other arm.

'Did you book tickets today? British Airways's got a special.'

Rebecca thought of the dress. She couldn't quite give up on it. It was like a puzzle that she had to work out. It seemed more important than anything else.

'I dunno. I've got too much work on and you're so busy. It would be a nightmare taking Georgie on the flight.'

Piers put Georgie down and leant in to kiss her.

'What? Don't take him then. Go on your own. It's important, surely?'

'It's so expensive and Mic's gone. What difference will it make?'

'What? It's your father's funeral. And since when have you been worried about money anyway?'

'I don't know. It's such a long way.'

Piers' prodding, as always, made her feel irritated but also clearer, even though she hadn't made a decision. She got up from the couch and walked over to the kitchen, took a glass out of a cupboard and turned on the tap. At these times she wanted Piers to tell her what to do but then she didn't want to do what he said. She tried to take in the meaning of it, the fact that Mic was dead. What did it mean when only she knew things about him and now he was gone? She had told Piers bits and pieces over the years but never the whole story. He knew about her father's affairs - the philanderer they sometimes disparagingly called him. And the rest of it, why did it even matter? Except that Mic had made Rebecca collude with it and she had known even as a child that she needed to protect her mother. And then Rebecca and Toby had been left with a depressed Sarah, barely able to care for herself, let alone them.

It was a strange thing, and unfair, but now she felt angry with Piers for the fact that he didn't know the complication of it all.

Since she had lived in London, Rebecca and Mic had had a sporadic correspondence 
but he had never come to see her despite his sweeping offers.

'We'll go the Uffizi together, the Prado, just you and me - hire a car and drive across Spain and Portugal.'

Over the years Rebecca had batted these missives back to him, enthusiastic but not specific about dates, reassured by the fact that he would not come. And now he was gone.

'I'll think about it,' she said. 'Talk to Toby again. But it would be such a rush. I'd have to leave straight away.'

'He was your father. You should go.'

'Ok, I'll think about it.'

Rebecca walked back over to the couch and picked up a picture book from the floor.

'Come on munchkin,' she said to Georgie. 'I'll read you one more and then it's bedtime.'

The next morning Rebecca stood at the sink drying a lunchbox. Sometimes she enjoyed this process. The small sandwich, the bits of carrot and cucumber, fruit. Georgie's going off to childcare still felt novel. A mother preparing a child's lunchbox - she often felt as if she were impersonating someone. Domesticity had not been the model her parents had provided. There had been a long period when the house had been a dusty empty shell, from where Rebecca and Toby had come and gone like small feral boarders.

Rebecca had been responsible for a while for the cans of tomato soup, the packets of biscuits and cheese bought from the milkbar at twice the proper price. Mic still had a key and he drifted in and out of the house every so often with food from the restaurant. Rebecca and Toby had a feast for a few days: crusty white rolls smothered with jam for breakfast, little Italian biscuits in their lunchboxes, and minestrone for dinner followed by zuppa inglese. Sometimes they skipped the main course and went straight to dessert; two custardy donuts and a scoop of the gelato Mic had managed to transport over in metal dishes, all thrown down with a little bottle of aranciato, which opened with a beautiful click. Mic didn't hang around to eat or drink, and if Sarah was around he was in and out of the house in a minute.

For Rebecca when he went it was as if the air changed temperature or music was turned off; everything seemed to close in.

Today she had hardly slept and the lunch box just felt banal.

Without turning around she said, 'Can you take Georgie today?'

'I can't,' Piers said.

He looked up from the kitchen table where he was reading the newspaper and drinking coffee. Georgie was under the table playing with his shoelaces.

'I've got a patient at eight-thirty.' 
'You still could. It's only seven-thirty. Please, I really need the time.'

'I can't. Max's late in and I've got back-to-back patients till twelve.'

Rebecca yanked a drawer open and pulled out a tea towel.

'Why not? Why does your work always have to take priority?'

Piers stood up. He looked at her blankly.

'What? That's got nothing to do with it. I've got a patient. We worked this out. I've got to go.' He bent down and ruffled Georgie's hair. 'See you later, alligator.'

'Bye, Dadda.'

'I'll be back by six-thirty. And think about the flight.'

Rebecca said nothing, just turned her face up to let Piers kiss her.

He put his arms around her and said, 'Look after yourself.'

She smelt him, fine wool suit and coffee. Suddenly she felt like crying.

Now she thought, now, I should tell him some things now. She rubbed her eyes and stepped away from him. Somehow it was never the time.

After Piers left, Georgie climbed onto Rebecca's knee and she sat holding him. She felt the comfort of him, the refuge, but also that she had to let him go. He was still in his pyjamas. Still hadn't had breakfast. It seemed too hard to do all the things she needed to do. Eventually she forced herself to get moving - coffee, toast, milk, clothes, Georgie's coat, the last minute grabbing of some vital toy. A breath when she shut the door. Getting out was the hardest part.

After she had dropped him off, Rebecca walked back towards home thinking of the work she had to do. Two skirts, a couple of dresses. She needed the extra time. For what? Not that Piers would ever say it, but maybe she should get a real job.

Instead of going home she kept walking. Past all the familiar streets with their stylish corner cafés, the sun reflecting off their windows, their pots of geraniums, the last of their smart office workers, architects and graphic designers pulling their coats around themselves as they left. After a time the terraces became closer together, scruffier and more decrepit. There were grey lace curtains in the windows and bins up-ended in the streets.

On and on she went, past the housing estate, all around her the windows stretching up to the sky, higher and higher. Past a deserted playground of peeling primary colours, a nappy unfurled on the grass. There was no one around except a few teenage boys with their tiny mobiles, smoking, throwing a swing over and over until it was entangled at the top. Rebecca was conscious of her pale face, her legs in their smooth tights, her skirt made to fit well, just as she had wanted it to. Everything felt wrong. The boys laughed at something, nothing, and looked in her direction.

She saw a small shop; rubbish was scattered in the gutter in front of it and a man in a skull cap was choosing vegetables from the stand outside. She thought of buying 
groceries. It gave her a reason for being there. She stood looking at the garlic, the yams and the piles of white onions. The colours and textures were carefully arranged, but Rebecca stared at them, finding it hard to focus. Her breath seemed to be coming too quickly. Close up she realised the smell was almost rank; the vegetables were half rotting. But still she forced herself to consider a pile of blackening zucchinis and overripe tomatoes. The smell was all around her, on top of her, but she felt impelled to buy something. She found a plastic bag and fumbled to open it, her neck and face reddening. Placing each tomato in the bag, she made her way into the shop to pay.

Inside Rebecca felt her face go hot - there were eyes and guts and yellowing flesh - a cabinet of yellow chicken carcasses and red-brown meat. Three men stood smiling and joking in Arabic. At the counter a man in a turban smoked a cigarette. Rebecca felt as if she had forgotten what to do. She looked at the man's gold-toothed smile, the deep wrinkles around his eyes.

'Can I help you, love?'

Rebecca awkwardly picked the coins out of her wallet, feeling her shallow breaths as the man waited for her. She handed over the money, wondering what he saw when he looked into her eyes, left the shop. She walked a hundred metres, past one bin, reached another, looked behind her and dumped the bag of vegetables into it, her fingers finally releasing it like something sticky.

Rebecca and Toby's grandparents were Italian - arriving in Australia when Mic was a baby, their only blessed boy, Michelangelo, a name to aspire to, fight against.

The shop they set up had Roma tomatoes, ruby-red, almost too ripe. Arturo told her that they had the things that people wanted too, sultana grapes and pears, iceberg lettuces and Granny Smiths, 'But the ones we had were the best,' Arturo said in his endless golden tales, the ones that made Mic sigh and move away. Rebecca imagined a teenaged Mic lounging in the shop on Saturday afternoons, almost bored enough to spit at the fussy polite old ladies. But still, she thought, the smell and taste of everything must have been part of him - earth on the roots of the lettuces, warm peaches and oranges lined up in perfect rows in the wooden crates.

Arturo had a smile for everyone and Mic hated it.

'How are you, Mrs Malone? We got some beautiful plums todaaay,' Mic sometimes mimicked in a gross parody of an Italian accent.

Toby always laughed but Rebecca hated it.

Mic had other things to say. Arturo's chirpy front had been far from the silence of their evenings after the shop had closed. Arturo asleep or most likely drunk on the couch at $8 \mathrm{pm}$ after his $4.30 \mathrm{am}$ start at the market. And it was all for Mic. This was the subject of many of the conversations Rebecca and Toby overheard at their grandparents' comfortable brick veneer, with Mic eye-rolling and glancing at his watch. 
When she was eleven Rebecca was sometimes given the job of pulling the cooling white plates out of the huge dishwasher and stacking them. She knew the dining room so well that from the kitchen she could imagine it without even seeing. Sometimes she delayed going in. In her mind's eye she saw the glasses glinting on the tables, the red, green and purple bottles with their brown, black and white labels lining the bar, the white tablecloths faintly creased where they had been folded, the candles waiting to be lit. Rebecca thought of it like a stage before the curtains were opened.

But often, with her father, later, after she had seen the beauty of the dining room, and she pushed back through the swinging doors into the kitchen, she knew things had changed. Once she saw Stephanie, a new girl, with her back at the sink scrubbing the huge pasta saucepans, heard her furtive sniffs. There was a hush in the kitchen too, deeper, below the clattering plates.

'We're going,' Mic said to Rebecca.

He turned to Monty.

'She's not going to work out,' he said, nodding in Stephanie's direction.

Monty sighed and shifted his black polished shoes. Rebecca thought he looked old suddenly. She noticed the yellowish circles under his eyes.

'Okay,' he said. 'I'll sort it out.'

Rebecca often saw her father's effect on people, men and women, children. He could turn his charm on randomly, perhaps on a pretty waitress, her friends, her teacher Miss Antony who they ran into down the shops one day. She had two deep lines in her cheeks like a wooden mask and looked flustered when Mic held her arm for a second or two as they said goodbye.

'It's so good to meet you finally,' he said, as if he had been waiting all his life to meet this grim middle-aged woman.

From then on she was just that bit nicer to Rebecca, as if she had markedly improved by association. Even Mic's mechanic got just the right degree of matey sympathy and did everything he could to get the cheapest parts.

She knew when to leave him alone too.

She had seen him turn viciously on a chef and a drunken customer, reduce a waitress to tears over a dropped glass. His voice was low and relentless.

'We can't have that sort of thing happening here, Janet.'

He said the name as if it had something to do with the incompetence, as if it was the most contemptible thing about this girl.

'If it happens again I'm afraid you'll have to find somewhere more suited to your talents.'

Toby often pestered Mic at the wrong time, but Rebecca knew when he wanted company. She could be his little mascot, his helper, his entertainer. He looked at her 
drawings and admired them. He swept her up and took her to galleries or plays, a film, came home with some extravagant dress for her and some smaller, less interesting thing for Toby, perhaps a toy car when he had given up playing with them or a book on insects when his passion was space. They didn't talk about the difference between these gifts but they both knew. It was different between Rebecca and Mic; there was something between them that Toby would never have.

Her dad. She never even called him that. It was always Mic. Somehow they had absorbed early that he wouldn't like Dad; its gravity, implying offices, boring suits. He was a different kind of man, any kid could tell that. They asked about him like you would ask about a good-looking older brother.

'Does your dad bring home food from the restaurant?'

'Hey, my mum and dad went to your dad's restaurant the other night.'

Having a dad who ran a restaurant was definitely better than your dad being a doctor and even better than being a builder like Emma Ainsley's dad who built most of Shopping Town. It was like having green eyes or being small - people looked at you in a different way, even if they didn't want to be your friend.

That night Rebecca said to Piers that she was still thinking about the funeral - but actually she lay awake for another night going through her excuses, only let herself sleep when she had worked out a way to avoid it. The impossibility of taking Georgie on the plane; a sudden urgent job; Piers' work. Then in a garbled conversation with Toby the next day, Rebecca finally just said she couldn't. The long distance left a pause before Toby's reply and Rebecca felt sick.

'Why not?' he said.

'I'm sorry. I just can't. It's too rushed and too far.'

'But what about me and Nonno, what about being there for us?'

Silvia had died a few years back, leaving their grandfather bereft, though they had bickered their way through most of their married lives.

'I'm sorry,' Rebecca said again. 'Of course I want to support you but it's just too difficult to get there so quickly.'

'We could delay the funeral.'

'Then Nonno will get upset. There's no point. I'll ring him. Explain. I'll find a poem and you can read it for me.'

She was wondering what poem could possibly sum up her feelings about Mic and then Toby made excuses and got off the phone quickly, sounding wounded, and Rebecca felt a mixture of guilt and relief. It was like being let off something, allowed to stay home from school when you weren't actually sick. She didn't have to go.

Rebecca's room became her sanctuary after Mic went. Toby knew he had to knock, 
her mother rarely came in and her father's circuit was generally driveway, kitchen and hall only. Sometimes she let Toby see her secret things. Under her bed were her tins and various shoeboxes - in one was their code book, a broken watch of their father's with scraps of old stripy band, her jacks, her marbles, her ribbons and buttons, her pencils and postcards, the pictures that she had cut from her father's art magazines and stuck in a scrapbook.

She had even cut some pictures from the glossy art books that he hadn't got around to taking to his new place. She had been working through - a sculpture here, a painting there. She was a bit scared of being caught but not enough to stop. Mostly it gave her a thrill, a pleasure deep inside. The meticulous cutting, the careful application of glue and the gentle pressing of each picture into her book.

All these things she showed Toby. His brown eyes shone with eagerness. His big sister. Becky, Becky, Becky.

One yawning Sunday afternoon a month or so after he left, when Toby was at a friend's house, Mic picked up Rebecca to take her out in his new car. It was green and the windows moved up and down with the press of a button. She sat in the front, her hair blowing back in the summer breeze and with her eyes half closed the green of the trees was like her most beautiful pencil.

'How about a game of pool?' her father said.

Rebecca nodded. She was so happy to be with him; he could take her anywhere.

Her father's friend Stan was at the pub.

'Stan the Man!' Mic said, 'fancy meeting you here.'

Stan had golden skin and a bright red t-shirt and when he smiled white lines appeared at the corner of his eyes. Rebecca wished he wasn't there.

Soon the coloured balls clattered on the green table and lemonade tickled Rebecca's nose as she waited for her turn to shoot.

A red-faced barman wearing a cowboy shirt wiped down the bench and said, 'Same again, gents?'

Mic and Stan drank beer, leaned against the bar and let Rebecca win a couple of times. Mic lined up the ball exaggeratedly slow and then nearly hit it off the cushion onto the floor.

'Jees-us,' he said, drawing out the word and grinning at Rebecca, 'what happened there?'

Rebecca took the coins her father had given her and played table soccer. She swung the little blue and red figures for two people, dashing around the table to be her own opponent, enjoying the clash of metal and the sinking of the little white balls. Mic looked over and laughed and Rebecca smiled. It was a tiring business though and five minutes later she sat down at a table with her Derwents and started drawing. She barely bothered with faces, only dresses. Fancy ones with sashes and wing shaped 
sleeves, long patterned skirts and lots of diamond buttons. Layered skirts in checkerboard patterns. She held the pencil close to the page and imagined how each colour would look against the next.

In an hour, even that, her favourite thing to do, became boring. Mic's cigarette smoke seemed to saturate her nose and she laid her head on the table. She turned her head sideways and tried to allow each of her chips to sit in her mouth before crunching them. The sensation of crunching chip in her ear seemed interesting for a minute. Finally she allowed the endless clatter of the cues and balls to drown her. She felt she would die if she had to stay a moment longer and, putting her head down on the table again, she closed her eyes.

She opened them when there was a tap on her shoulder. She sat up, immediately alert to her father, but it was the barman bringing her a Coke and a stack of magazines. The room was empty except for him. He winked at her and went back to his position behind the bar watching the small black and white TV up high on one wall. Blizzards had hit the midwest of America and the conditions were so bad that children at certain schools were having to stay overnight. Their parents could not pick them up. The governor was shown, square jawed and grey haired, an accent with a slight Southern lilt.

'Every day you trust your children with their teachers. We are asking you to extend that trust, to believe in their integrity.'

'Shit,' the barman said.

Rebecca stretched and opened a magazine. Mic and Stan had disappeared but it had happened before and she was deliberately nonchalant about this; she was ten, old enough to look after herself. She thought of snow and ice and children bundled up against the blizzard and she shivered deliciously. She yawned and opened TV Week and had a happy half-hour reading about soapie seductions and pregnancies, made the best of Tracks, when the urgency of her full bladder forced her to get up.

Rebecca walked out into the courtyard and the light hit her right in the eyes. Her limbs felt heavy, not unpleasantly, and she had the sense that a long time had passed. The courtyard was paved with bricks and one wall was a mass of bougainvillea. There were three or four tables with umbrellas advertising VB. She squinted around, hearing Mic's voice and turning towards it but when her eyes settled she couldn't work out what she saw. There was her father's familiar shirt but then something else, another shape. Rebecca stood very still, looking. She realised it was Stan's arms around her father, Stan's body being pushed back into a bench, his arms sliding around her father's back, Mic's close cropped dark head and Stan's with its light floppy fringe, darting and pushing and melding into one.

Toby rang once more.

'Look,' he said, 'I know it's a long way and all that but I really want you to come. We need to mark it somehow. And it'll be good.' 
'Closure', he said in an American accent, laughing awkwardly. 'And anyway I want to see you.'

Rebecca's eyes filled with tears and she cleared her throat. She stared at the print on the wall - just a few lines here and there, the shape of a breast, an eye. She tried to work out whether she even liked it. The silence went on and on.

'I'd love to see you too but I just can't. I couldn't face all those people. You know what he was like - the big man. I'd feel like a hypocrite. We've barely had contact for fifteen years.'

'You always do exactly what you want. You're over there and I have to deal with it all.'

Rebecca sucked her breath in to avoid biting back. She knew she had to be very controlled, the big sister, for it to work. And they both knew that she'd been there for a long time not doing what she wanted to do, making him eat his breakfast, spreading Vegemite on his sandwiches, dragging him to school when her mother couldn't and her father was gone.

'Look I'm sorry. I know it's hard for you looking after the whole thing. Do you need any money? I can send some.'

Toby snorted. 'I don't need money. I'm a partner, remember?'

This incredible fact sat between them, the evidence of change. Rebecca remembered Toby's letters coming, neat and regular on computer paper folded into four. She had been so happy, putting them into the box on her sewing table and not even telling Piers about them. Each stage registered, Toby's law course, his articles, his girlfriend, the house bought in Leichhardt. There was nothing secret or dangerous in them but still she had wanted to keep them to herself, relished them while multiplied. The letters were like hands pulling her out of quicksand.

Toby sounded flat now; Rebecca would always win.

'Look we can make it Monday, that'll give you enough time. Please see what you can do. Call me tomorrow.' It was the lawyer voice but it didn't convince. He knew she wasn't coming.

'Ok, I'll speak to you tomorrow then,' Rebecca said. Her voice was soothing but she was sad too. She remembered how much she missed him.

The next day, Georgie was at home so Rebecca couldn't do any proper work. She went into her studio and glanced at the bits of bright dress and felt a kind of disgust. When he slept - she was desperate for this - she prowled the flat, fidgeting with books and wiping benches. She stared at herself in the mirror. When Georgie woke crying, she struck the table softly and then harder and harder until her hand ached. Then she walked in and took him in her arms.

It was when Georgie was eating his afternoon tea, the detritus of lunch still around them that Rebecca suddenly thought of the most beautiful shop she knew. It was in 
Brixton, tucked away; somewhere she knew her clothes would be one day.

She quickly got Georgie organised and into the car, drove there.

Sure enough there was a dress. It was pale grey, exquisite, scattered with silvery leaves. Rebecca tried it on, flustered by Georgie going in and out through the curtain, but still she knew it was the right thing. As soon as the shop assistant handed it over, delicately wrapped and placed in its organic cotton bag, she felt complete. Though really it was crazy even contemplating it. One hundred and fifty pounds.

Piers was out with a friend at the pub that night and all the time she was getting Georgie ready for bed she was aware of the dress, feeling a surge of something like desire. After Georgie was settled at last she went straight into her studio where she had tucked the bag behind the door. Opening the bag and peeling back the layers of tissue she shook out the dress and held the gossamer fabric to her face, smelling it.

Her father had always noticed what she wore; he knew about clothes. It was one of the things they shared. 


\section{Research statement}

\section{Research background}

'The Mourning Dress' is a fictional piece distilled from a novel exploring themes of ambivalence and creativity. It takes as its starting point Hélène Cixous' concept of entredeux or 'between two' which, she argues, refers to '[e]verything that makes the course of life be interrupted'; its effect is that "we do not know how to "live" (Cixous and Calle-Gruber 1997: 9). The piece considers such a time in a character's life and explores ambivalence, a state of being caught between two intense, interlocked positions: love and hate, desire and repulsion.

\section{Research contribution}

Cixous speaks of entredeux as an individual's experience of an in-between time. She says: '[at] times we are thrown into strangeness. This being abroad at home is what I call entredeux' (Cixous and Calle-Gruber 1997: 10). 'The Mourning Dress' interrogates this idea to explore the origins and consolations of creativity in an ambivalent character. It explores the way the coverings placed on the body may be informed by familial loss and lack, but may also move away from it. As with the work of sculptor Louise Bourgeois (see, Celant 2010, Morris 2007), 'The Mourning Dress' uses metaphors circling around clothing and fabrics to explore psychological and familial fracture but also repair.

\section{Research significance}

This piece is one of several exploring the emotional resonance of clothes: a novel 'The Beginning of Things', PhD La Trobe University (2013), a novella 'The Mourning Dress' in progress, and an essay 'A Story in Clothes', Griffith Review 44 online, Cultural Solutions, 2014.

\section{Works cited}

Celant, G (ed) 2010 Louise Bourgeois: the fabric works (exhibition catalogue), Hauser \& Wirth, London

Cixous, H and M Calle-Gruber 1997 Rootprints: memory and life writing, trans E Prenowitz, Routledge, London

Morris, F (ed) 2007 Louise Bourgeois, Tate Publishing, London 


\section{University of Southern Queensland}

\section{Nike Sulway}

\section{Paper boats}

Biographical note:

Dr Nike Sulway is a writer and academic. She is the author of several novels, including Rupetta, which - in 2014 - was the first work by an Australian writer to win the James Tiptree, Jr Award. The award, founded in 1991 by Pat Murphy and Karen Joy Fowler, is an annual award for a work of 'science fiction or fantasy that expands or explores our understanding of gender'. Her new novel, Dying in the First Person, will be published through Transit Lounge in 2016. She teaches creative writing at the University of Southern Queensland.

Keywords:

Creative writing - ethics of care - prose - motherhood 
At the end of winter, Linda hired a car and drove to the town in northern India where she planned to stay for three months, perhaps longer. After that, she could go home, or move on. There was nothing pulling her forwards; nothing pulling her backwards. Only her daughter, an anchor, holding her exactly where she was.

She had travelled before; by herself and with her husband and even, once, with her husband and their daughter. A holiday in Bali during which they had hired a beachfront bungalow and spent their days reading, listening to music, eating and cycling.

Bella had been small then. Barely two years old. Her husband had cycled with her on his lap to a temple complex where a monkey had sat next to their daughter while they were eating. They had taken a photograph in which Bella's plump, sun-warmed face was creased with concern. Her empty hands, which she was holding out to her father, were shiny and sticky, with small blobs of fruit mashed between her fingers. And there was the monkey beside her, knees to its chin, its black-fingered hands neatly holding the stolen banana.

She wondered where the photograph was now; her husband must have it. It seemed only fair: she had Bella, and he had the photographs of Bella.

Perhaps it had been a mistake to come to India. People were suspicious of her in a way they had never been when she travelled alone, or with her husband. They peered at the empty space beside or behind her, where her husband must - it seemed to them - be going to appear. If they were polite they didn't ask where he was. But many of them were not polite.

Lying would have been easier than telling the truth, but she was determined to live honestly, in a way she hadn't felt able to live when she was married.

'I'm divorced,' she said.

Men and women, cabdrivers and shopkeepers and waiters, shook their heads. They opened their hands and shrugged.

'That is too bad,' they said. Or, 'I am very sorry.'

She was not an unattractive woman, and Bella was pretty, with big eyes, long eyelashes and a full, pink mouth. But after she told people she was divorced, they were not interested in getting to know either of them. They served her tea, or drove her to where she needed to go, and then turned away. This is what she'd expected, what she'd wanted, but at first it was disconcerting to be nobody, and nothing.

She had booked a room in a guesthouse, hoping for something in a state of genteel decline she could tell stories about when she eventually went home. According to the website, the building had once belonged to a maharajah. The photographs showed lotus flowers in a courtyard pond; bedrooms with heavy, carved furniture; a dining room with white tablecloths and silver cutlery.

The bell on the front counter didn't appear to be working, but shortly a woman a few years older than herself - a white American wearing a pink sari - came and showed them to their room. The woman cooed over Bella, patting her head as if she was an agreeable pet. When they reached the room the American woman - Kate - looked 
around at it disapprovingly, especially at the little bathroom, as though she had never seen it before. She told Linda what time to come down for dinner and then left, closing the door firmly behind her.

There had been no other cars in the parking area, no people lingering in the reception area. On the second floor, as they had walked along the tiled corridor, all the other doors had been closed. Linda sat Bella on the end of the bed. Somewhere, perhaps outside the door-length shutters on the opposite side of the room, she could hear a radio. Bella slid onto the floor and began taking off her shoes.

Linda opened the shutters. One of them was not properly attached to the wall at the top and the paint on the outside of the shutter was flaking away. Linda imagined herself fixing the hinge before she left, without saying anything to her hosts. A small, unobserved kindness.

A narrow, tiled verandah ran around the inside of the second floor. A little further along, a man was sitting in a chair reading a newspaper. Beside him was a portable table, on which sat a radio and a jug of water.

Some of the shuttered doors to the other rooms were open, and inside the rooms she could see unmade beds, suits or dresses on coat hangers. Through one window she could see a rumpled bed and a woman's bare legs.

She filled the basin in the bathroom with water and washed both her own and Bella's face, hands and feet. Then they went for a walk.

This would be the first of many walks, so she felt no pressure to remember everything, though she looked at it all with a sense of impending permanence. This is the shop where I will buy the paper each day, she thought. This is the beggar I will pass on my walk each afternoon. This is the tree under which I will drink tea. Sitting in one of the folding metal chairs, day after day, watching the town and its people go about their business.

She looked at each face they passed, wondering which of them would become familiar to her, which would become acquaintances. She did not imagine making friends. That is not why she'd come.

Many of the houses were behind walls, over which treetops extended. She did not know the names of the trees, but she imagined they had exotic names. In the spring or summer they would yield colourful fruits and flowers. Buddha had sat under a Bodhi tree, but she couldn't call up in her mind a picture of a Bodhi tree. Whenever she tried, the tree she imagined was a cross between an elm and a fig, with buttress roots and a shaggy, dense canopy of leaves.

Everything was just as she'd expected. Even the river, which was wide and brown, with stone steps leading down to the water. Men and women squatted there, washing their clothes. A group of boys were swinging from a rope into the water. Their long, thin legs and chests and arms glistened as they swung up towards the fading light. And then let go of the rope and arced into the water.

Surely her money would go further here than at home. She could buy a house with a walled garden. Bella would learn to speak the local dialect, and would go to school 
with the local children. Once a year, perhaps more often, they would fly back to Australia so that Bella could see her father. Or he would come here. He would stay in the guesthouse where they were staying now. In the evenings, he would come to their house for dinner. She would serve exotic meals in the walled garden, and tell amusing stories about her early days in the village.

She could set up her own practice, or join a local one. The pay might not be what it was at home, but the cost of living would be lower. She would learn about local health issues, write papers for medical journals, make a difference to the lives of the people who lived in this town, and to the rural poor, too. She could make something small but significant of herself, of her life.

Back at the guesthouse, the dining room was open. A statue of the elephant-headed goddess - on wheels - held back one of the doors. The doors were heavy, dark timber polished to a high gleam, with brass handles. They did not look like an original part of the building: there was a two-inch gap between the top of the doors and the doorframe.

There were about ten small tables in the dining room. The radio-man was there, but he didn't look up as they entered. A woman was sitting by a table at the window with another man, and Linda wondered if hers were the bare legs she'd seen stretched across the sheets in a way that had suggested her whole body was naked.

Four businessmen came in, smiling at each other, and laughing deep, confident laughs. They brought a sense of liveliness to the room, pouring water into their glasses, pulling napkins over their laps and rearranging the cutlery at their places.

Linda ushered Bella towards a table near a window, with a view of the mountains. She'd settled Bella into her seat and was just taking her own when Kate emerged from the kitchen. She'd changed into American clothes, and was wearing an apron with the guesthouse's silhouette printed on it, a little crookedly. She counted the occupied tables, then disappeared again. The doors to the kitchen were like the ones Linda remembered from the restaurant scenes in Sesame Street. They swung back and forth after someone passed through them, and had porthole windows. Kate returned with menus, and went around placing jugs of iced water on the tables where people were sitting.

When she reached Linda and Bella, she asked if they would like company for dinner.

For a moment, disorientated, Linda wondered if this was a service offered by some establishments in India. She glanced across at the woman with the bare legs, and the man opposite her. The guesthouse's website had claimed that it was a welcoming place. Friendly staff, the site had said. Family business.

'It's just we've got an older gentleman staying alone. A retired fellow. He's from your country.'

'Oh,' Linda said. 'I see.'

'He'll be down in a minute. I'll bring him over, shall I?' 
When the older man came in he was halfway across the room before he noticed Linda and Bella. He hesitated in a way that made Linda think that they were sitting at his table. Kate rushed over and led him to them.

The man's name was Michael Miller. 'But you can call me Dutchy,' he said, winking at Bella.

'Yes, Mr Miller,' she said.

Kate took their orders and hurried away. The swing doors clapped against each other. Linda wondered where the name Dutchy had come from, but she didn't ask. 'Have you been staying here long?' she said.

'Reckon so. About two years now. Better than any retirement home, I tell ya.'

He nodded towards the men in suits, who were drinking beers, their jackets hanging off the backs of their chairs, their white shirtsleeves rolled up to their elbows.

'They work for a construction company, those blokes, overseeing the building of the new shopping centre. They stay here a couple of days each week.'

Mr Miller was smaller than Linda had at first thought. His wrists were fine-boned and his fingers long and uncalloused. He poured water into all their glasses and then clinked glasses with Bella. Cheers! There was a heat-rash creeping up his throat, just inside the collar of his shirt, but otherwise his skin was healthy and only faintly lined. Like a piece of paper that has been crushed and then ironed.

Kate brought everyone their food. Linda began to wonder if she was the only member of staff. Through the swing doors, she occasionally glimpsed a cook, wearing checkered pants and a white shirt, but he was a local person. His face - despite the steam and heat of the kitchen - was serene and beautiful. His black hair was thick. Soft curls peeked out from beneath his starched white chef's hat.

After Linda's last attempt to call her husband after the divorce, she'd cycled home from the clinic where she was working. The cycle path took her along the river and under the bridge. She knew she had to pick up Bella from day-care, and buy something to cook for dinner. There was a leek, goats' cheese, and some tomatoes in the fridge, as well as half a bottle of cheap Chardonnay. She would have to get money out of the ATM before she went to the market, because the market did not have EFTPOS.

She found herself having to speak to herself about what she was doing like this. Not aloud - she wasn't crazy - but inside her head. The instructions she gave herself were in third person, and she found them difficult to follow. The middles of them kept falling away, like collapsing bridges.

When she got home, she pulled the landline out of the wall. She wanted to hear his voice, but she wanted even more for him to experience what it was like to have her not answer the phone. She took off her shoes and her shirt and opened a window. She poured herself a glass of wine and sat, for an hour, with no lights on and no music playing, with the apartment arranged around her almost exactly as it was when she 
was not there. After an hour, she looked out the window. There was the moon, and the city's skyline. Everything just as it should be. Water had pooled on the table around her wineglass. She was standing at the sink, tearing off sheets of paper towel, when she remembered that she hadn't picked up Bella.

She raced down through the building and retrieved her bicycle. She called the centre first, and then her husband. Nobody answered. She thought about calling the police, to report herself. The relief she felt at the thought of being arrested, of being gaoled, was so complete it pricked her to tears. She would not have to remind herself where to be anymore, or what to do. She would not be responsible for keeping herself, or anyone else, alive.

She didn't think about committing suicide any more. She was always careful not to notice how easy it would be to bring home what she would need from work. Instead, she focused on what would happen to her body afterwards. How it would look. How it would feel in the hands of the doctor performing the post-mortem.

The day-care centre was closed: all the lights off and the gate locked. She should have plugged the phone back into the wall and checked her messages before she left the apartment. She cycled over to her husband's house. Her thighs were starting to ping. Her husband had painted the front door. It was the same colour it had always been, but the paint was fresh. She could hear Bella laughing as she came up the path to the house. She couldn't knock. The instruction for doing so wouldn't travel through her body to her arms, her fists. She stood in front of the closed door and waited. Eventually, she reasoned, he would have to open it.

Someone would have to come, and open the goddamn door.

She woke up too early, after a restless night. Bella was sleeping diagonally across the bed. She kissed Bella's hot cheek and brushed the sweaty curls back from her forehead. She put a pink scarf over the lamp and went onto the verandah, leaving the door ajar. She needed to get some air. She felt as if she was suffocating. As if she was being sealed inside a clear plastic bag.

She'd met her husband in a health food shop. She'd thought this was a good sign, but of what she could no longer remember. She had told her therapist about their meeting in great detail, but neither of them had been able to make anything of it. It was like telling a long, detailed joke for which she didn't know the punchline.

She went downstairs and through the courtyard in bare feet. The lights were on in the kitchen. The elephant-headed goddess had been rolled across to hold one of the kitchen doors open, and a tall fan was set up, turning its silver head left and right, blowing air in through the open doorway. Kate was sitting on a kitchen bench, one knee tucked under her chin, smoking a cigarette. The man with the dark hair was preparing food. Linda thought about going in to speak with them, but she couldn't think of a reason to do so. 
The man came and stood in front of Kate, between her knees. He put a morsel of food in her mouth. After she'd swallowed, she inhaled on her cigarette and then blew a plume of smoke into his face.

It was late afternoon. Linda was lying in the shade with a book, and Bella was floating paper boats between the lotus flowers in the pond. Kate came through with a basket full of white tablecloths. She smiled when she saw them, and stopped, shifting the basket onto her hip.

'I'm going to the market after this,' she said. 'Would you like to join me?

Linda put her finger on the page, as though she really had been reading and needed to keep her place.

'The market?'

'You'll love it. And it's not far: an easy walk. No need to change.'

'Oh,' Linda said. 'Ok.'

Linda went up to her room and collected her bag, and sunhats for herself and Bella, and then all three of them set off towards the market.

The dirt road looked pretty in the late days light, almost golden. Whenever they passed beneath a tree, Linda felt the coolness of the shade move over her like a caress. People passed them on rattling old bicycles. Bella ran ahead of them, but not so far that Linda needed to worry. She was a well-behaved child: when she reached a crossing or a corner she stopped and waited for the adults to catch up.

They were nearly at the market when Linda heard a loud, crumbling noise. People had been streaming forwards, and she was moving with them, but suddenly and quite violently the tide changed. It started to flow backwards.

Linda grabbed Bella and pulled her close. It felt strange to be standing still in the middle of the backward-flowing stream. Faces kept coming towards her, and then flashing past, as though borne away on a dusty floodwater.

The crumbling sound grew louder. There was a plume of dust ahead of them, rising and puffing outwards like a genii's cloud. A building was collapsing into the street. Falling down onto its knees, then its elbows and hands.

Linda picked up Bella and passed her to Kate.

'I'm a doctor,' she said.

She kissed the back of Bella's head, and held her hand against her back, feeling the reassuring solidity of her body. She could smell blood, already, and hear the soft groaning and mewling of the wounded.

Linda shared a long look with Kate over the top of Bella's head. They understood each other. They understood what needed to be done.

'Of course,' said Kate. 'Go. I'll take care of her. She'll be fine.' 
Linda fought her way towards the heart of the disaster. One woman she passed was holding her hand to her head; blood ran through her hair onto her dusted face, but it was just a flesh wound.

The building had collapsed in such a way that it blocked the whole width of the street. There was a high pile of rubble on one side, sloping downwards into two long barrows on the other. Linda thought of the child pose she'd learned at yoga, remembering the feel of the rubber mat against her forehead and nose. Behind the ruined building there was a garden, no longer secret or shaded. A man sat on a platform under a tree - a neem tree - a newspaper open before him, a pot of tea cooling by his side.

Linda turned her attention to the street, and to the men and women whose bodies were being pulled out of the rubble.

'I'm a doctor,' she said, over and over.

She had no implements, no medicine, nothing of use, but she knew what needed to be done. She asked someone to bring clean water and soap, and cloth she could use for bandages.

The man with the newspaper finally shook himself free of whatever held him and went inside his house. A little later a woman came out with bowls of clean water, soap, sheets, bandages, and needles and cotton and scissors.

Linda got them to move the injured bodies into the shade of the garden, to lay them out in rows. She moved along the rows doing what she could. It was not long before they brought her the first dead body. Linda began washing the old woman's face and hands, but someone came and took the cloth from her, moving her along to deal with the living.

The garden grew quiet. There was an unfamiliar bird singing in the tree. Someone came running with a camera; Linda could hear the old-fashioned shutter, and then the soft, heavy click-clacking of the film being wound.

All of the bodies under her hands were thin and dark and coated in dust. She wanted to tell one of her patients, a young girl, that she would need to go to a hospital. The girl had at least three broken ribs. There could be internal injuries: secret wounds Linda could do nothing to diagnose or treat. She tried to tell the girl to lie still, to breathe as gently as possible. The girl smiled up at her, uncomprehending, and nodded.

The sun disappeared. Somebody brought a ladder, and strung a set of party lights across the gap where the wall had collapsed. Others brought torches and lanterns. Linda stood and stretched, then moved to the next patient and crouched down again. She was like a toy that could only repeat the same actions over and over again. Bending, cleaning, stretching, stitching. Narrow, urgent hands ushered her from one patient to the next, pushing at the backs of her elbows as if she was a child.

Once, as she knelt over someone, she looked up and saw the bare-legged woman standing in the garden. She was talking to the boy with the camera, gesturing angrily with her hands. 
When Linda arrived back at the guesthouse all the lights were out. She could barely manage the stairs, barely open and close the door to her room. She sat on the edge of the bed and washed her face and feet and hands with a wet washer. Someone had put a covered plate on the bedside table. She lifted it, but could not eat the cold food that lay there.

In the morning, when she woke and found that her daughter had disappeared, along with Kate and the chef, Linda tried calling her husband. She let the phone ring out, then dialled again. And again and again.

She went down to the dining room, to the table by the window where she and Bella had sat the day before. Mr Miller was there, and she asked him if he had seen Kate, or Bella. She tried not to sound hysterical.

The bare-legged woman came over, cradling a cup of tea in her hand, and asked them whether they knew where Kate was, or Kate's husband. Then, one by one, the businessmen, too, began asking where Kate and her husband had gone. Linda had to explain to each of them that her daughter, too, seemed to be missing.

At first, nobody seem overly concerned. They were more worried about who was going to make them breakfast. Who would change the sheets on their beds and bring them jugs of iced water? They asked Linda if her daughter wasn't just playing hide and seek, or sleeping in one of the empty rooms, or under the bed.

They split up, conducted a search of the premises, and then came back to the dining room. Kate's room was empty: it looked ransacked. And her car was missing. Bella's small suitcase was gone. None of them could remember when they had last seen Bella. Not even Mr Miller, who had folded paper boats for her to float on the courtyard pond.

The guests sat Linda in a chair near the window and offered her coffee. They talked about notifying the police, but nobody knew the number to call. The bare-legged woman thought perhaps they should call the American embassy in Mumbai, but Linda and her daughter weren't American. Nobody knew the number for the Australian embassy. Eventually, someone found a phone number for the police. Mr Miller left a message on their answering machine, but nobody was sure whether the person who checked the messages would understand English.

There was a lull during which nobody seemed sure what to do next. Somebody started cooking breakfast, which appeared to settle things for now. The guests were like small children whose teacher has disappeared in the middle of class, and who go on doing the things they always do on a Wednesday. Sooner or later, someone would come to tell them what had happened, and to take over the running of things, but in the meantime they followed the pattern of the day as faithfully as they could.

Linda had to do something, so she decided to walk into town. There must be someone she could report to; someone who would do something. 
She reached the place where the wall had collapsed. There was the gap, like a lost tooth, and the pile of rubble that did not, any longer, look like a stone giant collapsed into the child pose. The bodies were gone from the lawn, and the string of party lights, and all the other paraphernalia, but the man was there in his garden, with a fresh newspaper and a pot of tea.

When Linda had married her husband, it had been partly because he was so imperturbable. He was tall and solid and not particularly attractive. Married women noticed him, but young women - single women - did not. He had wanted to marry her too quickly, and she'd had to hold him back, but eventually she'd relented.

She leaned against a portion of wall that was still standing, feeling it give slightly as she did so. The bricks or stones behind her shoulders ground against each other like old teeth. She was tired, she realised. Too tired to keep going.

The neem tree extended its branches over the street. A bicycle clattered past. She felt her phone ringing in her pocket and put her hand in and held it. The phone vibrated like a small animal against her palm, something alive and urgent. 


\section{Research statement}

\section{Research background}

This work of contemporary realist fiction explores the gap between theoretical models of ethical decision-making based on gender (Gilligan 1982) and based on broader cultural contexts (Ford and Lowery 1986). The work explores the notion that ethical decision-making is multiple, embodied, emotional and inarticulate, as much as, if not more than, it is singular, intellectual and/or theoretical. The story presents a complex overlapping of responses to the problem of who to care for, and how, and demonstrates the messy humanity of characters who embrace, rather than retreat from, personal and relational crises.

\section{Research contribution}

This original work of short fiction takes an exploratory and original approach to exploring ethics of care. The narrative explores Ford and Lowery's (1986) proposal that differences in the moral reasoning applied by individuals are as much a consequence of life situations as gender. The work explores the uniquely complex or hybrid proposition that the ways in which ethics are a product of culture, and cultural difference, as well as gender.

\section{Research significance}

The work makes an original contribution by describing and illustrating the relationships between gender, ethics and culture. The work presents complex knowledge about ethical decision-making in the form of a creative, rather than theoretical, narrative. It has been published in a quality peer refereed journal of creative writing research.

\section{Works cited}

Ford, MR and Lowery, CR 1986 'Gender differences in moral reasoning: a comparison of the use of justice and care orientations', Journal of Personality and Social Psychology, 50 (4): 777-83

Gilligan, C 1982 In A Different Voice, Cambridge: Harvard UP 


\section{RMIT University}

\section{Julienne van Loon}

\section{The fifth story}

\section{Biographical note:}

Julienne van Loon is a Vice Chancellor's Senior Research Fellow in the School of Media and Communication at RMIT University. An Australian fiction writer and essayist, her publications include the novel Harmless (Fremantle Press 2013) and the short story 'Bring closer what is left to come' in Best Australian Stories (2014). Julienne's most recent scholarly articles have been published in TEXT and New Writing and her research interests include play in context of research, philosophical fiction, and the form of the essay.

Keywords:

Creative writing - contemporary fiction - Clarice Lispector - Buddhism - violence against women 
The story could be called 'The story of K'ang Ming Kan'. Another possible title would be 'The Tiger.' Or, alternatively, 'The assault.'

The first story is about K'ang Ming Kan, who was born to a wealthy family in Northeastern China during the fifth century, under the rule of the Northern Liang. Perhaps because of her family's wealth, K'ang Ming Kan was abducted at the age of sixteen. It is rumoured that she refused to give in to her captors, though who is to say what this means? The thieves took her far from her home to an isolated mountainous region of the far north-west, where she was forced to work as a shepherd. She did so for almost a decade.

I picture K'ang Ming Kan tending her livestock during those many years beyond the drama of the initial theft. Did she ever feel her body her own again? Or was she, like the livestock she tended, reminded daily of the limits of her freedom? The story goes that one day when she was working in the fields she happened across a wandering Buddhist monk. His explanation of the Buddha's teaching was the most convincing philosophy of life she had ever heard. She asked him to grant her the five precepts of a Buddhist layperson, and he did so. The next day, she made a determination: she would escape her captors. Her plan was humble. She would simply walk away.

The problem was that the young shepherdess did not know her way home. She chose to travel east, towards the rising sun. Perhaps it was autumn. Perhaps she had no shoes. She walked and begged for food and water, and then walked some more. At the base of the Mount Wutai she came to a rest beneath a juniper tree and closed her eyes. There were no longer any farms or villages in sight, only the imposing ranges rising up to the east, arid and cold. Sheer exhaustion threatened to overwhelm her. Her feet ached with blisters. Her stomach groaned for food. When she opened her eyes again she found herself looking squarely into the eyes of a wild forest tiger that lay languidly, gazing at her from beneath a nearby tree.

The animal blinked at her and licked its lips. K'ang Ming Kan lowered her gaze. "If this is the end," she thought, "then let it be so," and at the moment of acceptance her fear of the tiger lifted and disappeared. Just then, the animal stood and stretched, pushing its chest to the ground and its nose to its forelegs, as if bowing towards the beckoning east. It walked a little ahead, then paused to look back at K'ang Ming Kan. She stood up. The tiger walked on some way then paused once more. The young woman followed. In this manner, the two travelled companionably through the Mount Wutai ranges. They walked for hours, days, weeks. As they descended on the other side of the mountain, K'ang Ming Kan recognised the valley of the Yellow River and knew she was approaching her home village of Kao p'ing. When they arrived at the outskirts, she stopped. The sky was tinted with the pale orange tones of a dry season sunset. The air smelt of dust. K'ang Ming Kan straightened her clothes and smoothed her hair, preparing herself to meet her mother once more, but at that moment, there was a rush of white noise in her ears, and when she looked over her shoulder the tiger had disappeared. 
In the next moment, rough hands grabbed her from behind. Someone threw a coarse sack over her head. The air left K'ang Ming Kan's lungs and she blacked out for a time. When she became aware of her surroundings again, she realised that her wrists were tied behind her back, and she could no longer feel the tips of her fingers. She had been abducted.

Hence, the first story comes full circle. It is endless.

The next story is also about K'ang Ming Kan, and it is the same story, up to a point. In this version, there is an important intervention immediately following the second abduction. K'ang Ming Kan's second round of captors apparently keep her captive quite close to her home town, and word gets back to her family. A ransom is promptly negotiated, and after a few weeks she is released.

How then, does one settle back into normal life? By now in her mid-twenties, K'ang Ming Kan lives with her parents for several years, but there is a problem. Her ordeals mean that she is no longer marriage material. She pleads with her parents to be given permission to ordain as a Buddhist nun. They are skeptical. Buddhist ideas are new to their area and might lead to trouble with the ruling patriarch. Eventually, however, her parents agree to her request. She is granted robes. There are no monasteries for women in the region of the capital at that time. The records tell us that in 348, K'ang Ming Kan travelled south of the Yangtze River with ten other ordinate women to appeal to a minister in the Jin Dynasty for a place in which to practice. They must have made quite an impression, for the minister looked sympathetically on the request and converted one of his private residences to accommodate the women. It was here that K'ang Ming Kan would live out the rest of her days.

The third story, which now begins, is called 'The Tiger' and it begins with me. It begins with me reading about K'ang Ming Kan fifteen centuries later and becoming completely enamoured of the tiger. When she is granted the opportunity to break out of the circle, K'ang Ming Kan lives a perfectly good life. I can picture her immersed in meditation and chanting and the other daily rituals and routines of monastery life, making a project of stillness. She goes on, incidentally, to become a leading teacher in early Buddhism, which is why her story is written into the annals of history. But I can't help but wonder: during all those decades in robes, did she ever find herself longing for the close and understanding companionship of the tiger? I mean, really, didn't she long for it?

The fourth story is also about me, but it opens at a different time. The story begins, as it has often done, with an assault. I work in state-funded, inner-city primary school, a feeder to a neighbouring housing estate. It is a neighbourhood of a few tight blocks in which meth amphetamine wreaks havoc. I am on my way to school one weekday morning when I am assaulted. I should mention that the children I teach see me in the music room out of choice. We work one-to-one on the violin and the cello. They are still very young and are wonderfully attentive to the transformative capacity of music. I love teaching them. I love my job. But that morning, as I am getting out of my car, a stranger grabs me from behind. He is unkempt. The stench of him is so awful it makes me gag. The man has appeared as if from nowhere and his thick, ropy fingers have hold of the shoulder bag in which I keep my laptop. But he will not have it. I won't let 
him. When this becomes clear to him, he pulls out a weapon and stabs me in the leg. The swift force of the energy of this act shocks both of us: no sooner has the knife gone in than the stranger turns and runs away down the street, empty-handed. The precious shoulder bag, with its cargo intact, falls open on the road. It all happens so quickly that it takes me a little while to understand that the itch in my thigh is to do with wetness, that it is to do with the passage of my own blood.

The fifth story desires to be called 'Intersection.' It will be some time before I'll be ready to return to school. Like the second story, the fifth will put a stop to the endless loop. It is in this story that I am introduced to the story of K'ang Ming Kan for the first time. Did I tell you that I am still not ready to return to school? The chief problem with the fifth story is that it remains unfinished. I aim to establish a junction of sorts. That is my plan. It's just that I'm on the long walk. I am on the long walk, and I am still awaiting the appearance of the tiger. 


\section{Research statement}

\section{Research background}

'The fifth story' approaches gendered violence in a manner that foregrounds both repetition and the possibility of intervention. It engages intertextually with two sources - a biography of a $4^{\text {th }}$-century Chinese nun and a short story.

\section{Research contribution}

Structurally, this work echoes a like-titled short story by Lispector: each text begins over and again, imitating a cubist painting. Repeated attempts at beginning emphasise the way in which the matter at hand can perhaps never be properly broached or understood. Lispector's work has been noted for how it 'foregrounds perception that transcends blinkered normality' (Power 2014). This work links an early biography with a recent assault in inner Melbourne to attempt to achieve the same end. Closure is disturbingly elusive.

\section{Research significance}

This work extends a developing trajectory in Australian fiction that engages with Asia and early Buddhism, including my own earlier works (2005, 2013), and works by Chi $\mathrm{Vu}$ and Hua Pham. Such works re-interpret early Buddhist fable while privileging feminist approaches to subjectivity. This work is the product of a nationally competitive Asialink Arts residency at Peking University, Beijing, 2014. It is a timely engagement in the cycle of violence against women and, importantly, offers women who have been victims of violence the narrative possibility of courage and hope.

\section{Works cited}

Lispector, C 2013 [1986] 'The fifth story' in A Ziegler (ed) Short: An International Anthology of Five Centuries of Short-Short Prose, Poems, Brief Essays, and Other Short Prose Forms New York: Persea

Pham, H 2014 The Other Shore Sydney: Seizure

Power, C 2014 'A brief survey of the short story, part 56: Clarice Lispector' The Guardian 5 March, at http://www.theguardian.com/books/series/abriefsurveyoftheshortstory (accessed 11 May 2015)

van Loon, J 2005 'Wild dog' The Monthly May, 47-9

van Loon, J 2013 Harmless Fremantle: Fremantle P

Vu, C 2013 Anguli Ma: A Gothic Tale Artarmon: Giramondo 


\title{
Central Queensland University and independent scholar-writers
}

\author{
Regina (Ineke) Acton, Zoe Allen, Vivianne Barry, Zela Bissett, Janet Blake, \\ Donna Lee Brien, Sue Davis, Matt Eliot, Catherine Gamble, Vanessa Gregory, \\ Pam Miller, Kathie Roberts, Irene Waters, Libby Woodhouse and Lucy Yule
}

\section{At land's edge: three collaborative poems}

Biographical notes:

Regina (Ineke) Acton is an educational consultant who produces creative writing and visual art works.

Zoe Allen, has experience in human relations and event management, is studying a Bachelor of Business and works at CQUniversity, Noosa.

Vivianne Barry, Executive Producer of TEDx Noosa, works with businesses to drive operational innovation and improvement.

Zela Bissett is a writer and teacher who fosters an appreciation for the arts and arts production in young people.

Janet Blake is an author, artist and President and board member of several global nonprofit organisations, and is studying in an MBA program.

Donna Lee Brien is Professor of Creative Industries at Central Queensland University, where she leads the Creative Arts Research Group.

Dr Susan Davis is Senior Lecturer at Central Queensland University and a researcher with extensive experience as a director and writer of theatrical scripts.

Corinne Deering is a writer and an artist based in Noosa, Queensland.

Dr Matt Eliot holds a PhD in Human Centered Design and Engineering and is a senior academic at Central Queensland University.

Catherine Gamble has a Graduate Certificate of Creative Industries (Creative Practice) and exhibited a portfolio of her creative work at the CQUniversity Art Space in 2014.

Vanessa Gregory lives and works on the Sunshine Coast in Queensland.

Pamela Miller has taught for 40 years. She holds a Master of Letters in Visual Arts and Design and a Master of Education.

Kathie Roberts moved from New Zealand to Noosa two years ago, where she is developing her writing.

Irene Waters, a research higher degree candidate at Central Queensland University, has been published in the anthology Eavesdropping $(2012)$ and in Idiom $23(2013,2014)$. 
Libby Woodhouse is a senior radiographer with Breastscreen, and has creative and research interests in writing and women's health.

Lucy Yule is an emerging writer.

Keywords:

Creative writing - collaborative poetry - collaboration 


\section{At land's edge, I}

Drove international visitors to the National Park

to see the kiosk

only to be surrounded by massive goannas.

The environment

of the Noosa River mouth

is hostile -

yet people control how they interact with it.

An empty beach

fills my soul

with calm and peace and awe.

The community envelops our family,

cloaking us with welcome.

Sitting in a café

sun setting

glasses clinking

dogs running along the beach

people laughing,

and me,

not wanting to leave.

Cocooned

awake, alive

in tingling, sparking flow.

Unplugged,

elastic time,

on fire,

Surfing the edge

of magic.

Exhilarated

riding the sparking waters,

the kite

flying above.

The whirling carnival

of lorikeets overhead,

cascading blossoms of

jacarandah and hibiscus.

I open fully to the river, and

find

my home. 


\section{At land's edge, II}

We left the continental shelf

with the Nghai Tahu

in the capable hands of Captain Maru

descendant of the master navigators

of Polynesia.

They warned us we would be sick

as the great catamaran

plummeted into the open ocean

where

in the deep rich trenches

young sperm whales

fed voraciously,

building their massive bodies.

The horizon line,

unbending, steady,

dark.

Moving down the picture plane,

the turquoise green slides in,

softening the blue,

blending, fragmenting it.

The two turtles appear, tiny at first.

They are coming closer

frolicking, diving, weaving together.

A taste of freedom

then they are gone.

The horizon is still there,

straight, unbending, solid and steady.

I lift my face to the sun.

Poised at the edge,

alone at Hell's Gate.

Seems the wrong name for a place

of such beauty.

A beckoning invitation whispers.

Reach up.

Reach out.

Touch infinity.

One step closer

is all it will take.

Take flight. 


\section{At land's edge, III}

Seven months pregnant

and the search is over.

I have found home

on the edge

of Lake MacDonald.

I drove here at dawn

following some unknown urge.

Stumbled down an overgrown track.

Past a For Sale sign.

Birdsong and mist.

I know this is the place.

The expanse of white pristine sand

stretches invitingly

as far as the eye

can see.

I breathe in the salty air

and join

in the infectious joy

of my dog as

we run free.

Waves thrashing

like clothes in a washing machine.

Diving down deep

grabbing breaths.

Frolicking with him,

without a care in the world.

Now old, the dog

walks into the water

letting it lap over his abdomen

oblivious to the

rays and fish.

His mouth hangs open,

just slightly,

making him look

both like a puffer fish

and a demented friend. 
Pelicans drift aimlessly,

black crows circle,

seagulls chase scraps

Squawk, peck and fight.

Parrots screech.

Kookaburras sing in the dusk.

The sun sets,

quickly.

I start to shiver.

In the quietness of the night and

and the candle-lit picnic table

I hug myself

and simply listen. 


\section{Research statement}

\section{Research background}

In 2015, building on previous research into creativity and memory (Sacks 2006), how writers join fragments of knowledge into new understandings (John-Steiner 1997) and collaborative creative writing (Anderson et al. 2014), two research writing workshops were held to investigate developing collaborative poetry based on personal memories and a writer's sense of place.

\section{Research contribution}

Three collaborative poems were developed and edited. These outputs exemplify how the melding of individual voices offers a dynamism that may not always be achieved by solo writers. Sharing this technique to facilitate both individual and collaborative investigation and writing also resists the sometimes overwhelming nature of working in solitude (Doherty 2009) and the competitive nature of research evaluation (Brien 2007).

\section{Research significance}

This research has resulted in an invited public performance in a publically-funded creative venue (Noosa Regional Gallery 2015) and peer refereed publication in a leading, quality journal of creative writing.

\section{Works cited}

Anderson et al. 2014 'Collaborative scholarly creative writing: two poems' TEXT Special issue 27, at http://www.textjournal.com.au/speciss/issue27/Various.pdf (accessed 9 May 2015)

Brien, DL 2007 'Higher education in the corporate century: choosing collaborative rather than entrepreneurial or competitive models' New Writing 4 (3): 157-70

Doherty AW 2009 The midnight disease: the drive to write, writers block and the creative brain Houghton Mifflin Harcourt, New York

John-Steiner, V 1997 Notebooks of the mind 2nd ed, Oxford UP: New York

Noosa Regional Gallery 2015 'Prose and poems: a poets' breakfast' 19 September, at http://www.noosa.qld.gov.au/whats-on-nrg (accessed 22 September 2015)

Sacks, O 2006 [1985] The man who mistook his wife for a hat and other clinical tales New York: Simon \& Schuster 


\section{University of the Sunshine Coast}

\section{Ross Watkins}

\section{You see now}

\section{Biographical note:}

Ross Watkins is an author, illustrator, editor and academic. His first major publication was The Boy Who Grew Into a Tree (Penguin 2012), and his picture book One Photo (Penguin) is forthcoming mid-2016. Ross is a Lecturer in Creative Writing at the University of the Sunshine Coast.

Keywords:

Creative writing - author/illustrator - illustration - sequence - sequentiality - comics 


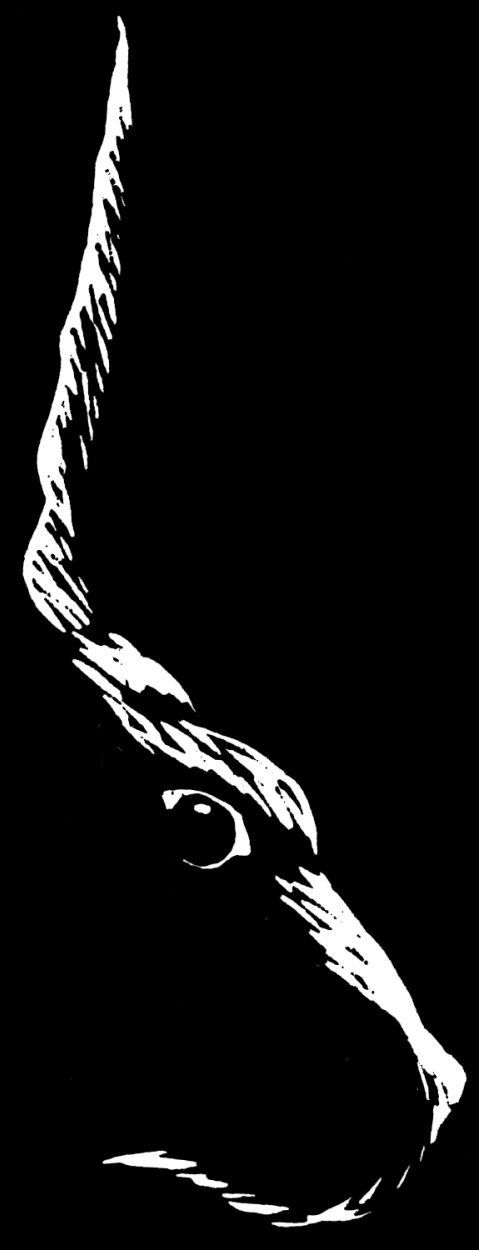

\section{You See Now \\ Ross Watkins}



$\int$ ou see now I know the word motivation, but that don't mean all the itsy bitsy thoughts and things that happen can be explained as some definitive motive. I see it different. People like neatness. People like boxes to keep all their mess and pretend it's neatness. I hear what my brother always says when I get up on top of my box and do what he calls 'intellectualise' about such notions, but I believe that of all the opportunities to explain things in the way they was meant to be explained, fulsome like, this is the one time he'd allow it. Oh yes. But he's not here because of her. 
She made herself known around the same time I saw the dead thing. I got the hankering for a few big mouth beers one night so I stepped out to go get me some. I drank two big mouths on my way back but that isn't necessarily saying much because two don't usually get me seeing things that ain't really there. This thing was there, no doubt about it. I thought it was a small child. I thought it was rolled up in a nice fuzzy blanket. I figured it was thrown from a car window or pushed from out the door because kids around here don't go playing on the road. But anyways it was most certainly clipped by a passing vehicle because there was a patch of dark trailing from a tangle where the inside had busted through to the outside.

I stopped a short way away and my eyes they were fixed. I stayed a while. I sat on the curb. I drank another big mouth. Ideas came to my head. Ideas about that body being there just for me, to show me something I ain't never seen before and so teach me some kind of lesson. I became familiar with that body. I became familiar with its shape as the shape of finality and with that acquaintance I thought it best I take a closer look before doing something about it, like making a phone call. I left my can in the curb and I walked on over to the middle of the road and then and there I saw it for what it really was - a jackrabbit. A big old hare with its guts spread. You might say I was disappointed. You might also say that that disappointment triggered something unknowable which I needed to know. 
She appeared round about the same time. I called her Done Girl. I called her that because my brother was done up on her and eventually she done him over too. Done Girl. When I first saw her they was sitting on my couch with her leg over him and pestering about touching her leg like it was a holy creation. She'd say these things that sounded more like instructions with a question mark tacked on the end just so he didn't think it. Things like: Pass me a cigarette? Issa last one-you go down and get me another pack? My brother isn't exactly a bright boy but he has a fine jaw line and the right slope of nose and just the smirk to make him pleasing to a girl's fancy. I visited him in the clink one time and only one time because seeing him in there made me realise just how naive he truly is and how that place can take a naive boy and make him into a man who knows the grit and grain of what is. So I thought it best to leave that process to take its course. Besides, seeing him in there was a sure way to get me down.

I mean he ain't no blunderbuss, just a little slow on the uptake is all. She was clever enough to pick it and use it to her advantage. And I'm not telling you these things as some kind of justification - trying to make out like she's all bad or whatever and deserving what came. Truth is I never really knew much about her and I'm sure she was an ace chicken in some ways or other so all this iteration isn't about that, and the sooner you get that out of your thinking the sooner you might hear a bit louder what it is I got to say. 


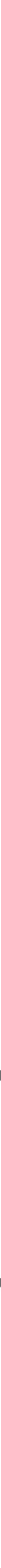


And I didn't do it because she was a girl, neither-gender got nothing to do with it. My decisions was opportunistic. I got no shame in admitting to strategy.

There was this one night I came in late and she was laid out on the couch. She'd had more than a few, with the empty cans clanking around my feet and cigarette butts all over and if I didn't lick my finger and put it under her nose I would've thought she was easy dead. I never seen someone sleep like she was sleeping. She was a slender package so I got on the couch there besides and she moaned something only my brother would understand but I just went mmhmm which was convincing enough for her, half asleep and fully inebriated. I mean I didn't touch her neither, you understand. It was nothing like that. Nothing sordid like. Not then and not when I finally got to see what Done Girl was really made of, when she split open real nice like her chest was nothing more than a neat zip jacket.

Yeah, you seen the photos. I know. The describing words are also exhilarating ain't they?

So as I was saying I got down there besides her and looked at her up close - tiny earring, and the meat of her face come loose with drink and lips droopy and her eyes sunk in and I guess it was these things which made me think of her like she was a stiff. Except she smelled of candy and booze and smoke, not something more body like. Not like something that's got the whiff. 
When me and my brother was itsy bitsy kids we'd often play pretend knives and guns and by God this one time I knocked him clean off his feet and his head clouted the timber of his bed and he went nothing but so quiet I thought I'd truly done him for good. I said his name and shook him and gave his face a hard squeeze I guess out of being afraid. I went to go get our papa and while he was coming in from the yard I screwed my brother's face some more and put my nails in him and he just lay there cold. Course when our papa came in he asked what was all the commotion and plain as day told my brother to stop messing with his patience and he just raised himself from the dead and I could've killed him for real he was so crafty at playing the corpse. I never forget that.

I see plenty of movies and television shows where there's this dead body and people either create it or find it or read its holes like some kind of inverted Braille telling stories of how it came to be that way-its own private and gloomy plot. But the screen puts a distance. The knowledge there's a camera and a camera operator and a microphone and phoney this and phoney that puts a distance so big between what's actual and what's just a stupid bunch of pretend. The more I thought about that fact the less I could watch and the more itchy I came. Because truth is in the seeing. I mean seeing for real. People say that beauty is in the eye of the beholder but I say truth lives in that there place. Beauty just be a part of one's idea of truth. 

And beauty plays its own part in all this because it was her idea of beauty which she was chasing and his idea of beauty which led him to commit to what she was asking - telling, in fact, but he was so in her groove by then he didn't much flinch at that. He just did.

First it was two flowery pink barrettes. She seen them in a store and said to him, You can put those pretty clips in your pocket. From then on her question mark was all together missing and she kept those instructions a' coming. Books and cigarettes and booze and shiny little trinkets and eventually she told him that he was so good at the filch that he could easy make off with some money and they could buy a car and he could drive them interstate and her old ma could go fuck herself and my brother would no longer have to rely on me which she said was getting him blue. Well course my brother knew nothing about what he was doing - I mean he knew what he was doing but he had no idea how to do it so's not to get caught and soon enough he was cuffed and sentenced to the clink. She took off back to her old ma and I never saw her again til that day which brought us to this here circumstance.

You know, after that hare on the road I took to wandering the streets at night hoping to see something likewise curious but all I witnessed was ordinary people going about ordinary business by theyselves. People coming home or setting out, a couple having a cracker of an argument maybe and a Chinese man always with his grocery bag — common responsibilities and private concerns — but it's 
like I got a grain in my eye I couldn't blink out and nothing short of extraordinary was shaking it. I'm talking red eye. I'm talking weepy eye. I'm talking an eye so hot it's boiling to the point that everything becomes suddenly clear. And Done Girl saw me clear as sunny light that last Thursday a' hers.

Now our re-acquaintance was no lucky trick. She'd heard along the vine that my brother was due out on parole so she wrote him, expecting him to come to me for homecoming but course he was provoked into doing some blunt thing to another prisoner so he scored more time. I got her letter and opened it and laughed at the fool she was with her big plans of hitching the highway to meet him. And that very night I had a vision which told me just where her foolish story would end-I mean she looked exactly how she ended up.

Okay so maybe some of the particulars were otherwise but this vision spooked me into knowing what had to be done. Hell, it was already done - set into motion like some vehicle of deliverance. And I'm not trying to give the idea of cosmic perception and intervention here- that's not it at all. No doubt me reading her letter jogged my thinking about her dead drunk on the couch that time and the big old hare and everything so with a little strategy I set about making the vision a reality.

The arrangements was simple: I knew an old guy who lived her way and was more than willing to accept a few bucks just to drive 

back and forth till he picked her up then drop her at the roadhouse. You shoulda seen her face when I pulled in next to the phone booth... She hung straight up and was finally all questions, proper questions, first I ever heard rolling off her silly tongue: How come you here? You takin me to him or what? You mind if I smoke long the way? I tell you I was grinning like I come direct from the loony bin.

All in all she did well - was more than cooperative, reaching under her seat when I asked her to. I mean I was polite and everything. She said all the things you expect someone to say in such a situation, although I told her it was evident she seen too much television to make her original. Is a difficult thing but still a shame in her final moments the only words she could spout sounded like some phoney movie script but I didn't get hooked up on that. I wasn't so fixed on the way she sounded.

She did look a picture.

So you see now what they want to hear is a motive summed up in some neat sentence. They want a neat box, I know it. But not everything comes in boxes and some things just ain't the right fit for a box of any make. And you can write that there on your tidy paper and you can bring your gavel down upon it and decide whatever but you ain't ever capable of closing my eye to what it's seen. No. Because there's a knowledge comes with seeing and witnessing with the raw eye that no amount of imagining can equal. Oh yes. 


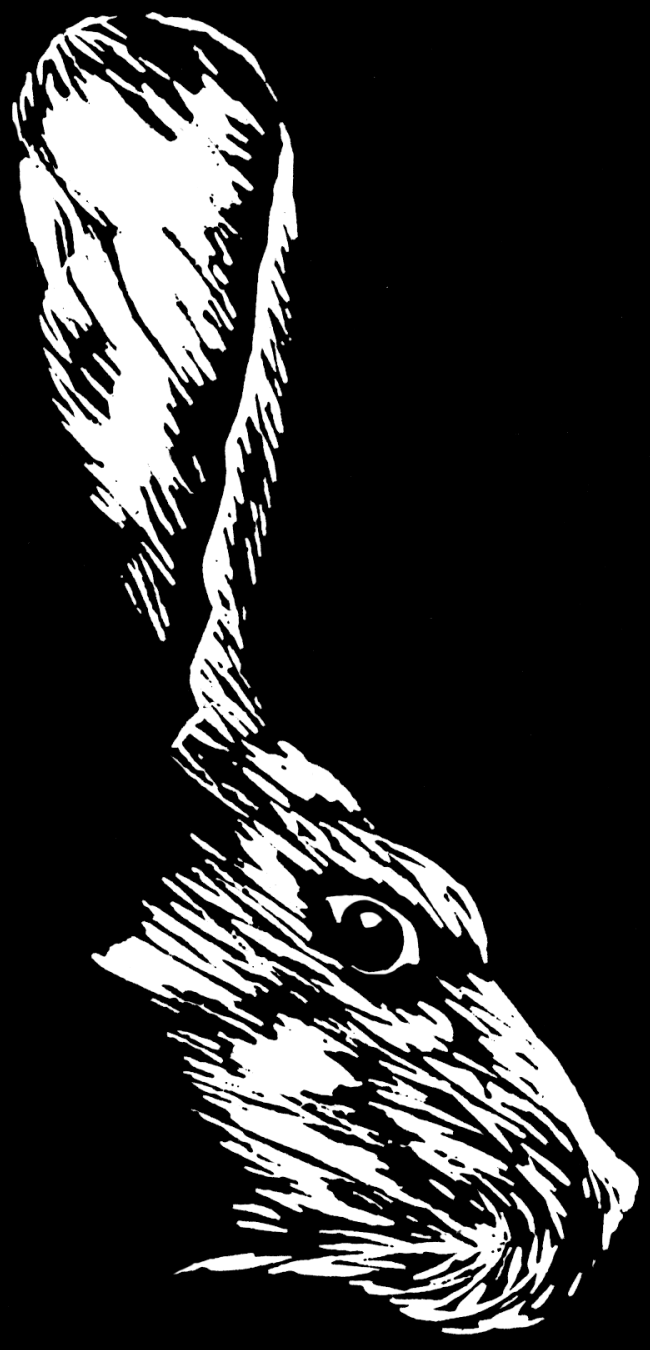




\section{Research statement}

\section{Research background}

Furthering the work of McCloud (1993) on the act of closure within comic panel sequences, Lefevre argues that when 'various pictures are grouped together in a series or sequence, the viewer or reader is prompted to look for relations among them', and 'interpreters will almost automatically look for some minimal coherence or narrative' (2011: 26). Whitlock describes this act as 'observing the parts but perceiving the whole' (2006: 969). You see now experiments with the potential parameters and effects when sequencing visual elements within a prose short story.

\section{Research contribution}

You see now prompts readers to actively interpret the illustrations via symbolic connection to abstract themes and plot ideas encountered in the prose - illustrations depicting an act of predation tell a counter-narrative, while the hare illustrations 'bookend' the emergence of the narrator's desire to progress from trauma witness to trauma perpetrator. Rather than 'filling gaps' within the prose, the illustrations raise further narrative complexities via contiguity. Unlike comic sequences, the illustrations both signify and create breaks/silences from the prose, augmenting tone and suspense.

\section{Research significance}

You see now exemplifies and extends the methodologies explored in my previous TEXT article (April 2015), which traces the formative processes involved in authoring/illustrating 'Truth Is', the illustrated novel from which You see now is derived. As there are presently few articles within TEXT which speak to the concerns and interests of author/illustrators, this research represents and contributes to an emerging area of speciality within the journal.

\section{Works cited}

Lefevre, Pascal 2011 'Some medium-specific qualities of graphic sequences', SubStance \#124 40(1): $14-33$

McCloud, Scott 1993 Understanding comics, Canada: Paradox Press

Whitlock, Gillian 2006 'Autographics: the seeing "I" of the comics', Modern Fiction Studies 52(4): 965-79 